\title{
Ischemia/Reperfusion Injury Revisited: An Overview of the Latest Pharmacological Strategies
}

\author{
Ricardo O. S. Soares ${ }^{1}$ (D), Daniele M. Losada ${ }^{2}$, Maria C. Jordani ${ }^{3}$, Paulo Évora ${ }^{3,4}$ and \\ Orlando Castro-e-Silva ${ }^{3,4, *}$ \\ 1 Marília Medical School, 17519-030 Marília, Brazil; med.ricardosoares@gmail.com \\ 2 Department of Anatomic Pathology, Faculty of Medical Sciences, University of Campinas, \\ 13083-970 Campinas, Brazil; danielelosada@hotmail.com \\ 3 Department of Surgery \& Anatomy, Ribeirão Preto Medical School, University of São Paulo, \\ 14049-900 Ribeirão Preto, Brazil; mceciliajordani@gmail.com (M.C.J.); prbevora@fmrp.usp.br (P.É.) \\ 4 Department of Gastroenterology, São Paulo Medical School, University of São Paulo, \\ 01246-903 São Paulo, Brazil \\ * Correspondence: orlando@fmrp.usp.br
}

Received: 12 September 2019; Accepted: 8 October 2019; Published: 11 October 2019

\begin{abstract}
Ischemia/reperfusion injury (IRI) permeates a variety of diseases and is a ubiquitous concern in every transplantation proceeding, from whole organs to modest grafts. Given its significance, efforts to evade the damaging effects of both ischemia and reperfusion are abundant in the literature and they consist of several strategies, such as applying pre-ischemic conditioning protocols, improving protection from preservation solutions, thus providing extended cold ischemia time and so on. In this review, we describe many of the latest pharmacological approaches that have been proven effective against IRI, while also revisiting well-established concepts and presenting recent pathophysiological findings in this ever-expanding field. A plethora of promising protocols has emerged in the last few years. They have been showing exciting results regarding protection against IRI by employing drugs that engage several strategies, such as modulating cell-surviving pathways, evading oxidative damage, physically protecting cell membrane integrity, and enhancing cell energetics.
\end{abstract}

Keywords: ischemia/reperfusion injury; pro-survival pathways; mitochondria; reactive oxygen species; inflammation; RISK pathway; SAFE pathway; cyclic guanosine $3^{\prime}, 5^{\prime}$-monophosphate/Protein Kinase G pathway

\section{Introduction}

In routine clinical practice, dealing with tissue ischemia frequently also means dealing with reperfusion and its distinctive associated injury. Although the direct proportionality between IRI intensity and the practiced ischemic period is well-established, prompt reperfusion is not always practicable. Either regarding pathogenic conditions or transplantation-derived tissue anoxia, several factors contribute to a poor prognosis, such as the difficulty to induce a swift medical response, the timeconsuming task of organ harvesting or even prolonged graft conditioning. Even in a hypothetical scenario with a minimal ischemic period, likely reperfusion would still cause some cell stress.

Ischemia/reperfusion injury (IRI) is a term used to describe functional and structural changes that become apparent during the restoration of the blood flow after a period of ischemia. In addition to the reversal of ischemia, the repair of blood flow can result in potentially very harmful effects such as necrosis of irreversibly damaged cells, marked cell swelling and nonuniform flow restoration to all portions of the tissue. This chaotic restoration of the tissue flow, the reflow phenomenon, is the result of a vicious cycle of vascular, endothelial and mitochondrial dysfunction, with reduced local 
perfusion, intense dysfunctional changes, edema, and many more implications. The occurrence of metabolic disorders during ischemia or tissue hypoxia are currently well established, but clinical and experimental evidence shows that the significant events leading to cell and tissue dysfunctions are mostly related to the subsequent reperfusion.

Much has been studied in the last 40 years to define the pathogenesis of reperfusion injury, and current therapeutic theories try to integrate numerous considerations such as the impairment of endothelium relaxation observed after ischemia/reperfusion, the limitation of the reperfusion injury by scavenging of free-radicals, and blockade of neutrophil activation and adhesion [1-4].

Interestingly, remarkable advances in the field of preservation preceding-or treatment following- $\mathrm{I} / \mathrm{R}$ insult, have been made not only by efforts to the design of new drugs but also by exploiting the pleiotropic pharmacological properties of well-known compounds. Although the importance of the former is unquestionable, the latter bears clear advantages regarding the potential to evade time-consuming safety investigations and to enable more agile development of therapies. Unfortunately, albeit many studies have shown promising results, most of them are restricted to pre-clinical phases and are seldom viable for undergoing proof-of-concept and large human clinical trials [5]. Therefore, it is imperative for IRI research to continually keep up with the current state of protecting drugs so that efforts in the translational research could be maximized in order to transform this knowledge available as novel human therapeutics.

In the first part of this review, we present the current knowledge about the pathophysiology of the IRI and some aspects of its systemic effects. Then we provide an outlook of the latest findings regarding pro-survival pathways and the latest pharmacological efforts that have been showing successful levels of protection against the deleterious effects of $\mathrm{I} / \mathrm{R}$ in experimental settings.

\section{Pathophysiology of IRI}

The ischemia-reperfusion injury (IRI) involves pathophysiological mechanisms with local and systemic effects. This process takes place fundamentally in two stages: firstly during ischemia, the main factor at play is cell energy depletion and, secondly during reperfusion, the interplay of oxidative and microcirculatory stress, along with inflammation and apoptosis [6-8]. A summary of the main functional and structural changes secondary to these processes is given below.

\subsection{Ischemic Period: Hypoxic Injury and Preparation for Reperfusion}

Cell sensitivity to hypoxic aggression varies among distinct types of cell, but cellular deterioration is always proportional to the ischemia persistence. The alterations in the cell metabolism consist essentially of a dual nature: 1) reversible (functional or ultra-structural changes that can be visualized by electron microscopy), or 2) irreversible (structural changes that are possible to be identified by light microscopy) culminating with cell death through the mechanisms of apoptosis or coagulative necrosis [9]. Table 1 summarizes the ultrastructural findings regarding reversible and irreversible cell injury.

Table 1. Ultrastructural findings regarding reversible and irreversible cell injury (adapted from [9]).

\begin{tabular}{ccc}
\hline Ultrastructural Alteration & Reversible Injury & Irreversible Injury \\
\hline Plasma membrane & $\begin{array}{c}\text { formation of bubbles, reduction, } \\
\text { and distortion of microvilli, } \\
\text { appearance of myelin figures and } \\
\text { loosening of intracellular bonds }\end{array}$ & $\begin{array}{c}\text { evident discontinuity of plasma membranes } \\
\text { and organelles }\end{array}$ \\
Mitochondrial & $\begin{array}{c}\text { edema, rarefaction, and } \\
\text { appearance of amorphous } \\
\text { densities rich in phospholipids }\end{array}$ & $\begin{array}{c}\text { dilatation of mitochondria with formation of } \\
\text { amorphous densities, intracytoplasmic myelin } \\
\text { figures and cotton-like material (denatured proteins) }\end{array}$ \\
\hline Nuclear & $\begin{array}{c}\text { kisintegration of granular and } \\
\text { fibrillar elements }\end{array}$ & $\begin{array}{c}\text { karyolis (DNase activity), pyknosis (shrinking of } \\
\text { the nucleus and increased basophilia), karyorrhexis } \\
\text { (nuclear fragmentation) }\end{array}$ \\
\hline
\end{tabular}


Edema is the first ultra-structural cell manifestation. This morphological change is expressed macroscopically by paleness and increases in turgor and organ weight. Microscopic examination shows small clear vacuoles in the cytoplasm as distended segments of the endoplasmic reticulum, characterizing the vacuolar degeneration [9]. Ischemic injury is associated with systemic inflammation due to cytokine production and increased expression of adhesion molecules by hypoxic parenchymal and endothelial cells. It is set the background to the next stage: reperfusion.

\subsection{Reperfusion Injury: the Superlative Damage}

The initial phase of reperfusion starts after the first minutes of ischemia and lasts for up to $6 \mathrm{~h}$ [7]. A minimum period of ischemia is required to take place before the reperfusion injury begins to take place in a progressively aggressive fashion. Evidently, these thresholds vary significantly among different species and tissues. The critical safe ischemic period has been defined as $20-25 \mathrm{~min}$ in the mouse myocardium [10], though this limit may very well be higher before unrepairable damage occurs. In humans, the onset of oxidative damage has not yet been clearly defined. However, it has been established that significant myocardial tissue salvage and functional recovery can occur up to $9 \mathrm{~h}$ after coronary occlusion [11]. Likewise, pharmacological or surgical salvage of dog myocardium can be safely obtained with warm ischemia safely up to $3 \mathrm{~h}$ after occlusion [12].

Systemically, reperfusion injury initially mobilizes neutrophils via chemotaxis and endothelial adherence, $\mathrm{CD}^{+} \mathrm{T}$ lymphocytes and circulating platelets in the vascular space. Neutrophils stimulate the production of reactive oxygen species (ROS), tumor necrosis factor alpha (TNF- $\alpha$ ) and local inflammatory mediators aggravating tissue damage [13]. $\mathrm{CD}^{+} \mathrm{T}$ lymphocytes produce macrophage-stimulating factors, interferon-gamma, and TNF- $\beta$, which amplify the activation of local macrophage cells and the release of cytokines [7]. Furthermore, re-oxygenation increases the amount of oxygen free radicals in the parenchymal, endothelial, and lymphocytic cells that infiltrate the lesion. Superoxide anions are produced as a result of the incomplete reduction of oxygen by the damaged mitochondria and due to the action of neutrophils, endothelial cells or parenchymal cells. These processes result in the accumulation of free radicals, unstable molecules that destabilize inorganic and organic chemicals leading to cell injury $[7,9,14]$.

Systemically, the increase in the levels of circulating ROS and pro-inflammatory factors induces oxidative stress and an increase of endothelial adhesion molecules, in distant organs, respectively [7]. Besides, nitric oxide (NO) levels are reduced, and there is an imbalance between the production of endothelin-1 and NO by NO synthase (NOS), leading to vasoconstriction that, added to the increased expression of adhesion molecules, facilitates the entrapment of platelets and neutrophils in local vascular structures. Microcirculatory insufficiency leads to prolonged ischemia and aggravated necrosis, macrophage cell activation, and the cyclic release of ROS and inflammatory cytokines [7]. Two particular subjects that deserve special attention when reviewing IRI are the pivotal roles of the endothelium and the mitochondria.

\subsection{The Ever-Evolving Role of Mitochondria in IRI}

Although many cellular compartments are intimately linked to the pathophysiology of IRI (i.e., the endoplasmic reticulum is able to sense oxidative stress, maintain calcium homeostasis and respond to IRI with apoptosis [15-17]), to discuss all of them would be beyond the scope of this review. Here we focus on the mitochondria because of its central role on the cell energetics, a fact that renders it a pervasive standing as a pharmacological target. The advent of oxygen depletion during ischemia affects the mitochondrial coupling directly, causing inhibition of electron transport in the mitochondrial respiratory chain and decrease in ATP levels. This condition leads to failure of the $\mathrm{Na}^{+} / \mathrm{K}^{+}$pump, membrane depolarization, and intracellular $\mathrm{Ca}^{2+}$ accumulation: a typical scenario that links the mitochondrial respiratory activity and the mechanism of IRI. Our group recently demonstrated significant inhibition of electron transport through the respiratory chain in the rat liver caused by a single cycle of I/R [18]. 
The respiratory perturbations are further associated with lactic acidosis due to anaerobic metabolism, activation of proteases, lipases, phospholipases, and ATPases, all contributing to enhanced injury. The intracellular increase of $\mathrm{Ca}^{2+}$ is related to the intensification of its influx into the mitochondria, which, being associated with the accumulation of ADP, AMP, and phosphate resulting from ATP hydrolysis, causes loss of the impermeability of the internal mitochondrial membrane to solutes that are not endowed with specific transport systems. Mitochondrial dysfunction arises and the apoptotic pathway is engaged $[7,19]$. The transition of mitochondrial membrane permeability is a process mediated by the opening of a nonspecific channel called the permeability transition pore (mPTP). This process is characterized by mitochondrial swelling and is induced by a threshold of $\left[\mathrm{Ca}^{2+}\right]$, which is significantly reduced by ROS build-up [18]. These phenomena have been consistently associated with cell death resulting from a variety of pathological conditions, including IRI [20,21].

During reperfusion, the reestablishment of the blood flow associated with the intracellular increase of $\mathrm{Ca}^{2+}$ leads to the generation of ROS by several metabolic pathways. Concomitantly, there is the activation of the inflammatory response, whereby cellular adhesion receptors are activated and neutrophils migrate through the endothelial wall into the tissue parenchyma releasing cytotoxic mediators such as tumor necrosis factor (TNF), interleukins (ILs), and NOS and directly or indirectly leading to the production of highly reactive species such as superoxide anion, hydrogen peroxide and peroxynitrite [20-24]. Mitochondria are critical intracellular sources of ROS: a fraction of 3\% to $5 \%$ of the $\mathrm{O}_{2}$ available for the respiratory chain undergoes incomplete reduction generating these by-products. In certain pathophysiological conditions, despite the presence of potent endogenous antioxidant mechanisms, it is possible that the production of oxidants exceeds these mechanisms, creating an imbalance situation called oxidative stress [21].

The mitochondria, however, are not devoid of defense mechanisms, and autophagy stands as a crucial modulating process, that is also responsible for cellular recycling. It contributes with damaged protein and organelle degradation via a complex and dynamic multi-step process regulated by several signaling pathways, including Beclin-1/class III phosphatidylinositol-3 kinase (PI3K), AMPK/mammalian target of rapamycin (mTOR), and PI3K/Akt/mTOR pathways [25]. Three types of autophagy, macroautophagy, microautophagy, and chaperone-mediated autophagy differ in the way by which unnecessary components are delivered into lysosomes for final degradation. The selective clearance of damaged mitochondria by the mechanism of autophagy is termed as "mitophagy" [26,27]. During the ischemic insult, the decreased level of ATP activates adenosine monophosphate-activated protein kinase (AMPK) which, in turn, regulates the induction of autophagy via Unc-51-like kinase 1 (ULK1) modifications in direct or indirect pathways. The indirect ULK1 modification pathway occurs through AMPK-mTORC1. During the initial phase of ischemia, the activation of autophagy functions maintains energy balance through recovering ATP generation and plays a protective role preventing damaged mitochondrial from releasing cytotoxic substances and therefore attenuating apoptosis [26,27]. Reperfusion can also contribute to the induction of autophagy [28]. However, high levels or long-term upregulation of autophagy can lead to excessive degradation of essential proteins and organelles culminating with autophagic cell death. This process is morphologically identified at electron microscope by abundant vacuoles in the cytoplasm [25]. Whether autophagy is beneficial or detrimental is controversial, and many factors must be considered in this analysis, including methods for assessing it, timely intervention and experimental models and their variability [27].

The mitochondrial respiratory complexes (I, II, III, and IV) are an important subject in this review and will be thoroughly discussed in Section 4.5 . For now, at the risk of oversimplification, we may state that under I/R conditions, the complexes may face an essential mitochondrial redox balance that ultimately leads to regulation of ROS production. In order to better characterize this process, two variables are essential to be defined. The redox driving force $\left(\Delta \mathrm{E}_{\mathrm{H}}\right)$ represents the reduction potential between the NADH and the CoQ-pool through the complex I, and the proton-motive force $(\Delta \mathrm{p})$ is the force generated by the proton gradient across the inner mitochondrial membrane that powers the generation of ATP [29]. Let us now describe the whole process according to the three 
fundamental steps that involve IRI: (1) physiological conditions, followed by (2) ischemic hypoxia and then (3) reperfusion. Under physiological conditions, low reduced to oxidized nicotinamide adenine dinucleotide ratio (NADH:NAD ${ }^{+}$) guarantees enough redox driving force to maintain the adequate membrane potential required to perform ATP synthesis $\left(\Delta \mathrm{E}_{\mathrm{H}}>\Delta \mathrm{p}\right)$. When hypoxia is applied, high NADH:NAD ${ }^{+}$ratio develops and reduces the CoQ-pool via complex I, which is responsible for both mitochondrial succinate accumulation via complex II and for the loss of membrane potential, inverting the $\Delta \mathrm{p}<\Delta \mathrm{E}_{\mathrm{H}}$ relationship and hence halting ATP synthesis [29,30]. Finally, when the reintroduced $\mathrm{O}_{2}$ meets a reduced CoQ-pool upon reperfusion, the complexes III and IV resume proton pumping and further reduce $\mathrm{CoQ}$, keeping and intensifying the inverted relationship created under ischemia $\left(\Delta \mathrm{p}<\Delta \mathrm{E}_{\mathrm{H}}\right)$. At last, but not least, the $\mathrm{O}_{2}$ is converted to $\mathrm{O}_{2}{ }^{\bullet-}$ by the reduced flavin mononucleotide (FMN) prosthetic group of complex I, creating a ROS burst which may lead to cell death [31,32].

The continuous progress in the unveiling of all of these events is exciting, for, with them, more therapeutic possibilities arise. Chouchani et al. already demonstrated that pharmacological inhibition of complex II with dimethyl-malonate decreases the accumulation of ischemic succinate and attenuates IRI in murine models of heart attack and stroke [30].

Progress always requires pushing the frontiers of knowledge, and in this context, few eukaryotic structures have drawn so much attention lately as the mitochondria. Substantial evidence now tells us that not all mitochondria in our bodies are the same. They are divided into subpopulations that vary structurally and functionally to such an extent that it is possible to observe distinctions even within the very same tissue, as explained by Hollander et al. regarding the categorization of cardiac mitochondria into subsarcolemmal (SSM) and interfibrillar types (IFM) [33]. Furthermore, the notion that mitochondrial metabolism is related both to age and sex has been demonstrated empirically several times based on different levels of sensitivity to $\mathrm{Ca}^{2+}$ [34], mitochondrial permeability transition pore (mPTP) responsiveness [35] and myocardial protection in IRI [36]. These findings should definitely be considered during the development/evaluation of therapeutic approaches to I/R-linked diseases and surgical procedures.

\subsection{G-Proteins and Endothelium Interplay in IRI}

NO release can occur by different pathways involving G-proteins, which are responsible for the mediation of the inhibitory effects of receptors in the adenylate cyclase and guanylate cyclase pathways. An early stage of most of the responses mediated by receptors includes the activation of G-proteins in the cell membrane, which is the target of the modulation of a variety of intracellular events. The role of G-proteins in the pathophysiology of vasospasm after global ischemia and reperfusion is still a matter of investigation.

The crucial role of G-proteins in transmembrane signal transduction has been emphasized by the rapid expansion of the list of receptors and effector molecules, which are coupled by G-proteins. These proteins are equalized to allow discrimination and diversification of cellular signals in the cytosolic medium [1-4]. The use of an evolutionarily preserved "GTPase watch" by G-proteins implies the knowledge of the fundamental biological role that these proteins may play. The understanding of this altered expression or function of G-proteins in human diseases is a subject of high interest. It is not surprising that the deficiency of expression or modified forms of these essential proteins may lead to global or restricted metabolic disorders, depending on the distribution and role of G-proteins.

Ischemic heart disease stands out as a primary worldwide cause of death [37]. Nowadays, acute myocardial ischemia treatment is based on reperfusion therapy using fibrinolytic drugs or coronary angioplasty. Coronary reperfusion is mandatory for the survival of myocardial tissue, and the identification of endogenous signaling pathways [38] to the ischemic heart could lead to novel pharmacotherapy investigations for the improvement of the reperfusion procedures and the receding of cardiac injury in patients with ischemic heart disease.

In this milieu, G-protein-coupled receptors play essential roles since they can be activated by neurotransmitters or endogenous hormones on signaling pathways that have cardioprotective effects 
on the ischemic heart [39]. Gai signaling suppresses ischemia-induced apoptosis and enhances the post-ischemic recovery of contractile function V [40-42]. Also, the control of $\mathrm{G}$ protein signaling (RGS) suppresses $\mathrm{G} \alpha$ i signaling by increasing the rate of hydrolysis of $\mathrm{G} \alpha$-bound GTP [41,43]. However, it is unknown which RGS proteins modulate this cardiac response to ischemia. RGS6 is one of only a few regulators of $G$ protein signaling (RGS) that have been identified at the protein level in the ventricle $[44,45]$.

Based on these literature data, Rorabaugh et al. examined the effect of RGS6 deletion on myocardial sensitivity to an ischemic insult. These authors anticipated that the RGS6 deletion would result in a cardioprotective phenotype similar to that observed in mice expressing RGS-insensitive Gai2, but, surprisingly, they found that deletion of RGS6 worsens the ischemic injury, indicating that RGS6 expression is cardioprotective [46].

The participation of G-proteins in the heart IRI was documented in a comparative study of vascular relaxation induced by sodium fluoride, which produces biphasic responses in human, bovine, and porcine coronary arteries, causing an endothelium-dependent relaxation and an endothelium-independent contraction. G-protein dysfunction in the endothelium has also been postulated to be responsible for the endothelial dysfunction under conditions of endothelial cell regeneration after injury, atherosclerosis, and coronary vasospasm (Figure 1). Myocardial ischemia and reperfusion selectively impair receptor-mediated NO release. However, the ability of the endothelial cell to produce NO or generate endothelium-dependent relaxation to non-nitric oxide-dependent agonists remains intact $[47,48]$.

In summary, we may safely state that (1) endothelial cells maintain their capacity to release NO based on their ability to receive the transduction signal through the membrane, (2) G-proteins have a fundamental role in the signal transduction, and (3) this paradigm is extended to all vasotonic cardiovascular diseases that coexist with platelet dysfunction. These data would be highly relevant in the development of G-protein-targeting drugs.

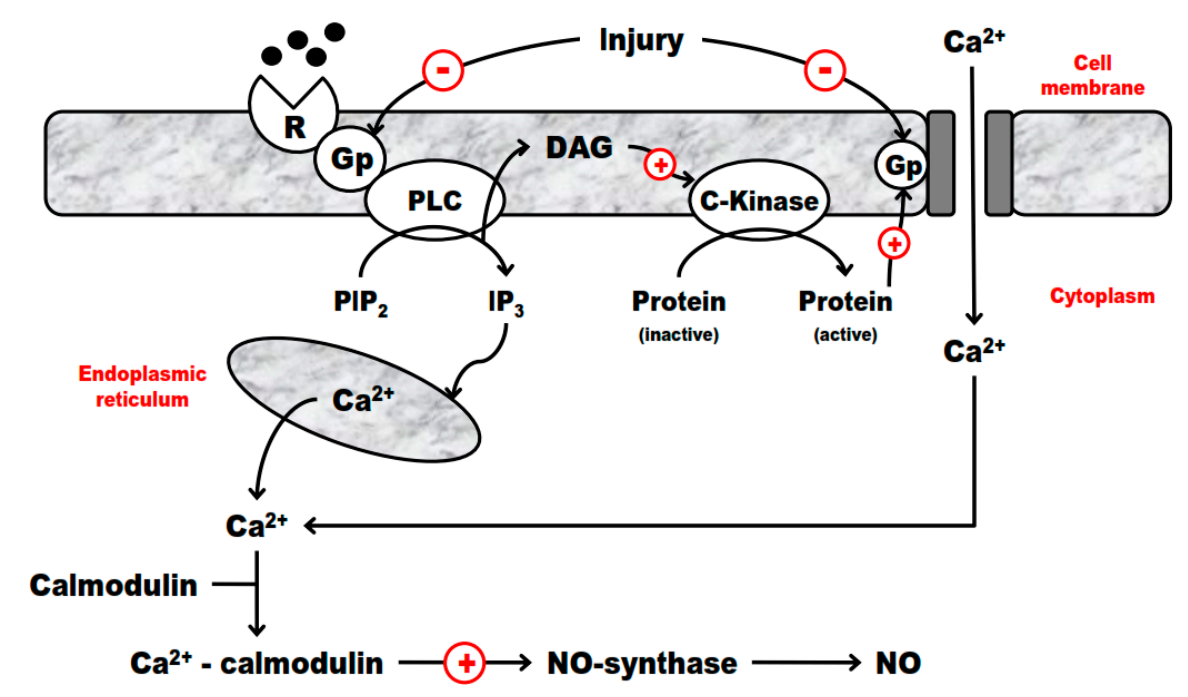

Figure 1. Proposed mechanism of impaired endothelium-dependent vasodilation after coronary reperfusion injury. Upon reperfusion, free radicals from a variety of sources induce injury to G-proteins $(\mathrm{Gp})$ that link intracellular processes. Two possible sites of injury in the present model are the signal transduction pathway between the cell receptor (R) and phospholipase C (PLC) and the pathway that activates the influx of extracellular calcium for sustained production of endothelium-derived nitric oxide $(\mathrm{NO})$. (DAG = diacylglycerol, $\mathrm{IP}_{3}=$ inositol trisphosphate, $\mathrm{PIP}_{2}=$ phosphatidylinositol 4,5-biphosphate, $(-)=$ inhibits, $(+)=$ stimulates.) (Adapted from Evora et al. [4]). 


\section{Systemic Susceptibility to IRI}

All oxygenated tissues are subjected to hypoxia and, therefore, IRI. Such an obvious statement is intentionally placed here to enforce the idea that IRI is of primary systemically importance. Reports of IRI have been attributed to, among others, the heart [49], liver [50,51], kidney [52], skin [53], lungs [54,55], muscles [56,57], eyes [58,59], brain [60], blood vessels [61,62], and mesentery [63]. Since the physiopathology of IRI is mostly the same in these organs, here we focus mostly on three representative organs: the heart, kidney, and liver. Endothelial dysfunction in cardiogenic shock is still IRI open discussion. The systemic inflammatory response (SIRS), complement activation, the release of inflammatory cytokines, expression of inducible NO synthase (iNOS), and inappropriate vasodilation should play an essential role in the genesis of the cardiogenic shock but also in its evolution. These pathophysiological aspects amplified the paradigm of cardiogenic shock complicating acute myocardial infarction (AMI), suggesting new interpretations and therapies.

A clinical update published by Hochman [64] focused on "broadening the paradigm" of cardiogenic shock as a complication of AMI. The systemic inflammatory response (SIRS), complement activation, inflammatory cytokine release, iNOS expression, and vasodilation not only may play a vital role in the genesis of the shock but also in its evolution. New pathophysiological interpretations have been suggested, and therapies based on vasoplegia caused by the increased iNOS expression, such as that used in human patients by Cotter et al., are now in advanced stage [65].

Methylene blue (MB) has been recognized as a guanylate-cyclase inhibitor capable of abolishing cyclic GMP-dependent vascular smooth muscle relaxation without interfering with NO synthesis and without producing tissue necrosis. Thus, methylene blue could be a therapeutic option, not yet tested for vasoplegia related to cardiogenic shock.

The liver IRI has been extensively investigated once the organ may is submitted to ischemia in surgery for partial hepatectomy and liver transplantation. In all cases ischemia is followed by reperfusion and, even though it is essential to reestablish tissue function, reperfusion in the liver usually causes more severe damage than ischemia in proportion to the same period [66].

Ischemia may be disguised as a rather tolerable event, however, as discussed in Section 2, it works as a trigger for the production of molecules that are essential for the induction of reperfusion injury. During the ischemia, hypoxia with a loss of oxidative phosphorylation and accumulation of ADP, AMP, adenosine, inosine, and hypoxanthine resulting from anaerobic hydrolysis of ATP molecule associated with the intracellular influx of $\mathrm{Ca}^{2+}$, leads to an increase in the amount of xanthine oxidase in the liver cell. This increase is due both to the accumulation of these substrates and to the proteolytic conversion of xanthine dehydrogenase to xanthine oxidase $[67,68]$. At the same time, there is an increase in the production of NADPH oxidase, due to oxidation of NADH dehydrogenase, both leading to the production of superoxide anion. Upon re-oxygenation, a burst of superoxide radicals and other types of ROS can occur, inducing oxidative stress to the liver as well as to distant organs $[7,69]$. The reduced ATP generation during hypoxia, associated with immediate reperfusion leads to the cell membrane depolarization due to the disturbance of $\mathrm{Na}^{+} / \mathrm{K}^{+} /$ATPase function, causing cellular swelling $[7,70]$.

Besides the metabolic disorder and the oxidative stress caused by the high concentration of reactive oxygen species, there is involvement of local inflammatory response. Damage-associated molecular patterns (DAMPs) that are released by injured hepatic tissue during ischemia, act on Toll-like receptors present on cells of the immune system, mainly in the Kupffer cells, thereby releasing even further ROS as well as several pro-inflammatory cytokines such as tumor necrosis factor (TNF- $\alpha$ ), interleukin-1 $\beta$ (IL-1 $\beta)$, interferon-gamma (INF- $\gamma$ ), among others [71,72]. This excessive inflammatory response is characterized by activation and migration of neutrophil, $\mathrm{CD} 4^{+} \mathrm{T}$ lymphocytes, and platelets into the liver.

Adhesion molecules such as intracellular cell adhesion molecule (ICAM) and vascular cell adhesion molecule (VCAM) are expressed in the hepatocytes and endothelial cells. These cells are trapped in the constricted and narrowed sinusoids and result in potentiation of the inflammatory injury and microvasculature failure $[7,73]$. In addition, the levels of $\mathrm{NO}$ are reduced and, an imbalance between 
endothelin-1 and NO production from NO-synthase arises. Those events facilitate vasoconstriction of sinusoids [7,74]. All of these factors aggravate ischemia and potentially extend hypoxia effects in the liver. In a vicious cycle, they further activate the Kupffer cells, generates more cytokines and ROS, causing an exacerbated inflammatory response with more reactive oxygen and nitrogen species and, ultimately leading to cell death.

The investigation of cellular biomarkers released in plasma after tissue injury is gaining more interest regarding the management of patients with tissue injury. Technological improvements and the development of more accurate tests have permitted the analysis of such proteins with rapid results [75]. Liver fatty acid-binding proteins (L-FABP) have been demonstrated to be potential biomarkers for liver injury. Considering the hepatocytes are in close contact with the vasculature, L-FABP can be quickly released from damaged hepatocytes into the vascular system since small cytoplasmic proteins diffuse earlier than larger proteins into the vascular system after cell injury [76]. Elevated plasma levels of L-FABP have been associated with liver transplant rejection and are considered to be biomarkers of acute and chronic hepatitis and cirrhosis [75,77].

IRI is frequent after liver transplantation and significantly predisposes patients to graft dysfunction, with an increased risk of morbidity and mortality [78]. Pelsers et al. [75] investigated L-FABP release following hepatocellular injury due to rejection in a group of liver transplant recipients who had episodes of acute hepatocellular rejection during their post-transplantation stay in the hospital. They showed that L-FABP rises significantly during all rejection periods and can be detected in plasma earlier than aminotransferase (ALT), thus representing a more sensitive marker. ALT and aspartate aminotransferase (AST) are plasma markers of acute hepatocellular injury most commonly used to investigate the presence and monitor the progress of liver disease [79]. Although ALT can be measured very quickly and cost-effectively on a routine clinical basis, its plasma concentration correlates with cell damage rather slowly, unlike L-FABP, which is relatively a more sensitive biomarker for liver injury [80].

An additional advantage of using L-FABP instead of AST is its fast renal clearance, resulting in a shorter half-life ( $<4-5 \mathrm{~h}$ ) compared to AST (20-36 h). Therefore, plasma levels of L-FABP after reperfusion more directly reflect the damage of the graft [81].

Since the liver is subject to ischemic damage during the period from donor death to cessation, transport, and transplantation, some tissue injury will inevitably occur. Therefore, care must be employed when using only biochemical markers directly after transplantation. Besides its potential role as an injury marker, Wang et al. [82] demonstrated in vitro the potential of L-FABP to reduce oxidative stress in hypoxia and re-oxygenation. The reduction was proportional to the L-FABP expression, suggesting that this is a strong endogenous antioxidant that could be targeted through appropriate pharmacological treatment in order to minimize cellular damage after I/R.

Acute kidney injury frequently occurs in patients with acute liver failure during the postoperative period after major liver resection or liver transplantation. However, the pathophysiology of acute kidney injury associated with liver IRI has not been fully elucidated $[7,21]$.

Portal hypertension resulting from portal vein occlusion, common to various techniques during hepatic surgery, seems to be the initial event of the injury. Portal hypertension induces splenic vasodilatation and consequently intra-renal vasoconstriction and activation of the renin-angiotensin system. This activation can cause a severe reduction of glomerular filtration rate leading to renal tubular necrosis and renal dysfunction [83]. Besides that, the increased release of pro-inflammatory cytokines and transcription factors such as interleukin (IL)- 6 and tumor necrosis factor-alpha (TNF- $\alpha$ ) from the liver may promote inflammatory changes in the kidney after liver ischemia-reperfusion. The activation of Kupffer cells plays an important role in the production and release of cytokines [83,84]. These proinflammatory factors can stimulate endothelial adhesion molecules such as E-selectin, $P$-selectin and (ICAM)-1, promoting leukocyte recruitment and extravasation into the renal interstitium [85]. In this respect, the integrity of the endothelial barrier is pivotal in the protection of acute kidney injury [84]. 
Another mechanism that could lead to the development of acute kidney injury is damage to the actin cytoskeleton, leading to renal tubular and endothelial apoptosis [86].

The oxidative stress is also critical to the induction of acute kidney injury by liver ischemiareperfusion. Activated neutrophils release reactive oxygen species, enzymes, and cytokines, causing direct renal injury. In addition, the recruitment of monocytes and macrophages aggravates the oxidative injury [87]. The imbalance between the production of ROS and antioxidant mechanisms is showed by the increase in renal malondialdehyde (MDA) levels and the decrease both in superoxide dismutase and catalase activities. Studies have shown that the administration of oxidants seems to have a beneficial effect via the glutathione system in addition to reducing the MDA levels (Section 4). The administration of free radical scavengers has also proved to be effective in hepatic ischemic preconditioning, thus protecting against acute kidney injury. High ROS concentrations induce tissue injury during reperfusion after prolonged ischemia, while moderate ROS are important and can mimicry ischemic preconditioning [88,89]. Endogenous hydrogen sulfide $\left(\mathrm{H}_{2} \mathrm{~S}\right.$, further discussed ahead) has also proved to attenuate the lipid peroxidation and inflammatory events by reducing MDA levels, nuclear factor- $\mathrm{kB}(\mathrm{NF}-\mathrm{\kappa B})$ and ICAM-1 production [89].

Another molecular pathway involved is the one of the protease-activated receptor and was demonstrated by the administration of activated C-protein upon liver $\mathrm{I} / \mathrm{R}$, and resulted in reduced several beneficial outcomes in the kidney: expression of several pro-inflammatory genes, reduced degradation of filamentous actin, lesser neutrophil infiltration and better preservation of vascular permeability [90]. Besides that, it has been proposed that the pre-treatment with platelet-activating factor (PAF) receptor antagonist also resulted in attenuation of renal injury after liver I/R [91].

Regarding the nervous system, it is widespread knowledge that the neuronal activity is particularly intertwined with the oxidative metabolism and is extremely sensitive to oxygen and glucose deprivation [92] and, therefore I/R insult to the brain calls for special attention. The pathophysiology of neuronal damage in ischemic stroke is complex, multifactorial and dynamic, and remarkably pivots around the axis of the neuroinflammatory cascade. In stroke patients, neural tissue ischemia triggers an acute systemic inflammatory reaction characterized by a significant increase in blood C-reactive protein (CRP) and Interleukin-6 (IL-6) [93]. Systemic inflammation amplifies a local inflammatory reaction in the brain due, at least partially, to the activation of the innate immune response of the central nervous system. These events result in microglia activation and a marked increase in proinflammatory cytokines, chemokines, mRNA and protein levels in the brain $[93,94]$. Chronic, lowgrade inflammation that is related to comorbidities such as hypertension, diabetes mellitus, obesity, atrial fibrillation, smoking, coronary artery disease, and heart failure is then superimposed to the acute, systemic inflammation, yielding a scenario of enhanced stroke risk [94]. During post-ischemia reperfusion, polymorphonuclear neutrophils exacerbate tissue damage especially via two different mechanisms: the physical obstruction of vessels and the release of oxygen radicals, proinflammatory cytokines, and cytolytic enzymes [95]. IRI also stimulates local microvascular responses, which include enhanced oxidative stress, activation of ischemic brain endothelial cells, platelet-leukocyte-endothelial cell interactions in the cerebral microvasculature, and an enhanced risk of thrombus formation in cerebral blood vessels. All of these mechanisms can lead to disruption of the blood-brain barrier with consequent hemorrhagic transformation [94]. The inflammatory response is considered by some authors as a double-edged sword, as it not only exacerbates secondary brain injury in the acute stage of stroke but also beneficially contributes to brain recovery after stroke owing to a dynamic balance between anti and pro-inflammatory mediators [94]. The mechanisms related to systemic inflammation and poor outcome include mainly: i) increased neutrophil infiltration of the cerebral cortex, ii) disruption of the blood-brain barrier, iii) impaired tissue reperfusion, iv) increased platelet activation, and v) microvascular coagulation and complement-dependent brain injury [93]. 


\section{Therapeutics: the Pharmacological Approach}

Despite different approaches, all the drugs used against the damaging process of ischemia and reperfusion aim for the agonism or antagonism of key events in the cell, i.e., those of protecting and harmful nature, respectively. Many pharmacological interventions reported in the literature involve the direct use of naturally occurring cell substances (i.e., glutathione [96] and melatonin [97]), while others employ mimetic (i.e., $N$-acetylcysteine [98]) or metabolism shifting drugs (i.e., trimetazidine [99-101]).

The IRI mechanism has been studied for decades and, there is yet no consensus regarding the details of the intrinsic biochemical pathways that are activated during the process. In this review, we present and classify the drugs according to the rationale of the currently accepted IRI signaling and final targets.

It is, however, widely agreed that the mechanisms of IRI are of a multifactorial nature $[5,24,102]$, involving complex signaling pathways which regulate a fine balance between anti and pro-apoptotic modulators [103], and their effects have been studied most frequently in myocardial tissue [104]. Therefore, within this context, the synergistic activation/inhibition of several protecting/deleterious pathways using combined agents represents an attractive strategy in this context. The modulation can occur intrinsically in the target cells, or extrinsically, by altering physiological parameters systemically, like those seen in angiogenesis, inflammatory response and metabolic status.

\subsection{Representative Pharmacological Targets}

Among a myriad of possible target sites, a significant amount is involved in a few, wellcharacterized pathways (Figure 2), namely the Reperfusion Injury Salvage Kinase (RISK) [102], the Survivor Activating Factor Enhancement (SAFE) [102], the cyclic guanosine 3',5'-monophosphate/ Protein Kinase G (cGMP/PKG), as well as a combination of others (inflammatory, metabolic, intrinsic/mitochondrial factors, nuclear DNA). In order to avoid redundancy, in this review we chose not to discuss some important pathways that already have been reviewed very recently, readers who are particularly interested in any of those, should refer to the provided bibliography: hypoxia-inducible factor (HIF) pathway and antioxidant transcription factor Nrf2 [105], AMPK pathway [106], additional autophagy, mitoptosis, necrosis and necroptosis, and apoptosis pathways [107]. It is also important to note that many of the pathways discussed here, although following different routes, frequently converge into critical events, of foremost importance among them the opening of mPTP. Here we list the grouping of pathways from the viewpoint of the "multi-target hypothesis", based on the structuration described in a recent review by Rossello and Yellon (2018) [102].

The RISK pathway, in a general sense is a pathway that is linked to a group of pro-survival (anti-apoptotic) protein kinases that are fundamentally linked to the IRI, consisting of a combination of two independent cascades that encompass either the phosphoinositide-3 kinase/protein kinase B (PI3K-Akt) or mitogen-activated extracellular signal-regulated kinase (MAPK, MEK1/ERK1/ERK2), both being triggered at the time of reperfusion and proven to exert cardioprotection [102]. The RISK pathway is engaged via two types of membrane receptors: either G-protein coupled receptors (GCPR) such as the receptors activated by adenosine $\left(\mathrm{A}_{1}, \mathrm{~A}_{3}, \mathrm{~A}_{2 \mathrm{~A}}\right.$, and $\left.\mathrm{A}_{2 \mathrm{~B}}\right)$, bradykinin $\left(\mathrm{B}_{1}\right)$ and opioids ( $\delta$ ) [108], or receptor tyrosine kinases (RTK), activated by cytokines, insulin, insulin-like growth factor-1 (IGF-1), erythropoietin and many others $[109,110]$. Even though RISK has two well-delineated routes, its final modulation always culminates in inhibition of the opening of the MPTP and the consequential pro-survival (anti-apoptosis) effect.

Although the signaling agents and their interaction involving the PI3K-Akt and MEK1/ERK1/2 have been scrutinized for quite a long time, it was only more recently that Yellon's group described them specifically from the IRI viewpoint $[109,111]$. The RISK routes have been dissected by a series of pharmacological studies based on numerous interventions by PI3K and ERK inhibitors at diverse levels [111], with many reports of their importance having been published since then [112-115]. 


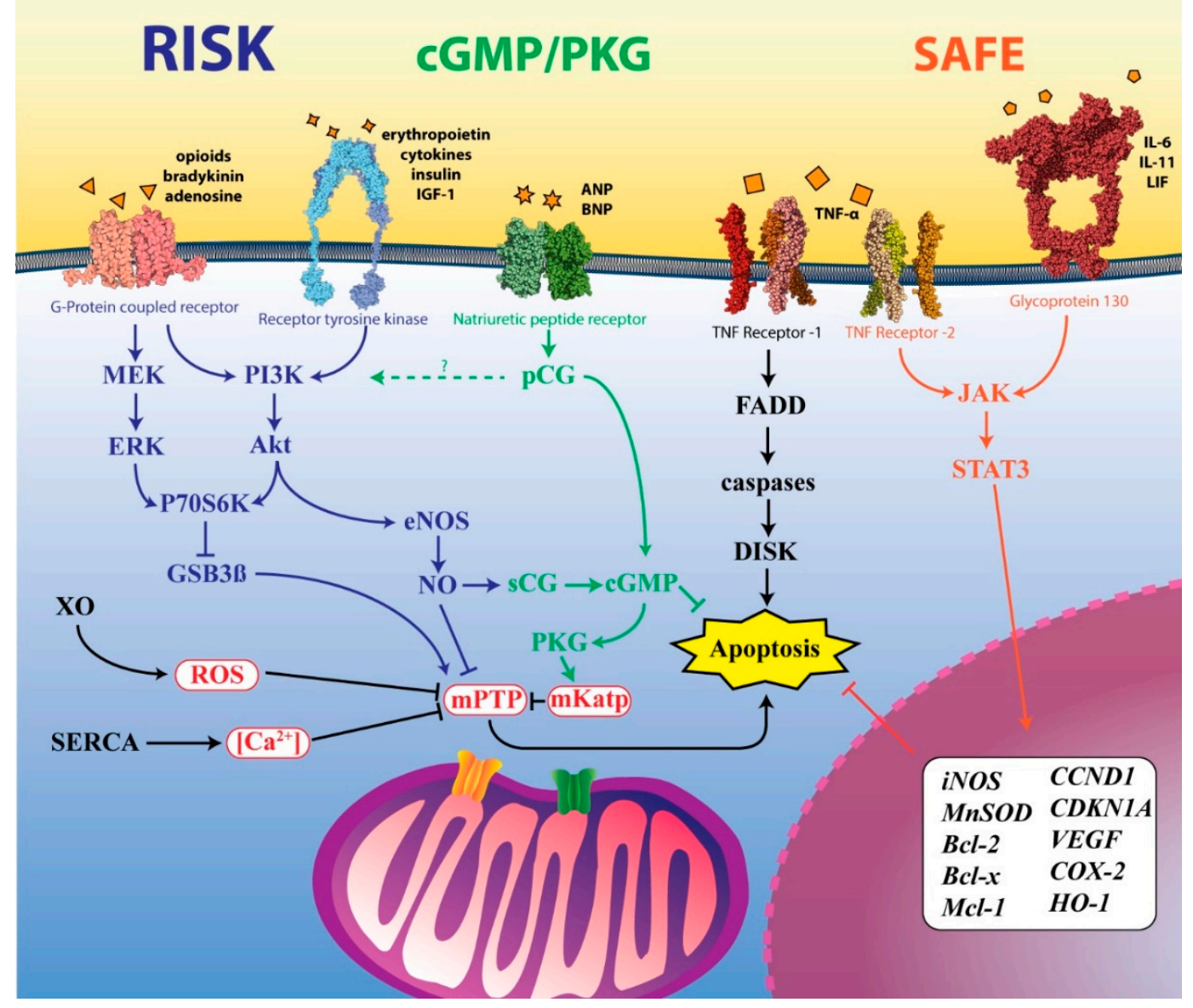

Figure 2. Simplified overview of the signaling pathways in the target cells presented in this review that are relevant for the development of a pharmacological therapy rationale. Systemic modulators were excluded from the figure. The RISK pathway (in green) is commonly activated via G-protein coupled receptors by opioids, bradykinin, and adenosine or the receptor tyrosine kinase, by erythropoietin, cytokines, insulin or insulin-like growth factor-1. The cGMP/PKG pathway (in green) receives external stimuli through the activation of the natriuretic peptide receptor, by natriuretic peptides A and B (ANP, $\mathrm{BNP}$ ). The SAFE pathway is engaged via the glycoprotein 130 receptor or TNF- $\alpha$ receptor type 2 by IL- 6 , IL-11, leukemia inhibitory factor (LIF) or TNF-a. A fourth pathway, the TNF- $\alpha$ receptor type- 1 is the only of deleterious character depicted in this figure. The xanthine-oxidase $(\mathrm{XO})$ and sarco/endoplasmic reticulum $\mathrm{Ca}^{2+}$-ATPase (SERCA) pathways are shown only in order to highlight their targets. Pointed arrows mean stimulation, blunt arrows mean inhibition.

Studies at the preclinical level have confirmed that at least partial activation of RISK upon reperfusion following ischemia does confer protection and therefore reduces the infarct intensity significantly [116]. It is also exciting to acknowledge that RISK has been shown to be involved in the protective non-pharmacological approach to ischemic pre- and postconditioning [116], an aspect which is particularly convenient for the investigation of key biochemical steps, aiming at the rational design and/or discovery of mimetic drugs.

The SAFE pathway was named in 2009 by Lecour [117] when describing the apparent paradoxical protective/deleterious effect that TNF-alpha seemed to have upon myocytes subjected to IRI. TNF-alpha can activate two types of membrane receptors, TNF- $\mathrm{R}_{1}$ (p55) or TNF- $\mathrm{R}_{2}$ (p75) [118], each of which signals to different cascades, culminating with either the Fas-associated death domain (FADD), caspase activation and apoptosis (type 1 receptor) or, among others, with the Janus kinase/signal transducer and activator of transcription 3 (JAK/STAT-3), engaging the SAFE pathway and therefore leading to cell survival (type 2 receptor) [108]. The SAFE pathway can also be engaged by activation 
of the glycoprotein 130 receptor via inflammatory cytokines (IL-6, IL-11, and leukemia inhibitory factor-LIF) [119]. From that point, the JAK/STAT-3 route is placed under the SAFE pathway, which, when stimulated culminates in inhibition of the MPTP opening and the nuclear transcription enhancement of cell survival and proliferation genes, such as Bcl-2 [120], Bcl-x(L) [120], Mcl-1 [120,121], CCND1 (cyclin D1) [122], CDKN1A (p21) [123], some growth factors (VEGF) [124] and other transcription factors $[117,125,126]$. The SAFE pathway can upregulate STAT-3 and significantly lessen the myocardial injury at the time of reperfusion [117], being independently activated in relation to RISK, and therefore opening possibilities for synergistic approaches.

The cGMP/PKG pathway modulates the production of the second messenger cGMP by guanylyl cyclases and the activation of distal cGMP or cAMP-dependent protein kinase activation (PKG and PKA, respectively). The PKs are, in turn, effectors of pro-survival actions, such as the opening of mitochondrial ATP-sensitive $\mathrm{K}^{+}$channels $\left(\mathrm{mK}_{\text {ATP }}\right.$ ) [127] as well as the maintenance of sarcoplasmic reticulum $\mathrm{Ca}^{2+}$ homeostasis [104]. The GCs are divided into two categories. The first consists of the particulate guanylyl cyclases (pCG), which are integral membrane proteins that can be activated by extracellular (atrial and brain) natriuretic peptides (NPs) via the conjugated natriuretic membrane receptors [104]. Several G-coupled receptors are activated by both ischemic pre- and postconditioning, and they are likely to be activated independently of each other [128]. The other category is one of the soluble guanylyl cyclases (sCG), which are dispersed in the cytoplasm and are activated by nitrites (mainly $\mathrm{NO}$ ) that, in turn, can be either originated systemically or produced intracellularly by eNOS [129]. Preconditioning or postconditioning with exogenous cGMP/PKG modulators, such as donated NO, natriuretic factors and phosphodiesterase inhibitors, as well as endogenous NO stimulating drugs, have been proven successful to be liver/cardioprotective by activation of both cytosolic and mitochondrial mechanisms [130-132]. For an updated and thorough review more specifically about the cGMP/PKG pathway, please refer to Inserte and Garcia-Dorado [133].

Several protective drugs modulate other independent routes that may alternatively be activated during reperfusion and that are not assigned to the RISK, SAFE or the cGMP/PKC pathways. They can have different types of effects such as such as inhibition of ROS-producing complexes [18,67,134-143], or may act as anti-apoptotic [144], anti-inflammatory [24,53,145-164] and antioxidants agents [165-194], as glucose metabolism enhancers [99-101,150,195-205], adenosine receptor modulators [206-219], matrix metalloproteinases (MMP) inhibitors [153,220-226], direct mPTP inhibitors [227-242], $\mathrm{K}_{\text {ATP }}$ or $\mathrm{mK}_{\text {ATP }}$ agonists [243-248], and respiratory chain direct modulators [30-32,249-264].

Finally, when one takes into account that the concept of the biochemical pathway is an artificial construct and the cell is completely oblivious to it, it can be understood that a single drug commonly interferes with more than one-step of distinct pathways. In fact, many membrane receptors display a somewhat promiscuous behavior of homo and heterodimerization with different receptor subtypes or receptor classes [265]. Therefore, it is important to keep in mind that many drugs may (and do) act upon more than one pathway.

\subsection{Pharmacological Targeting of the RISK Pathway}

Although many drugs may interact with the RISK pathway, it is urocortin that was the first to be associated with it [111]. Urocortin was originally cloned from rat tissue and subsequently from the human brain. It is a stress-related mammalian mediator consisting of a structure of a 40-aminoacid alpha-helix and is related to the hypothalamic hormone corticotrophin-releasing factor [266]. Schulman et al. demonstrated that urocortin binds its heart receptors (GPCR) and increases the phosphorylation of ERK1 and ERK2 (also known as p44 and p42, respectively), and therefore protecting the organ from lethal reperfusion injury [111]. Confirming these results, the authors observed that the beneficial effects of urocortin were nullified when an ERK 1/2 inhibitor, PD98059, was co-administered. Similar results were obtained by Baxter et al. [267] when they observed that the protective effects of transforming growth factor- $\beta 1$ (TGF- $\beta 1$ ) were eliminated by the same inhibitor. 
Polyethylene glycols (PEG) have been shown to exert protective effects in myocytes submitted to post-hypoxia reperfusion by several properties [268,269]. Apart from being routinely used as oncotic agents, in preservation solutions, rinse solutions, preconditioning and supercooling, PEGs can lessen IRI by promoting the protection of the mitochondria and cytoskeleton. Also, Bejaoui et al. provided evidence that PEGs stimulate pro-survival pathway via phosphorylation of AKT, as well as activation of two important cytoprotective factors, e-NOS and AMPK [270]. More recently, intravenously administered PEGs of various molecular weights have been successfully used as preconditioning agents, greatly enhancing the transplantation viability of liver grafts [269]. This outcome may be attributed to both the physical and chemical properties of PEGs, such as a relatively high molecular weight, low toxicity, high flexibility, hydrophilicity, increased hydrodynamic volume and high protein-rejecting properties [271]. Additionally, Lopez et al. demonstrated that the presence of a high weight PEG (PEG35) in preservation solutions during cold ischemia time could provide even further protection against hypoxia by improving the structural integrity of the endothelial glycocalyx and therefore maintaining its ability to mediate NO synthesis [272]. These results may pave the way for extending cold storage time, allowing the expansion of the organ donor pool by the inclusion of marginal grafts that would otherwise be unviable [272].

Undoubtedly, the list of drugs and factors that activate at least partially RISK pathway and elicit cardioprotection is enormous and ever-increasing. Their effect may occur during pre or post-ischemic stages and may or may not be mediated by receptors. Some prominent agents that bind to the RTK receptor are insulin, IGF-1, FGF-2, erythropoietin, leptin, visfatin, apelin and cytokines in general. In turn, some substances that show IRI protection and bind to the GPCR receptor are urocortin, adenosine, bradykinin, opioids, adrenomedullin and glucagon-like peptide 1 (GLP-1). To describe all of them is beyond the scope of this review, so for the reader who has a special interest in this specific matter, we suggest as a good a starting point the work of Hausenloy and Yellon [116].

\subsection{Pharmacological Targeting of the SAFE Pathway}

For a long time, the well-known cytokine tumor necrosis factor-alpha (TNF- $\alpha$ ) was held accountable for myocardial dysfunction in events where hypoxia was established for enough time, notably in IRI or heart failure [117]. Nowadays, however, there is widespread evidence that TNF- $\alpha$ may be found both in damaged and healthy tissue. Nevertheless, attempts to both neutralize and stimulate TNF- $\alpha$ in post-myocardial infarction patients during ischemia and reperfusion have resulted in worsening the condition of the heart [117]. This seeming paradox begins to be clarified by the duality of membrane receptors that TNF- $\alpha$ may stimulate depending on various factors, one of them being its concentration [118]: TNF- $\mathrm{R}_{1}$ (p55) activates an apoptotic response and is more sensitive to a lower dosage (usually physiological values), and TNF- $\mathrm{R}_{2}$ (p75) usually requires an (endogenously) higher concentration and signals to the SAFE pathway, promoting cell survival $[117,273,274]$. Also, while TNF- $\mathrm{R}_{1}$ is likely expressed in every cell, TNF- $\mathrm{R}_{2}$ is further expressed among immune system cells and in the endothelium $[275,276]$. By experimenting with anti-TNF antibodies and knockout mice, Flaherty at al [277] observed that standalone TNF- $R_{2}$ is responsible for reducing infarct size following IRI, whereas standalone TNF- $\mathrm{R}_{1}$ had no such effect. Also, they demonstrated that the beneficial effects of ischemic preconditioning are established only when there is no redundancy in the signal triggered by both types of receptors.

These advances have provided yet another solid basis for the development of new anti-ischemic strategies. Shibata et al. showed that TNF- $\alpha$ is responsible for the down-regulation adiponectin, of an essential metabolic cytokine [278]. This cytokine is specifically produced by fatty tissue, therefore being known as an adipokine, and its presence is associated with increased protection against ischemia, by enhancing energy expenditure in association with the upregulation of mitochondrial uncoupling proteins [279]. By employing etanercept as a TNF- $\alpha$ antagonist before reperfusion, Gao et al. achieved cardioprotective effects in mice subjected to 30-min of myocardial ischemia. This effect may be partially attributed to the upregulation of adiponectin expression, which may lead to cardioprotection by AMPK 
activation [280] and stimulation of prostaglandin $\mathrm{E}_{2}\left(\mathrm{PGE}_{2}\right)$ release from myocytes, fibroblasts and of cyclooxygenase-2 (COX-2) release, inhibiting the production of TNF- $\alpha$ in monocytic cells [278].

Some impressive results have also been achieved with another anti-TNF- $\alpha$ agent, the humanized mouse monoclonal antibody infliximab. Being routinely used for the treatment of several autoimmune diseases such as rheumatoid arthritis, Crohn's disease, and psoriasis, infliximab was also shown to be a promising alternative against IRI by Tasdemir et al. [24]. Using this drug, the authors were able to reduce rat kidney lipid peroxidation by increasing glutathione levels and SOD activity, even observing the restoration of histopathological alterations [281]. Also, Nagata et al. found that pre-ischemic treatment with infliximab had the same protective effect as preventive splenectomy in rat kidney transplantation $[282,283]$, reducing renal macrophages and monocyte infiltration and the consequential release of inflammatory cytokines. This is a typical example of the potential of pharmacological approaches as a much less invasive alternative. Some anesthetics such as propofol as well as the gaseous agents, isoflurane and sevoflurane, also act upon the SAFE pathway and protect against IRI. All three of them reduce oxidative stress and therefore seem to act by pleiotropy as anti-apoptotic agents. Isoflurane is also known to modulate mitochondrial bioenergetics in the myocardium by selective and partial inhibition of respiratory complexes I and III (discussed later) [284]. Jeong et al. [144] reported that the protective effects of ischemic preconditioning on the liver are enhanced with concomitant use of isoflurane or sevoflurane. The authors, however, found no significant IRI protection by the sole use of either substance without the step of preconditioning, providing evidence of a desirable synergism among distinct processes. These results were achieved at least in part by the 2.3-fold and 1.7-fold upregulation of the expression of the anti-apoptotic gene Bcl-2 by in the isoflurane/IP and sevoflurane/IP groups, respectively. Yang et al. [149] had already demonstrated that another ubiquitous anesthetic, propofol (2,6-diisopropylphenol) also had an anti-inflammatory effect in the rat kidney by upregulating bone morphogenetic protein 2 (BMP-2). Later, Xu et al. [148] expanded the understanding that both sevoflurane and propofol, can reduce oxidative stress in the liver, as well as alter the anti and pro-apoptotic gene expression and therefore inhibit apoptosis. They found that the anti-inflammatory effects of propofol and sevoflurane can also be attributed to the inhibition of the transcriptional factor NFkB (nuclear factor kappa B), which reduces the expression of pro-inflammatory cytokines (IL-6, IL-1, and TNF- $\alpha$ ) while increasing the expression of the anti-inflammatory IL-10 expression in the rat liver. Overall, the oxidative stress was attenuated by increased expression of SOD and anti-apoptotic proteins Bcl-2 and Bcl-xl, with a reduction of MDA levels and of the apoptotic proteins Bax and Bak. Particularly, while both substances provided similar protection, propofol-induced lower IL-1 release, whereas sevoflurane sharply decreased TNF-a leakage.

Katayama et al. [152] reported that another example of the SAFE pathway stimulation and increased expression of nuclear anti-apoptotic expression by preconditioning the rat brain with erythromycin. This well-known antibiotic can improve neuronal survival upon IRI by reducing the infarct size and edema volume, representing a promising neuroprotective agent for acute ischemic stroke [152]. The proposed mechanism is that of antioxidant and anti-inflammatory activity, with a transient increase of expression of Bcl-2. The protective effects of erythromycin were also confirmed in a porcine model, with the administration of a single dose $12 \mathrm{~h}$ before the induced acute hypothermic circulatory arrest, reducing the intensity of apoptosis in the neocortex after the ischemic period [53]. Along with these findings, the long history of use and safety of erythromycin recommends this agent as a potential candidate for the development of safer surgical protocols.

For didactic purposes, chemicals that act mainly as antioxidants by regulating the general redox state and providing alleviation of oxidative stress rather than by direct enzyme regulation will be discussed under the antioxidant category.

\subsection{Pharmacological Targeting of the cGMP/PKG Pathway}

The general cGMP/PKG pathway comprises many steps and branches that are still rather obscure in the context of protection against IRI. Many authors nowadays simplify this complex pathway by 
comprises some of it in the RISK pathway, as previously stated. However, there are a few steps that are still disputed and pose a matter of divergence. Since the cGMP/PKG is the pathway of the guanylyl cyclases (GC), here we consider these enzymes as the starting point for signal transduction up to the direct activation of the primary mediator PKG and, indirectly, the activation of PKA via phosphodiesterases [285].

Bolus or continuous infusion of the phosphodiesterase-5 (PDE-5) inhibitors sildenafil or vardenafil at concentrations lower than those for the treatment of erectile dysfunction has a cardioprotective effect at reperfusion through the opening of mitochondrial $\mathrm{K}_{\text {ATP }}$ channels in the heart, reducing infarct size in vivo in rabbits [286] and rats [287]. Interestingly, another PDE-5 inhibitors, tadalafil [288] and ordonafil [289], show similar cardioprotection against IRI in rabbits and rats, thus strengthening the idea that such protection may be considered to be a generalized class effect [289]. The PDE-5 inhibition leads to downstream accumulation of cGMP [286], engaging the anti-apoptotic effect from the opening of the $\mathrm{mK}_{\mathrm{ATP}}$. A very similar mechanism and results were also achieved with the use of the soluble GC activator BAY 60-2770 [290].

For more than two decades now, exogenous adenosine has been known to intensify the protective effects of ischemic preconditioning by, among others, increasing of Akt/eNOs engagement [291]. However, the knowledge of the pharmacodynamics of IRI protection by adenosine has greatly expanded, allowing further expansion of its uses. The properties of adenosine range from cell signaling, vasodilation, action as a norepinephrine-antagonist, pro- or anti-inflammatory and negative inotropic and chronotropic effects, some of which were demonstrated to provide superior protection in adenosine-rich cardioplegic solutions over hyperkalemic solutions [206,292]. The vast range of properties of adenosine during IR are mostly related to its four distinct concentration-dependent receptors $\left(A_{1}, A_{2 A}, A_{2 B}\right.$, and $\left.A_{3}\right)$ and their uneven distribution in the body. While all of them modulate adenylate cyclases activities, A1 and A3 are G-inhibitory $\left(\mathrm{G}_{\mathrm{i}}\right)$, and A2A and A2B are G-stimulating $\left(G_{s}\right)$ [206]. Physiological concentrations of adenosine $(<1 \mu \mathrm{M})$ can activate in the organs all but one receptor, $\mathrm{A}_{2 \mathrm{~B}}$, which will, in turn, be activated mostly during pathological conditions such as hypoxia [293]. The lower concentrations of adenosine can cause $A_{1}$ receptors to inhibit the activation of adenylate cyclase by the $\mathrm{A}_{2 \mathrm{~A}}$ cascade, but, at higher concentrations, $\mathrm{A} 1$ receptors are overwhelmed by the $A_{2 A}$ and $A_{2 B}$ [294]. Likewise, in pathological conditions, most immune cells (neutrophils, lymphocytes, and platelets [223]) may sequentially express all types of receptors with increasing adenosine concentrations [295].

Pharmacological limitations and an intricate web of pathways make the literature on the role of adenosine receptors in IRI somewhat controversial, especially about $A_{2 B}$, which seems to be of a protective or deleterious nature under distinct pathophysiologic settings, thus making the development of agonist or antagonists a challenging choice [207]. Boros et al. showed that adenosine attenuates myocardial damage from IRI by decreasing immune cell infiltration via cytokine [206]. Recently, Paez et al. explained that the reduction of myocardial infarct size they achieved in the rat by remote ischemic preconditioning was mostly due to the activation of $\mathrm{A}_{1}$ receptors in the mitochondria early during reperfusion, and the consequent engagement of RISK and Akt/eNOS phosphorylation [208]. Cao and colleagues used the $\mathrm{A}_{2 \mathrm{~A}}$ agonist CGS-21680 and the antagonist ZM-241385 to evaluate the apoptosis index in dermal microvascular endothelial cells (DMECs) that were submitted to ischemic postconditioning [210]. They found that IRI to DMECs was significantly attenuated by ischemic postconditioning or agonism of $\mathrm{A}_{2 \mathrm{~A}}$ receptors and, inversely worsened by its antagonism. In agreement, agonism of $\mathrm{A}_{2 \mathrm{~A}}$ receptors can also attenuate IRI in a porcine model of extracorporeal cardiopulmonary resuscitation by lowering the lactate peak after reperfusion, as well as the markers of inflammation and liver and kidney stress [211]. Selective antagonism of $\mathrm{A}_{2 \mathrm{~A}}$ has been, however, frequently shown to achieve protective outcomes [212-214]. More recently, Mohamed and colleagues, have been showing that with central $\mathrm{A}_{2 \mathrm{~A}}$ antagonism, it is possible to reduce the inflammatory signals and therefore suppress apoptotic pathways in the rat brain $[215,216]$. Huerter et al. confirmed such anti-inflammatory and protective properties in the murine lung submitted to IRI [217]. These findings support the idea 
that both $\mathrm{A}_{2 \mathrm{~A}}$ and $\mathrm{A}_{2 \mathrm{~B}}$ are activated in situ by hypoxia and contribute to the preservation of myocardial tissue [209].

The current literature shows that $\mathrm{A}_{3}$ agonism provides ischemic tolerance and is both effective and safe [207]. By using the A3 agonist CP-532,903, Wan et al. achieved protection of mouse myocardium from IRI, results that were abolished by using knockout mice that lack A3 only in the cardiomyocytes [218]. They claim that the protective mechanism is coupled to the activation of $K_{\text {ATP }}$ channels via inhibitory G-proteins. The use of another highly selective $\mathrm{A}_{3}$ agonist, CF102, revealed that this pharmacological strategy can also protect the liver via the downregulation of the NF- $\kappa B$ signaling pathway [219].

$\mathrm{NO} / \mathrm{cGMP}$ inhibition would make a difference in the treatments of vasoplegia and IRI. Our 25 years of experimental and clinical experience have led us to believe that methylene blue (MB) is a compound that can be effectively employed $[18,49,296-301]$. The effects of MB are apparent only regarding NO up-regulation, while the compound, per se, cannot be considered to act as a vasoconstrictor. It is by the "releasing" of the cAMP system and the blocking of the cGMP system that ultimately, the vasoconstrictor effect of noradrenaline is triggered $[136,298]$. We recently wrote an editorial opinion suggesting this hypothesis as a new therapeutic target for the pharmaceutical industry. MB is not patented for industrial or medical use. Even considering its safety at low doses, but the medical literature insists that it has not been submitted to any trial. However, it is mandatory to emphasize its new use and not its use as rescue therapy [47].

Intravital investigations have shown a possible MB protection of the microcirculation. In an experimental study of septic shock in rats, only the combination of norepinephrine (NE) and $\mathrm{MB}$ combination restored mean arterial pressure to control after $3 \mathrm{~h}$ of observation. Better microvascular integrity was observed in the presence of $\mathrm{MB}$, as opposed to severe damage to animals that were infused with only NE [302]. Therefore, MB would be an option for the prevention of direct organ damage by adrenergic agents, although it still remains an unexplored frontier by the pharmaceutical industry [47]. Levy and colleagues wrote an excellent review article about the "past, present and future" of vasoplegia treatment and expressed some concerns about the use of MB [303]. Without considering MB itself, the blockade of soluble sGC, the final NO/cGMP messenger, in smooth muscle is underestimated and deserves a place in the present and future [303,304].

\subsection{Pharmacological Targeting of the Mitochondria}

It is well known that IRI follows the philosophy of "almost all routes lead to the MPTP opening" and, so far in this review, we have seen drugs that indirectly modulate that event. In this paragraph, we present, however, examples of drugs that overlook all these pathways and go to the point: the direct mPTP inhibitors.

Since the 1990s, most studies about IRI protection that focus on avoiding the MPTP opening have been conducted by inhibition of cyclophilin $\mathrm{D}(\mathrm{CyD})$, an essential and the most characterized modulator of the MPTP, which makes it a key target for circumventing necrotic cell death [305]. CyD was so named because of its high affinity for cyclosporine A (CyA), an immunosuppressant drug that has then become the prototype of $\mathrm{CyD}$ inhibitors. Many literature reports of successful experimental IRI attenuation in the liver by CyA treatment [227,306], heart [228,307], and brain [233,305] are available. Nevertheless, over the last decades, there has been a consistent decline of these reports, a reflection of negative outcomes from recent large clinical studies, where CyA failed to demonstrate its efficacy in myocardial infarction [230,232,308]. Also, it is now generally regarded that the use of CyA in the long-term management of IR-based diseases or immunosuppression in transplantation, is no longer clinically plausible, for its risks outweigh its benefits [231,309-311]. In the face of such a scenario, the scientific community has been questioning whether $\mathrm{CyD}$ can be indeed a viable target [34].

Therefore, novel strategies are being developed either to fine-tune the therapeutics with CyA or to switch altogether to the assessment of CyA analogs. Ikeda et al. have developed a poly-lactic/glycolic acid nanoparticle-mediated delivery system of CyA that ensures a higher drug concentration directly to the mitochondria during reperfusion, inducing cardioprotection in vivo in a murine 
IR model [229]. On the other hand, the CyA analogs alisporivir/debio-025 [238], sanglifehrin A [234,312] and (NIM811) [240,313] are also showing progress against IRI in the myocardium, liver, and brain in animal models. Although not a CyA analog, it has been recently shown that the classic vasodilator nitroglycerine (glyceryl trinitrate) also inhibits CyD via $S$-nitrosation, and therefore limits I/R-driven myocardial infarction in rabbits [314].

Yet, in the last ten years, much attention has been directed to the identification of novel compounds that can inhibit mPTP opening without any modulation of the $\mathrm{CyD}$, a clever strategy that can open exciting, innovative therapeutic possibilities, with a more intense effect being achieved with the addition of CyA-based treatments. So far, compounds such as $\mathrm{N}$-phenylbenzamides [315], cinnamic anilides [316-318], isoxazoles [319], TRO40303 [320] have already been proven to thoroughly inhibit mPTP, with many of them even showing different nuances of protection in animal disease models. Most of these compounds must yet undergo proof-of-concept trials and have their safety and clinical effectiveness to be scrutinized. The once-promising compound TRO40303, however, has performed poorly in more than one translational study [321,322], with its clinical relevance regarding the reduction of IRI due to percutaneous coronary intervention for acute myocardial infarction. It is worth mentioning that hydroxytyrosol, a phenolic compound found in olive oil, provided significant protection to the myocardium against IRI, by inhibiting MPTP opening although it is still unclear whether or not this effect is CyD-dependent [323].

The opening of mitochondrial ATP sensitive potassium channels $\left(\mathrm{mK}_{\mathrm{ATP}}\right)$ during IR is a desirable protective measure, for it shifts the threshold of MPTP activation, delaying the engaging of the apoptosis pathway. Also, non-mitochondrial $\mathrm{K}_{\mathrm{ATP}}$ can also exert another form of protection from IRI by stimulating blood flow and therefore, pre-ischemia nutrient surplus. Shimizy et al. were able to achieve protection from IRI at the level of the proximal tubules in the rat kidney with nicorandil (selective $\mathrm{mK}_{\text {ATP }}$ agonist and $\mathrm{NO}$ donor) and cromakalim (a non-selective $\mathrm{K}_{\mathrm{ATP}}$ agonist, a vasodilator) [243]. Both nicorandil and cromakalim were also effective against cerebral IRI in diabetic rats, lowering caspase-3 levels, with the first also significantly reducing cerebral infarct volume [244]. Also, a drug clinically used to treat hypoglycemia, diazoxide, has been yielding promising results regarding ischemic tolerance and IRI protection in the heart, pancreas, smooth muscle, endothelium [245], intestine, liver [248], and spinal cord [246]. Although this agent acts through its classical mechanism as a selective $\mathrm{mK}_{\mathrm{ATP}}$ agonist, pretreatment with diazoxide may also engage the RISK and SAFE pathways by upregulating both the expression of the beta common receptor subunit of the erythropoietin receptor [247] and the STAT3 mechanism, respectively [246]. Literature reports in the literature show significant pharmacologic overlap between respiratory complex II inhibitors and $\mathrm{mK}_{\mathrm{ATP}}$ channel agonists: malonate [324] and atpenin A5 [325] are able to activate the $\mathrm{mK}_{\mathrm{ATP}}$ channel and offer cardioprotection in rats at reperfusion. This intimate interplay between $\mathrm{mK}_{\mathrm{ATP}}$ and the respiratory chain components has been well documented in the recent literature. For instance, it has been demonstrated that the uncoupling of complexes II and III promotes the opening of the $\mathrm{mK}_{\text {ATP }}$ channel, a mechanism that attenuates hyperoxygenation and ROS production upon reperfusion in the rat myocardium [326]. All of these mechanisms respond one way or another to acute oxidative stress, particularly through acute ROS production [327], and few cellular processes stand out as much as the mitochondrial electron transport chain, especially under the condition of reverse electron transport that takes place during reperfusion [31,32] and the consequent succinate accumulation (the so-called state of "oxidant-induced reduction") [30]. Therefore, direct modulators of the respiratory chain could be used to blockade RET during reperfusion, modulating excessive ROS production and therefore mPTP activation and cell death. It has been stated that different sites of anomalous ROS production in respiration complexes in the mitochondria contribute to specific pathologies, and current evidence points to complexes I, II and III as large contributors to amplification of IRI [328]. For an updated and in-depth review of the relations of respiratory complexes and ROS increase under the regimen of RET, please refer to the review by Chouchani et al. [29]. 
At this point, it is crucial to completely dismiss the outdated assumption that the role of cellular ROS is mostly of a deleterious character, generated solely as a metabolic byproduct and contributing to cellular damage. Although it is true that the excess of ROS does impose oxidative stress and possible MPTP opening, at lower concentrations, they act as important secondary messengers in many pathways, including protective and reparative ones [329]. Scialo et al. have shown that ROS signaling is site-specific and demonstrates that, while senescence-driven ROS production can be detrimental to Drosophila sp., ROS production derived from $\mathrm{QoQ}_{\mathrm{H} 2}$ oxidation (probably via RET) signals positively to complex I function and extends the lifespan of the insects [329]. Similarly, inhibition of complex I with metformin yields a small increase of ROS concentration above the physiological threshold and result in an extended lifespan in C. elegans [330,331]. Even though these specific mechanisms are not yet proven to be conserved in Mammalia, the principle of specificity of ROS-signaling is nonetheless a major breakthrough and should be incorporated into the rationale of future studies on IRI. We understand that an especially interesting starting point would be to determine whether there is a breakpoint (and which is it) where the ubiquinone:ubiquinol ratio $\left(\mathrm{CoQ} / \mathrm{QoQ}_{\mathrm{H} 2}\right)$ shifts a given steady cellular ROS concentration from deleterious to a protective character.

Among all four complexes, the respiratory complex I (NADH dehydrogenase), along with complex III, are the leading sites of superoxide production [32,332]. The condition of RET causes electrons from $\mathrm{QoQ}_{\mathrm{H} 2}$ to be transferred all the way through the respiratory chain back to complex I, where the ratio of $\mathrm{NAD}^{+} / \mathrm{NADH}$ is inverted, and intense ROS production develops [333]. However, regarding complex I modulation, the tried-and-true approach of simple enzyme agonism/antagonism is just too reductionist and far from adequate. This is due in part to the fact that the electron transfer throughout this complex occurs in two steps coordinated by two different conformations, and each of which is sensitive to different classes of inhibitors that can either induce or inhibit ROS generation [334]. Currently, these inhibitors are generally grouped into two classes, according to the conformation of the CoQ site $\left(\mathrm{I}_{\mathrm{Q}}\right)$ : the ROS-inducing class $\mathrm{A}$ is an antagonist of the CoQ substrate and, the ROS-preventing class $\mathrm{B}$ is an antagonist of the $\mathrm{QoQ}_{\mathrm{H} 2}$ product [334]. It is worth noting, however, that the ROS-generation is heavily modulated not only by the class of the inhibitor but also by the site it occupies, available substrates and their concentrations and whether the condition is ischemia or reperfusion [334-336].

Under physiological conditions, respiration is driven by NADH-linked substrate and the production of ROS by complex I is only basal, with a rate of roughly less than $100 \mathrm{H}_{2} \mathrm{O}_{2} / \mathrm{min} / \mathrm{mg}$ of protein in the rat skeletal muscle. In this scenario, a class A inhibitor causes a significant increase in ROS production, up to $2650 \pm \mathrm{H}_{2} \mathrm{O}_{2} / \mathrm{min} / \mathrm{mg}$ of protein. At post-ischemic reperfusion, however, RET causes and even higher ROS production, and here a class $\mathrm{A}$ inhibitor, like rotenone, will paradoxically decrease this rate by almost as 9-fold $\left(300 \pm 100 \mathrm{H}_{2} \mathrm{O}_{2} / \mathrm{min} / \mathrm{mg}\right.$ of protein) [337,338]. Hirst et al. point out that these observations are in agreement with the fact that during RET, an inhibited complex I prevents electron flow "upstream" to the ROS production site (FMN) $[339,340]$. Interestingly, this mechanism has also been identified in the rat brain, heart, liver and the human cortex [339]. In the context of $\mathrm{I} / \mathrm{R}$, rotenone has been used to demonstrate the concept that RET is established during reperfusion and its blockade can significantly attenuate IRI in the myocardium [249], kidney [252], intestine [341], and liver [187] of the rat.

However, the use of rotenone as a therapeutic agent is controversial since it has long been employed as a broad-spectrum insecticide, piscicide, and pesticide. Nevertheless, it has also recently been claimed to be safe and protective in low concentrations [252,330,342]. Therefore, many groups are studying reversible inhibitors, exploiting the advantage of a transiently inactivate complex I without the harm of permanent loss of activity. In this category, some compounds show good results in attenuating IRI in the rat/mouse myocardium: amobarbital (amytal) [250,343], S-nitroso-2-mercaptopropionyl glycine [344], MitoSNO [345] and OP2113 (anetholtrithion) [336]. Also, already cited in this review, metformin has been proven recently to be cardioprotective also as a modulator of complex-I. This effect, though, is only achieved when the drug is used as an acute, high-dose $(2 \mathrm{mM})$ at reperfusion, contrasting with its usual chronic posology [346]. 
Gadicherla reported that the antianginal drug ranolazine reduces complex I damage during cardiac I/R, attenuating tissue damage. Interestingly, they found that ranolazine does not have any direct interaction with complex I, and its protection is an effect derived from a reduction in the $\mathrm{Na}^{+} / \mathrm{Ca}^{2+}$ exchange in the cytosol, leading ultimately to the alleviation of a damaging mitochondrial $\left[\mathrm{Ca}^{2+}\right]$ overload [347]. A multidisciplinary effort by Orr [328], Brand [348] and colleagues has identified classes of small molecules that are able to selectively bind to the $\mathrm{I}_{\mathrm{Q}}$ site in the complex I (S1QELs) or to the Qo site in the complex III (S3QELs), preventing electron leakage and suppressing ROS production during RET without affecting oxidative phosphorylation, thus achieving attenuation of the IRI in the mouse heart.

As discussed, although the respiratory complex II (succinate dehydrogenase) is not per se a site of ROS production during reperfusion, it does modulate the activity of complexes I and III activities through succinate accumulation [30,332]. Mild inhibition of complex-II probably reduces the inner mitochondrial membrane potential and the supply of electrons, minimizing ROS production due to RET [349]. Dröse et al. demonstrated that complex-II inhibition by atpenin A5, diazoxide, malonate or 2-thenoyltrifluoroacetone (TTFA) at reperfusion mitigates/stimulates ROS generation by RET in complexes I and III [349]. With this method, they achieved cardioprotection independently of the presence of $\mathrm{K}^{+}$, confirming the standalone influence of complex-II in these experimental settings.

The acid citric intermediates malate and oxaloacetate, as well as the succinate-competitor malonate, are long known complex II inhibitors $[350,351]$ and, not surprisingly, have been ubiquitously studied as IRI evaders. Malonate treatment of isolated mouse hearts before ischemia [30] or at the onset of reperfusion [352] show a significant reduction in infarct size by reducing ROS production and avoiding MPTP opening. Promising results have also been seen in a swine model of transient coronary occlusion [353]. Intracoronary malonate at early reperfusion prevents excessive ROS build-up and limits infarct size. The authors reported that this treatment correspondingly improves systolic shortening in the area at risk, without, however, modifying reperfusion arrhythmias. Likewise, mouse myocardium under ischemia treated with a more membrane-permeable form of the complex II inhibitor malonate, dimethyl malonate, also showed lesser ischemic succinate accumulation and subsequent abolition of local ROS production $[30,32,253]$. However, malonate administration has been reported to exert systemic toxicity, so that its therapeutic use requires prudence [353].

Oxaloacetate attenuates damage from warm $\mathrm{I} / \mathrm{R}$ in the rat liver by improving hepatocytes bioenergetics, though without evident involvement of complex II modulation [354]. It has also been successfully employed as a blood glutamate scavenger to prevent post-ischemic long-term potentiation impairment in the rat hippocampus [355].

Guo et al. [356], demonstrated that the anticancer agent lonidamine can selectively inhibit the succinate-ubiquinone reductase activity of respiratory complex II without efficiently blocking its succinate dehydrogenase activity causing downregulation of fumarate and malate and leading to succinate accumulation without the onset of hypoxia. Although in this particular study the authors did not use lonidamine to investigate IRI protection specifically, it is undeniable that its properties of succinate accumulation of this agent can be of interest in terms of the induction of chemical ischemia-like state in future studies.

In the context of IRI, fatty acid nitroalkenes (particularly nitro-linoleate and nitro-oleate) stand out as yet another promising approach investigated in the last years. Although certainly much more will be unveiled in the next years, we already know some of the fascinating properties shared by these compounds share as a group. They have been shown to behave as anti-inflammatory agents [357], modulators of mitochondrial redox and metabolic shifts by reversibly inhibition of mitochondrial respiration at complex II [358], and regulators of the Nrf2 and NF- $\mathrm{kB}$ signaling in rodents [359] and adenine nucleotide translocator (ANT1)-mediated mitochondrial uncoupling [360]. The potential of nitroalkenes as an effective therapeutic alternative for myocardial IRI seems to be gaining momentum. It has been recently demonstrated that nitro-oleic acid promotes substandard ROS output during an ischemic period in isolated rat heart mitochondria as a function of the $\mathrm{pH}$ [358], and can induce 
notable protection of the myocardium in a murine model, reducing the infarcted area by as much as $46 \%$ [357]. A conspicuous feature of most therapeutically relevant nitroalkenes is that they show high bioavailability and can be administered endogenously [357] or de novo generated via gastric formation in rodents, by supplementation with conjugated linoleic acid and $\mathrm{NO}_{2}$ [359]. Nitro-linoleate/oleate directly modifies the redox-sensitive cysteines of ANT1, unlocking the mechanism of ANT1-mediated uncoupling [361] and enabling cardioprotection [360]. The molecular mechanism behind the ANT1-Cys ${ }^{57}$ nitroalkylation and uncoupling seems to be the conjugation of nitro-linoleate to its mitochondriotropic triphenylphosphonium moiety [362].

Modulation of complex III (ubiquinol:cytochrome c oxidoreductase) in the context of IRI, however, has not attracted much attention for a long time. To our knowledge, demonstrations of cardioprotection by inhibition of the ubiquinol oxidation center (center $\mathrm{P}, \mathrm{Q}_{\mathrm{o}}$ site) at complex III with myxothiazol were last published almost 20 years ago [363,364]. It seems that the most promising mechanism being explored is the ROS production via $Q_{o}$ site not as an oxidative agent, but as an important second messenger for mechanisms of adaptation to hypoxia [365]. This pathway seems to participate in cardioprotection by pre-ischemic conditioning in the rat [366], probably by inducing hypoxic stabilization of hypoxia-inducible factor 1-alpha (HIF-1 $\alpha)[367,368]$ and enabling transcription of protecting factors, including the earlier discussed erythropoietin and VEGF [369].

Interestingly, regarding the typical respiratory activity, reduced cytochrome $\mathrm{c}$ acts as an electron carrier from complex III to IV, and the reaction direction is unfavorable to superoxide production at the complex III $Q_{o}$ site. However, under RET, the cytochrome c pool is oxidized, becoming an effective ROS scavenger medium [365], which appears to be a rather underexplored mechanism with the potential for IRI attenuation.

It is worth citing the complex III inhibitor antimycin A, which is an important compound frequently used to induce chemical hypoxia and aid IRI studies. It blocks the physiological net electron transfer in the respiratory chain by inhibition of complex III by conjugation with the Qi site [249]. This condition triggers the oxidant-induced reduction state of $Q_{O}$ site, shifts the redox of the Q-pool and, in turn, donate electrons to molecular oxygen, intensifying ROS production [370].

The interactions among different respiration complex modulators is a recurrent issue and should always be taken into account before any therapeutic intervention. For instance, the use of complex III inhibitors (e.g., antimycin A) along with complex II inhibitors (i.e., malonate, oxaloacetate or diazoxide) should be used with discretion if there is a prospect of hypoxia. In this setting, complex II inhibitors can expand their affinity to the $Q_{o}$ site of complex III, and with the $Q_{i}$ site of complex III already blocked, there would be a complete loss of the capability for cytochrome $b$ reoxidation, ultimately leading to an increase in ROS synthesis and an intensification of the oxidative stress [349]. Also stigmatellin and myxothiazol (both known to block $Q_{o}$ site of complex III) can also inhibit the rotenone binding site at complex I, leading to yet another anomalous ROS output [249].

It is wise not to rule out the likely possibility that many positive results that are yet not fully understood could be attributed to a pleiotropic effect of these drugs, which would reduce inhibition of respiratory complexes to a mere unsettling side-effect.

\subsection{Engaging Multiple Pathways}

Although many of the known IRI-protecting drugs are thought to act upon one or few cell signaling pathways, it is very likely that most of them modulate a cascade of pathways, in ways that the pharmacological research has not yet unveiled. It is true that, in many cases, particular drugs regulate multiple pathways in such an evenly fashion, that it would be unwise to reduce the whole mechanism of action to a narrower reductionist view. Newer findings in IRI regulation regarding the mammalian sirtuins, as recently reviewed by Pantazi et al. [6], adequately illustrate this fact. The sirtuins are a highly conserved family of class III histone deacetylases, consisting of seven members of regulatory enzymes (SIRT1 to SIRT7) that are fundamental for many cellular processes including gene silencing, DNA repair, and metabolic regulation [6,155,371]. Age-related DNA damage tends to 
induce deficient expression of mitochondrial sirtuins (SIRT1 and SIRT3), a fact that is strongly correlated with lower stress resistance (by NAD ${ }^{+}$depletion) [372] and increased IRI in the rat myocardium [373]. Not surprisingly, the upregulation of SIRT1 in mice elicits all sorts of health benefits, such as reduced incidence of cardiovascular and metabolic diseases [155,374]. Also, the mitochondrial sirtuin (SIRT3) can act as an antioxidant and deacetylate the cyclophilin D of the $\mathrm{MPTP}$, reducing mitochondrial swelling by IRI in the myocardium [6]. The upregulation of SIRT1 by lumbrokinase [375] or SIRT3 by melatonin [174] was also demonstrated to be cardioprotective against IRI in the mice.

In this context, resveratrol, a renowned bioactive polyphenol found in red wine [157], is one of such compounds that fit into the category of multiple pathways stimulation. Recent data by Price et al. shows that resveratrol can stimulate the activation of AMPK, which, in turn, has a relation of positive feedback with SIRT1, ultimately leading to activation of the mTOR and NF-KB pathways, both in vitro and in vivo [155]. However, Athar et al. [156] have reported that resveratrol can also reduce the levels of damage-associated cytokines (TNF- $\alpha$ and IL-1 $\beta$ ), while at the same time increasing protecting factors (Toll-like receptor 4 and the inhibitor of NF-KB: IKB- $\alpha$ ) caused by IRI in liver tissues [156].

$\mathrm{Li}$ et al. [376] used bioinformatics to analyze grouped databases of topological ligand-target information and to identify core therapeutic targets in colorectal cancer that intersect with those targeted by resveratrol. After the structural screening for predicting protein interactions, they used information about biological function and pathway enrichment to derive the function from the structure of each complex. They isolated five cores of potential therapeutic targets of resveratrol and anti-colorectal cancer drugs along the following pathways: RISK (AKT1), SAFE (IL6, VEGF), MAPK 1, and pathways involving tumor protein p53 [376]. Moreover, as suggested experimentally, resveratrol also might have additional multiple targets in SAFE, RISK, cGMP, among others, acting upon COX, PDEs, PI3K, ER $\alpha / \beta$, or p70S6K [158]. The fact that the authors achieved such close convergence between theoretical and experimental research is exciting and certainly supports the value of the interplay between those fields.

Another compound that shows outstanding protection against IRI via multiple pathways is hydrogen sulfide $\left(\mathrm{H}_{2} \mathrm{~S}\right)$. Perhaps it is no exaggeration to state that its structural simplicity may very well be considered as inversely proportional to the number of ways it can grant protection. Hydrogen sulfide's vast repertoire of protective mechanisms against IRI range from a direct antioxidant effect [259] to maintenance of physiological homeostasis, stimulation of anti-inflammatory pathways, insulin release, and angiogenesis [255], activation of the RISK pathway, and mitochondrial protection by limiting $\mathrm{mPTP}$ opening and upregulating $\mathrm{mK}_{\mathrm{ATP}}$ [256]. An evident drawback of $\mathrm{H}_{2} \mathrm{~S}$ is that it is naturally a gaseous element, a fact that can pose some delivery problems. Therefore it is frequently employed therapeutically in the form of more chemically stable exogenous $\mathrm{H}_{2} \mathrm{~S}$ donor compounds (sulfide salts) such as sodium sulfide $\left(\mathrm{Na}_{2} \mathrm{~S}\right)$ and sodium hydrogen sulfide (NaHS) [257]. However, sulfide salts may present solubility, volatilization or an anomalous concentration and rate release $\mathrm{H}_{2} \mathrm{~S}[257,258]$. In view of these questions, researchers have been using the class of synthetic $\mathrm{H}_{2} \mathrm{~S}$ donors, that can be released to the target in more refined ways than those displayed by the disulfide salts. In this class, GYY4137, a phosphinodithioate derived from the Lawesson's reagent, is a slow $\mathrm{H}_{2}$ S-releasing compound with vasodilation and antihypertensive effects [258] with an excellent possibility of being IRI-protective. A targeted release is also an advantage of these synthetic drugs. AP39 induces selective $\mathrm{H}_{2} \mathrm{~S}$ release to the mitochondria [261] and when applied at reperfusion has shown protection from $\mathrm{I} / \mathrm{R}$ insults to the mouse brain [262] and kidney [263]. Kang et al. describe a group of chemicals that use the naturally acidic environment of ischemic tissues to employ intramolecular cyclization and targeted $\mathrm{H}_{2} \mathrm{~S}$ liberation [260]. On the other hand, endogenous $\mathrm{H}_{2} \mathrm{~S}$ stimulation with positive results has been achieved with zofenopril in the myocardium [259]

\subsection{Alternative Mechanisms of Protection}

Several anti-inflammatory and/or anti-apoptotic agents act on numerous biochemical pathways differing from those involved in a well-delineated intra-cellular pathway. These agents may directly inhibit/attenuate inflammatory responses by various mechanisms that may involve reducing the 
activation and adhesion of leucocytes, modulation of NO, setting autophagy to priority over apoptosis, inhibition of inflammasome pathways and others. Among many well-tolerated and safe drugs and mediators, we highlight the good results obtained with methylprednisolone [145], ulinastatin [146,147], adaravone [178], aripiprazole [146], flurbiprofen axetil [377], neutrophil gelatinase-associated lipocalin [159], exogenous NGAL [160], and Ghrelin [161-164].

The class of antioxidants is also one that has been repeatedly shown to be protective against IRI by downregulating many inflammatory pathways. The mechanisms vary greatly and may be roughly summarized as activation of protective pathways (mostly suppression of mitophagy) and neutralization of free radicals and other reactive oxidizing species. Some prominent agents are aldehyde dehydrogenase 2 [165-167,169,170], candesartan [153], minocycline [153,172], melatonin [97,173,174,177,225], exogenous NADPH [378], glutathione [96,98,179,180,379], $N$-acetylcysteine (NAC) [98,180-184], calmangafodipir [185], mangafodipir [185-187], superoxide dismutase [188-192], diltiazem [191], idebenone [193], rasagiline, and idebenone [194].

One can also employ angiogenesis stimulation in order to increase the perfusion to the tissue and better prepare it for the IR stress. As such, one of the first-line drugs for the treatment of type 2 diabetes, metformin has been consistently showing positive effects [53,152-154]. Its primary therapeutic effect is that of a hypoglycemic agent that inhibits hepatic gluconeogenesis, increases insulin action on peripheral glucose uptake and consequently prevents many vascular and neurologic complications. Although these beneficial effects are well-delineated, it has been shown that the pleiotropic angiogenic effects of metformin can be a useful tool for the enhancement of tissue perfusion and the minimization of hypoxia of skin flaps [53] and myocardial tissue [154]. These beneficial effects were confirmed by another study with a drop of up to $30 \%$ in the incidence of macrovascular diseases compared with other treatment modalities [152]. The suggested mechanism of cardioprotection by metformin treatment is due to upregulation of the activity of NO synthase [153]. Koutsogiannidis and Johnson also demonstrated a significant synergy of metformin and sub-therapeutic doses of L-arginine, achieving the same effects with a lower concentration of metformin. The authors claim that these findings can be of particular importance for diabetic patients undergoing reconstructive plastic surgery [53]. Similarly, by employing candesartan as an antagonist of the angiotensin II type 1 receptor, Kozak et al. achieved [154] protection of porcine myocardium from IRI. They stated that the post-reperfusion use of candesartan promotes increasing in matrix metalloproteinase-2 (MMP-2) activity and vascular endothelial growth factor (VEGF) expression in the myocardium, inducing the establishment of the angiogenic state induced by ischemia earlier than usual and therefore enhancing vascular protection.

Another sound strategy against IRI described in the literature is the use of glucose metabolism enhancers, leading to both increased glucose catabolism and uptake by the cell before the ischemic "starvation" state. Drugs in this category may share different means but to a common end, i.e., shifting cellular energy metabolism from fatty acid $\beta$-oxidation to glucose oxidation $[99,100]$. The resulting hyperglycemia is often remarkably complemented by the stimulus of translocation of intracellular GLUT4 to the cell surface, ultimately leading to increased ATP synthesis, reduced oxygen consumption and better tolerance to hypoxia [145]. Myocardial infarction size due to IRI is successfully attenuated with the use of trimetazidine, an antianginal drug that selectively inhibits long-chain 3-ketoacyl-co-enzyme A (CoA) thiolase (3-KAT) and regulates both the AMPK and RISK signaling pathways [99-101]. In heart failure treatment, however, the efficacy of trimetazidine efficacy seems to, indeed derive from a pleiotropic mechanism [380]. Malek et al. also described cardioprotection from IRI as a result of the stimulation of hyperglycemia, by downregulation of the ubiquitin-proteosome system via the selective inhibitors lactacystin and MG-132 [150]. Interestingly, they also found that these inhibitors enhanced SOD1 and SOD2 levels, lowering peroxidation and thus attenuating inflammation and upregulating autophagy markers. Nadtochiy et al. showed that the $\mathrm{NAD}^{+}$precursor, nicotinamide mononucleotide, is cardioprotective both via stimulation of the glycolytic pathway and enhanced ATP synthesis during ischemia and/or enhanced acidosis at reperfusion [381]. 
The switch to glucose oxidation can also be achieved with drugs from the class of carnitine palmitoyltransferase-1 (CPT-1) inhibitors [195,196], and have been presenting success in myocardial protection in IRI in animal models: oxfenicine [197-200], etomoxir [201,202], and perhexiline [203-205]. However, due to safety concerns, recent literature reports have shown controversy about the use of CPT-1 inhibitors in the context of IRI in humans. For almost two decades, etomoxir has been under harsh criticism due to important adverse effects such as severe hepatotoxicity [204] and acute oxidative stress in proliferating $\mathrm{T}$ cells [202], rendering this drug a discouraging perspective for clinical use in the immediate future. On the other hand, despite compelling criticism $[100,205]$, perhexiline and oxfenicine seem to be gaining strength about their safety and clinical uses [205,380,382], being recently approved as antianginal agents in Australia, Canada, and some parts of Asia [383,384].

As already cited above, reperfusion after ischemia triggers a particular set of potential damaging mechanisms, and an eventful one is the activation of matrix metalloproteinases (MMP), a class that comprises, among others, gelatinases (MMP-2 and -9) and collagenases (MMP-8 and -13) [385]. MMPs are important regulators of several metabolic mechanisms such as the extracellular matrix remodeling, and also regulate immune responses [386], blood-brain barrier maintenance, and regenerative and structural repairing after IRI in the brain [385]. However, in the pathological context of I/R, MMPs may promote the degradation of intracellular proteins and lead to structural and functional impairment, as we previously stated in this review. Therefore, the rational use of MMP-inhibitors against IRI seems to be a reasonable, and certainly plausible strategy upon reperfusion. Unfortunately, many earlier MMP-inhibitors were found to have too broad a spectrum of action [387], which defeats the purpose of specificity of a pharmacological agent, therefore and further studies are necessary in order to develop more specific targeting [220,386]. Nevertheless, in experimental settings, MMP inhibition has been continuously demonstrated to attenuate IRI, even independently of classic pathways such as the RISK/SAFE pathway or even via direct mPTP involvement [221]. Ilomastat, a first-generation inhibitor of MMPs that belongs to the class of catalytic zinc-targeting inhibitors [387], has been proven to engender protection in mouse myocardium upon IRI [221]. Recently, pharmacological MPP inhibition was also successful in alleviating IRI markers with the use of an MMP-8-inhibitor [222], liver-selective (but not systemic) MMP-9 inhibition [223], and o-phenanthroline [224].

Apart from direct MMP-inhibitors, other pharmaceuticals such as tetracycline antibiotics, statins, COX inhibitors, and melatonin (especially when administered in nanocapsules [225]) have all been linked to the indirect modulation of MMPs activity [220]. For instance, Cortes et al. were able to protect glomerular function from IRI after intraperitoneal administration of low-dose of doxycycline ( $3 \mathrm{mg} / \mathrm{kg}$ ) [226] by using it as a $\mathrm{Zn}^{2+}$ chelation agent instead of its routine antibacterial indication. Similarly, minocycline, when used as an MPP-inhibitor along with an angiogenic agent, also elicited protection against experimental stroke in rats [153].

\subsection{Hyperbaric Oxygen Therapy}

Although its mechanism of action is not fully understood and not a pharmacological approach per se, hyperbaric oxygen therapy ( $\mathrm{HBO})$ is a useful complement in the treatment of ischemia and reperfusion injury in various organs [13] and is worth mentioning. By increasing circulating and tissue oxygen saturation, hyperbaric oxygen preconditioning reduces the effects of hypoxic lesions, attenuating the inflammatory response in the initial phases of IR $[13,388,389]$. Functionally, HBO reduces neutrophil adhesion and post-ischemic vasoconstriction by enhancing tissue blood perfusion and increases the oxygen gradient at the periphery of the ischemic areas by promoting angiogenesis. In addition, it stimulates the increase of several growth factors, elevates the activity of catalase and superoxide dismutase (systemic antioxidant agents), alters the synthesis of cytokines by monocytes and increases the synthesis of heat shock proteins, where HSP70 (an anti-apoptotic protein) gains the spotlight, minimizing the deleterious effects of ischemia. All of these events attenuate ischemia and reperfusion injury in patients exposed to preconditioning hyperbaric oxygen therapy $[13,14,389,390]$. HBO promotes systemic effects: it reduces the demand for hemoglobin, increases blood oxygenation, 
and exhibits antibacterial effects with bacteriostatic or bactericidal activities. It also induces the formation of oxidizing agents producing peroxynitrite from the reaction of superoxide with nitric oxide, thus having a systemic vasoconstriction property. Although it has a potential therapeutic role in the presence of inflammatory and ischemic events, the supply of oxygen to healthy tissues may lead to undesirable cellular effects depending on the protocol used, such as atelectasis and toxicity in the lungs, systemic redox reactions with increased production of ROS and systemic vasoconstriction [391].

\section{Conclusions and Perspectives}

The theories and conclusions based on some three decades or more of research did not, unfortunately, lead to a definitive solution for the prevention and treatment of the ischemia-reperfusion injury. It seems clear that the basic and clinical sciences should insist on prevention methods and confirm that attacking the early reperfusion is a goal to be pursued. The endorsement of the literature that the underlying mechanisms of reperfusion injury seem to be shared among heart, brain, liver, intestine, skeletal muscle and more, has contributed significantly to unifying the understanding of the subject. The cardiology, the specialty that currently benefits the most from the research on IRI, saw the establishment of the techniques of thrombolytic reperfusion in myocardial infarction as one of the major acquisitions of modern medicine, and now it eagerly awaits the incorporation of many great laboratory finds into the clinical practice. Although the present review has focused on the problem of IRI from the point of view of pharmacological interventionists, there are still many more effective forms of protection to be explored, and we encourage the reader to check out the excellent reviews we cited here.

Author Contributions: Conceptualization, O.C.-e.-S. and P.É.; methodology, O.C.-e.-S.; investigation, R.O.S.S., D.M.L., M.C.J., P.É. and O.C.-e.-S.; writing-original draft preparation, R.O.S.S and P.É.; writing—review and editing, R.O.S.S., D.M.L., M.C.J., P.É. and O.C.-e.-S.; visualization, R.O.S.S. and P.É.; supervision, O.C.-e.-S. and P.É.; project administration, O.C.-e.-S.; funding acquisition, O.C.-e.-S.

Funding: Both research and APC were funded by Fundação de Amparo à Pesquisa do Estado de São Paulo (FAPESP), grant number 2013/07276-1.

Acknowledgments: The authors acknowledge the source of funding.

Conflicts of Interest: The authors declare no conflict of interest.

\section{References}

1. Carden, D.L.; Granger, D.N. Pathophysiology of ischaemia-reperfusion injury. J. Pathol. 2000, 190, 255-266. [CrossRef]

2. Evora, P.R.; Pearson, P.J.; Schaff, H.V. Endothelial function and coronary vasospasm after heart surgery. Arq. Bras. Cardiol. 1993, 61, 119-125. [PubMed]

3. Evora, P.R.; Pearson, P.J.; Seccombe, J.F.; Schaff, H.V. Ischemia-reperfusion lesion. Physiopathologic aspects and the importance of the endothelial function. Arq. Bras. Cardiol. 1996, 66, 239-245. [PubMed]

4. Evora, P.R.; Pearson, P.J.; Schaff, H.V. Impaired endothelium-dependent relaxation after coronary reperfusion injury: Evidence for G-protein dysfunction. Ann. Thorac. Surg. 1994, 57, 1550-1556. [CrossRef]

5. Ibanez, B.; Heusch, G.; Ovize, M.; Van De Werf, F. Evolving Therapies for Myocardial Ischemia/Reperfusion Injury. J. Am. Coll. Cardiol. 2015, 65, 1454-1471. [CrossRef]

6. Pantazi, E.; Zaouali, M.A.; Bejaoui, M.; Folch-Puy, E.; Ben Abdennebi, H.; Roselló-Catafau, J. Role of sirtuins in ischemia-reperfusion injury. World J. Gastroenterol. 2013, 19, 7594-7602. [CrossRef] [PubMed]

7. Nastos, C.; Kalimeris, K.; Papoutsidakis, N.; Tasoulis, M.-K.; Lykoudis, P.M.; Theodoraki, K.; Nastou, D.; Smyrniotis, V.; Arkadopoulos, N. Global Consequences of Liver Ischemia/Reperfusion Injury. Oxidative Med. Cell. Longev. 2014, 2014, 1-13. [CrossRef]

8. Hentia, C.; Rizzato, A.; Camporesi, E.; Yang, Z.; Muntean, D.M.; Săndesc, D.; Bosco, G. An overview of protective strategies against ischemia/reperfusion injury: The role of hyperbaric oxygen preconditioning. Brain Behav. 2018, 8, e00959. [CrossRef] 
9. Kumar, V.; Abbas, A.K.; Aster, J.C. Robbins and Cotran Pathologic Basis of Disease, 9th ed.; Elsevier: Amsterdam, The Netherlands, 2015.

10. Swärdh, A.; Sjöquist, P.; Wang, Q. Relationship between ischaemic time and ischaemia/reperfusion injury in isolated Langendorff-perfused mouse hearts. Acta Physiol. Scand. 2001, 171, 123-128.

11. Hasche, E.T.; Fernandes, C.; Ben Freedman, S.; Jeremy, R.W.; Freedman, S.B. Relation between Ischemia Time, Infarct Size, and Left Ventricular Function in Humans. Circulation 1995, 92, 710-719. [CrossRef]

12. Reimer, K.A.; Lowe, J.E.; Rasmussen, M.M.; Jennings, R.B. The wavefront phenomenon of ischemic cell death. 1. Myocardial infarct size vs. duration of coronary occlusion in dogs. Circulation 1977, 56, 786-794. [CrossRef] [PubMed]

13. Wu, H.-H.; Huang, C.-C.; Chang, C.-P.; Lin, M.-T.; Niu, K.-C.; Tian, Y.-F. Heat Shock Protein 70 (HSP70) Reduces Hepatic Inflammatory and Oxidative Damage in a Rat Model of Liver Ischemia/Reperfusion Injury with Hyperbaric Oxygen Preconditioning. Med. Sci. Monit. 2018, 24, 8096-8104. [CrossRef] [PubMed]

14. Lee, P.J.; Choi, A.M.K. Pathways of cell signaling in hyperoxia. Free Radic. Boil. Med. 2003, 35, 341-350. [CrossRef]

15. Lin, Y.W.; Chen, T.Y.; Hung, C.Y.; Tai, S.H.; Huang, S.Y.; Chang, C.C.; Hung, H.Y.; Lee, E.J. Melatonin protects brain against ischemia/reperfusion injury by attenuating endoplasmic reticulum stress. Int. J. Mol. Med. 2018, 42, 182-192. [CrossRef] [PubMed]

16. Zhou, H.; Zhu, J.; Yue, S.; Lu, L.; Busuttil, R.W.; Kupiec-Weglinski, J.W.; Wang, X.; Zhai, Y.; Zhou, H. The Dichotomy of Endoplasmic Reticulum Stress Response in Liver Ischemia-Reperfusion Injury. Transplantation 2016, 100, 365-372. [CrossRef] [PubMed]

17. Nakka, V.P.; Gusain, A.; Raghubir, R. Endoplasmic reticulum stress plays critical role in brain damage after cerebral ischemia/reperfusion in rats. Neurotox. Res. 2010, 17, 189-202. [CrossRef]

18. De Almeida, T.N.; Victorino, J.P.; Bistafa Liu, J.; Tofoli Queiroz Campos, D.; Graf, C.; Jordani, M.C.; Carneiro d'Albuquerque, L.A.; Mendes, K.D.S.; Castro, E.S.O. Effect of Hepatic Preconditioning with the Use of Methylene Blue on the Liver of Wistar Rats Submitted to Ischemia and Reperfusion. Transplant. Proc. 2018, 50, 841-847. [CrossRef]

19. Peralta, C.; Gracia-Sancho, J.; Casillas-Ramírez, A.; Gracia-Sancho, J.; Casillas-Ramírez, A.; Gracia-Sancho, J.; Casillas-Ramirez, A. Molecular pathways in protecting the liver from ischaemia/reperfusion injury: A 2015 update. Clin. Sci. 2015, 129, 345-362.

20. Zoratti, M.; Szabò, I. The mitochondrial permeability transition. Biochim. Biophys. Acta BBA Rev. Biomembr. 1995, 1241, 139-176. [CrossRef]

21. Teoh, N.C.; Farrell, G.C. Hepatic ischemia reperfusion injury: Pathogenic mechanisms and basis for hepatoprotection. J. Gastroenterol. Hepatol. 2003, 18, 891-902. [CrossRef]

22. Guan, L.-Y.; Fu, P.-Y.; Li, P.-D.; Li, Z.-N.; Liu, H.-Y.; Xin, M.-G.; Li, W. Mechanisms of hepatic ischemia-reperfusion injury and protective effects of nitric oxide. World J. Gastrointest. Surg. 2014, 6, 122-128. [CrossRef] [PubMed]

23. Datta, G.; Fuller, B.J.; Davidson, B.R. Molecular mechanisms of liver ischemia reperfusion injury: Insights from transgenic knockout models. World J. Gastroenterol. 2013, 19, 1683-1698. [CrossRef] [PubMed]

24. Lu, L.; Zhou, H.; Ni, M.; Wang, X.; Busuttil, R.; Kupiec-Weglinski, J.; Zhai, Y. Innate Immune Regulations and Liver Ischemia-Reperfusion Injury. Transplantation 2016, 100, 2601-2610. [CrossRef] [PubMed]

25. Lin, X.; Xiao, W.; Xiao, L.; Liu, M. Molecular mechanisms of autophagy in cardiac ischemia/reperfusion injury (Review). Mol. Med. Rep. 2018, 18, 675-683. [CrossRef] [PubMed]

26. Ma, S.; Wang, Y.; Chen, Y.; Cao, F. The role of the autophagy in myocardial ischemia/reperfusion injury. Biochim. Biophys. Acta BBA Mol. Basis Dis. 2015, 1852, 271-276. [CrossRef] [PubMed]

27. Aghaei, M.; Motallebnezhad, M.; Ghorghanlu, S.; Jabbari, A.; Enayati, A.; Rajaei, M.; Pourabouk, M.; Moradi, A.; Alizadeh, A.M.; Khori, V. Targeting autophagy in cardiac ischemia/reperfusion injury: A novel therapeutic strategy. J. Cell. Physiol. 2019, 234, 16768-16778. [CrossRef]

28. Zhang, X.; Yan, H.; Yuan, Y.; Gao, J.; Shen, Z.; Cheng, Y.; Shen, Y.; Wang, R.-R.; Wang, X.; Hu, W.-W.; et al. Cerebral ischemia-reperfusion-induced autophagy protects against neuronal injury by mitochondrial clearance. Autophagy 2013, 9, 1321-1333. [CrossRef]

29. Chouchani, E.T.; Pell, V.R.; James, A.M.; Work, L.M.; Saeb-Parsy, K.; Frezza, C.; Krieg, T.; Murphy, M.P. A Unifying Mechanism for Mitochondrial Superoxide Production during Ischemia-Reperfusion Injury. Cell Metab. 2016, 23, 254-263. [CrossRef] 
30. Chouchani, E.T.; Pell, V.R.; Gaude, E.; Aksentijević, D.; Sundier, S.Y.; Robb, E.L.; Logan, A.; Nadtochiy, S.M.; Ord, E.N.J.; Smith, A.C.; et al. Ischaemic accumulation of succinate controls reperfusion injury through mitochondrial ROS. Nature 2014, 515, 431-435. [CrossRef]

31. Murphy, M.P. How mitochondria produce reactive oxygen species. Biochem. J. 2009, 417, 1-13. [CrossRef]

32. Pell, V.R.; Chouchani, E.T.; Frezza, C.; Murphy, M.P.; Krieg, T. Succinate metabolism: A new therapeutic target for myocardial reperfusion injury. Cardiovasc. Res. 2016, 111, 134-141. [CrossRef] [PubMed]

33. Hollander, J.M.; Thapa, D.; Shepherd, D.L. Physiological and structural differences in spatially distinct subpopulations of cardiac mitochondria: Influence of cardiac pathologies. Am. J. Physiol. Circ. Physiol. 2014, 307, H1-H14. [CrossRef] [PubMed]

34. Javadov, S.; Jang, S.; Parodi-Rullan, R.; Khuchua, Z.; Kuznetsov, A.V. Mitochondrial permeability transition in cardiac ischemia-reperfusion: Whether cyclophilin D is a viable target for cardioprotection? Cell. Mol. Life Sci. CMLS 2017, 74, 2795-2813. [CrossRef] [PubMed]

35. Fels, J.A.; Manfredi, G. Sex Differences in Ischemia/Reperfusion Injury: The Role of Mitochondrial Permeability Transition. Neurochem. Res. 2019, 44, 2336-2345. [CrossRef] [PubMed]

36. Casin, K.M.; Fallica, J.; Mackowski, N.; Veenema, R.J.; Chan, A.; Paul, A.S.; Zhu, G.; Bedja, D.; Biswal, S.; Kohr, M.J. S-Nitrosoglutathione Reductase Is Essential for Protecting the Female Heart From Ischemia-Reperfusion Injury. Circ. Res. 2018, 123, 1232-1243. [CrossRef] [PubMed]

37. Laslett, L.J.; Alagona, P., Jr.; Clark, B.A., 3rd; Drozda, J.P., Jr.; Saldivar, F.; Wilson, S.R.; Poe, C.; Hart, M. The worldwide environment of cardiovascular disease: Prevalence, diagnosis, therapy, and policy issues: A report from the American College of Cardiology. J. Am. Coll. Cardiol. 2012, 60 (Suppl. 25), S1-S49. [CrossRef]

38. Cohen, M.V.; Yang, X.-M.; Downey, J.M. Smaller infarct after preconditioning does not predict extent of early functional improvement of reperfused heart. Am. J. Physiol. Circ. Physiol. 1999, 277, H1754-H1761. [CrossRef] [PubMed]

39. Eisen, A.; Fisman, E.Z.; Rubenfire, M.; Freimark, D.; McKechnie, R.; Tenenbaum, A.; Motro, M.; Adler, Y. Ischemic preconditioning: Nearly two decades of research. A comprehensive review. Atherosclerosis 2004, 172, 201-210. [CrossRef]

40. Schultz, J.E.J.; Hsu, A.K.; Barbieri, J.T.; Li, P.-L.; Gross, G.J. Pertussis toxin abolishes the cardioprotective effect of ischemic preconditioning in intact rat heart. Am. J. Physiol. Circ. Physiol. 1998, 275, H495-H500. [CrossRef]

41. Waterson, R.E.; Thompson, C.G.; Mabe, N.W.; Kaur, K.; Talbot, J.N.; Neubig, R.R.; Rorabaugh, B.R. Galpha(i2)-mediated protection from ischaemic injury is modulated by endogenous RGS proteins in the mouse heart. Cardiovasc. Res. 2011, 91, 45-52. [CrossRef]

42. Kohler, D.; Devanathan, V.; Bernardo de Oliveira Franz, C.; Eldh, T.; Novakovic, A.; Roth, J.M.; Granja, T.; Birnbaumer, L.; Rosenberger, P.; Beer-Hammer, S.; et al. Galphai2- and Galphai3-deficient mice display opposite severity of myocardial ischemia reperfusion injury. PLoS ONE 2014, 9, e98325. [CrossRef] [PubMed]

43. Parra, S.; Huang, X.Y.; Charbeneau, R.A.; Wade, S.M.; Kaur, K.; Rorabaugh, B.R.; Neubig, R.R. Conditional disruption of interactions between $\mathrm{Ga}-\mathrm{i} 2$ and regulator of $\mathrm{G}$ protein signaling (RGS) proteins protects the heart from ischemic injury. BMC Pharmacol. Toxicol. 2014, 15, 29. [CrossRef] [PubMed]

44. Stewart, A.; Huang, J.; Fisher, R.A. RGS Proteins in Heart: Brakes on the Vagus. Front. Physiol. 2012 , 3, 95. [CrossRef]

45. Yang, J.; Maity, B.; Huang, J.; Gao, Z.; Stewart, A.; Weiss, R.M.; Anderson, M.E.; Fisher, R.A. G-protein inactivator RGS6 mediates myocardial cell apoptosis and cardiomyopathy caused by doxorubicin. Cancer Res. 2013, 73, 1662-1667. [CrossRef] [PubMed]

46. Rorabaugh, B.R.; Chakravarti, B.; Mabe, N.W.; Seeley, S.L.; Bui, A.D.; Yang, J.Q.; Watts, S.W.; Neubig, R.R.; Fisher, R.A. Regulator of G Protein Signaling 6 Protects the Heart from Ischemic Injury. J. Pharmacol. Exp. Ther. 2017, 360, 409-416. [CrossRef]

47. Evora, P.R.B. G-Proteins Agonists and NO/cGMP Blockers: Unexplored Frontiers in the Pharmaceutical Industry. Arq. Bras. Cardiol. 2017, 109, 275-276. [CrossRef] [PubMed]

48. Evora, P.R.B.; Nobre, F. The role of G-proteins in the pathophysiology of the cardiovascular diseases. Arq. Bras. Cardiol. 1999, 72, 209-229. [CrossRef] 
49. Vilalva, K.H.; Mumic, F.T.; Silveira, M.R.G.; Mente, E.D.; Evora, P.R.B.; Castro, E.S.O. Use of Methylene Blue to Treat Hypovolemic Shock Followed by Ischemia-Reperfusion Injury in the Postoperative Orthotopic Liver Transplant Patient: A Case Report. Exp. Clin. Transplant. 2018, 16, 511-514.

50. Chies, A.B.; Nakazato, P.C.G.; Spadella, M.A.; Zorzi, P.; Gomes, M.C.J.; D’Albuquerque, L.A.C.; Castro-E-Silva, O. Rivastigmine prevents injury induced by ischemia and reperfusion in rat liver. Acta Cir. Bras. 2018, 33, 775-784. [CrossRef]

51. Nakazato, P.C.G.; Victorino, J.P.; Fina, C.F.; Mendes, K.D.S.; Gomes, M.C.J.; Evora, P.R.B.; D'Albuquerque, L.A.C.; Castro-E-Silva, O. Liver ischemia and reperfusion injury. Pathophysiology and new horizons in preconditioning and therapy. Acta Cir. Bras. 2018, 33, 723-735. [CrossRef]

52. Wu, H.; Chen, G.; Wyburn, K.R.; Yin, J.; Bertolino, P.; Eris, J.M.; Alexander, S.I.; Sharland, A.F.; Chadban, S.J. TLR4 activation mediates kidney ischemia/reperfusion injury. J. Clin. Investig. 2007, 117, 2847-2859. [CrossRef] [PubMed]

53. Koutsogiannidis, C.P.; Johnson, E.O. Pharmacological Neuroprotection in Cardiac Surgery: Effectiveness of Pharmacologic-Preconditioning with Erythromycin. Curr. Vasc. Pharmacol. 2018, 16, 329-335. [CrossRef] [PubMed]

54. De Perrot, M.; Liu, M.; Waddell, T.K.; Keshavjee, S. Ischemia-Reperfusion-induced Lung Injury. Am. J. Respir. Crit. Care Med. 2003, 167, 490-511. [CrossRef] [PubMed]

55. Eppinger, M.J.; Deeb, G.M.; Bolling, S.F.; Ward, P.A. Mediators of ischemia-reperfusion injury of rat lung. Am. J. Pathol. 1997, 150, 1773-1784. [PubMed]

56. Weiser, M.R. Reperfusion injury of ischemic skeletal muscle is mediated by natural antibody and complement. J. Exp. Med. 1996, 183, 2343-2348. [CrossRef] [PubMed]

57. Menger, M.D.; Pelikan, S.; Steiner, D.; Messmer, K. Microvascular ischemia-reperfusion injury in striated muscle: Significance of "reflow paradox". Am. J. Physiol. Circ. Physiol. 1992, 263, H1901-H1906. [CrossRef] [PubMed]

58. Junk, A.K.; Mammis, A.; Savitz, S.I.; Singh, M.; Roth, S.; Malhotra, S.; Rosenbaum, P.S.; Cerami, A.; Brines, M.; Rosenbaum, D.M. Erythropoietin administration protects retinal neurons from acute ischemia-reperfusion injury. Proc. Natl. Acad. Sci. USA 2002, 99, 10659-10664. [CrossRef]

59. Oharazawa, H.; Igarashi, T.; Yokota, T.; Fujii, H.; Suzuki, H.; Machide, M.; Takahashi, H.; Ohta, S.; Ohsawa, I. Protection of the Retina by Rapid Diffusion of Hydrogen: Administration of Hydrogen-Loaded Eye Drops in Retinal Ischemia-Reperfusion Injury. Investig. Ophthalmol. Vis. Sci. 2010, 51, 487-492. [CrossRef]

60. Oliver, C.N.; Starke-Reed, P.E.; Stadtman, E.R.; Liu, G.J.; Carney, J.M.; Floyd, R.A. Oxidative damage to brain proteins, loss of glutamine synthetase activity, and production of free radicals during ischemia/reperfusion-induced injury to gerbil brain. Proc. Natl. Acad. Sci. USA 1990, 87, 5144-5147. [CrossRef]

61. Santos, M.R.; Celotto, A.C.; Capellini, V.K.; Evora, P.R.B.; Piccinato, C.E.; Joviliano, E.E. The protective effect of cilostazol on isolated rabbit femoral arteries under conditions of ischemia and reperfusion: The role of the nitric oxide pathway. Clinics 2012, 67, 171-178. [CrossRef]

62. Ciscato, J.G.; Capellini, V.K.; Celotto, A.C.; Baldo, C.F.; Joviliano, E.E.; Evora, P.R.; Dalio, M.B.; Piccinato, C.E. Vascular relaxation of canine visceral arteries after ischemia by means of supraceliac aortic cross-clamping followed by reperfusion. Scand. J. Trauma Resusc. Emerg. Med. 2010, 18, 41. [CrossRef] [PubMed]

63. Cerqueira, N.F.; Hussni, C.A.; Yoshida, W.B. Pathophysiology of mesenteric ischemia/reperfusion: A review. Acta Cir. Bras. 2005, 20, 336-343. [CrossRef] [PubMed]

64. Hochman, J.S. Cardiogenic shock complicating acute myocardial infarction: Expanding the paradigm. Circulation 2003, 107, 2998-3002. [CrossRef] [PubMed]

65. Cotter, G.; Kaluski, E.; Milo, O.; Blatt, A.; Salah, A.; Hendler, A.; Krakover, R.; Golick, A.; Vered, Z. LINCS: L-NAME (a NO synthase inhibitor) in the treatment of refractory cardiogenic shock: A prospective randomized study. Eur. Heart J. 2003, 24, 1287-1295. [CrossRef]

66. De Castro-e-Silva, O.; Centurion, S.; Pacheco, E.G.; Brisotti, J.L.; Oliveira, A.F.; Sasso, K.D. Basics aspects of the ischemia reperfusion injury and of the ischemic preconditioning. Acta Cir. Bras. 2002, 17. [CrossRef]

67. Salaris, S.C.; Babbs, C.F.; Voorhees, W.D. Methylene blue as an inhibitor of superoxide generation by xanthine oxidase. A potential new drug for the attenuation of ischemia/reperfusion injury. Biochem. Pharmacol. 1991, 42, 499-506. [CrossRef] 
68. Stirpe, F.; Della Corte, E. The regulation of rat liver xanthine oxidase. Conversion in vitro of the enzyme activity from dehydrogenase (type D) to oxidase (type O). J. Boil. Chem. 1969, 244, 3855-3863.

69. Garcea, G.; Gescher, A.; Steward, W.; Dennison, A.; Berry, D. Oxidative stress in humans following the Pringle manoeuvre. Hepatobiliary Pancreat. Dis. Int. 2006, 5, 210-214.

70. Vollmar, B.; Glasz, J.; Leiderer, R.; Post, S.; Menger, M.D. Hepatic microcirculatory perfusion failure is a determinant of liver dysfunction in warm ischemia-reperfusion. Am. J. Pathol. 1994, 145, 1421-1431.

71. Hou, J.; Xia, Y.; Jiang, R.; Chen, D.; Xu, J.; Deng, L.; Huang, X.; Wang, X.; Sun, B. PTPRO plays a dual role in hepatic ischemia reperfusion injury through feedback activation of NF-kappaB. J. Hepatol. 2014, 60, 306-312. [CrossRef]

72. Li, J.D.; Peng, Y.; Peng, X.Y.; Li, Q.L.; Li, Q. Suppression of nuclear factor-kappaB activity in Kupffer cells protects rat liver graft from ischemia-reperfusion injury. Transplant. Proc. 2010, 42, 1582-1586. [CrossRef]

73. Braz, M.M.; Elias-Miró, M.; Jiménez-Castro, M.B.; Casillas-Ramírez, A.; Ramalho, F.S.; Peralta, C. The Current State of Knowledge of Hepatic Ischemia-Reperfusion Injury Based on Its Study in Experimental Models. J. Biomed. Biotechnol. 2012, 2012, 1-20. [CrossRef]

74. Marzi, I.; Rucker, M.; Walcher, F.; Takei, Y. Endothelin-1 is involved in hepatic sinusoidal vasoconstriction after ischemia and reperfusion. Transpl. Int. 1994, 7 (Suppl. 1), S503-S506. [CrossRef]

75. Pelsers, M.M.; Namiot, Z.; Kisielewski, W.; Namiot, A.; Januszkiewicz, M.; Hermens, W.T.; Glatz, J.F. Intestinal-type and liver-type fatty acid-binding protein in the intestine. Tissue distribution and clinical utility. Clin. Biochem. 2003, 36, 529-535. [CrossRef]

76. Van Nieuwenhoven, F. Release of Proteins from Isolated Neonatal Rat Cardiomyocytes Subjected to Simulated Ischemia or Metabolic Inhibition is Independent of Molecular Mass. J. Mol. Cell. Cardiol. 1996, 28, 1429-1434. [CrossRef] [PubMed]

77. Çakir, Ö.Ö.; Toker, A.; Ataseven, H.; Demir, A.; Polat, H. The Importance of Liver-Fatty Acid Binding Protein in Diagnosis of Liver Damage in Patients with Acute Hepatitis. J. Clin. Diagn. Res. 2017, 11, OC17-OC21. [PubMed]

78. He, N.; Jia, J.-J.; Li, J.-H.; Zhou, Y.-F.; Lin, B.-Y.; Peng, Y.-F.; Chen, J.-J.; Chen, T.-C.; Tong, R.-L.; Jiang, L.; et al. Remote ischemic perconditioning prevents liver transplantation-induced ischemia/reperfusion injury in rats: Role of ROS/RNS and eNOS. World J. Gastroenterol. 2017, 23, 830-841. [CrossRef]

79. Dufour, D.R.; Lott, J.A.; Nolte, F.S.; Gretch, D.R.; Koff, R.S.; Seeff, L.B. Diagnosis and monitoring of hepatic injury. I. Performance characteristics of laboratory tests. Clin. Chem. 2000, 46, 2027-2049. [PubMed]

80. Trull, A.K. The clinical validation of novel strategies for monitoring transplant recipients. Clin. Biochem. 2001, 34, 3-7. [CrossRef]

81. Monbaliu, D.; De Vries, B.; Crabbé, T.; Van Heurn, E.; Verwaest, C.; Roskams, T.; Fevery, J.; Pirenne, J.; Buurman, W. Liver fatty acid-binding protein: An early and sensitive plasma marker of hepatocellular damage and a reliable predictor of graft viability after liver transplantation from non-heart-beating donors. Transplant. Proc. 2005, 37, 413-416. [CrossRef]

82. Wang, G.; Bonkovsky, H.L.; De Lemos, A.; Burczynski, F.J. Recent insights into the biological functions of liver fatty acid binding protein 1. J. Lipid Res. 2015, 56, 2238-2247. [CrossRef] [PubMed]

83. Davis, C.L.; Gonwa, T.A.; Wilkinson, A.H. Pathophysiology of renal disease associated with liver disorders: Implications for liver transplantation. Part I. Liver Transplant. 2002, 8, 91-109. [CrossRef] [PubMed]

84. Tanaka, Y.; Maher, J.M.; Chen, C.; Klaassen, C.D. Hepatic ischemia-reperfusion induces renal heme oxygenase-1 via NF-E2-related factor 2 in rats and mice. Mol. Pharmacol. 2007, 71, 817-825. [CrossRef] [PubMed]

85. Sutton, T.A.; Mang, H.E.; Campos, S.B.; Sandoval, R.M.; Yoder, M.C.; Molitoris, B.A. Injury of the renal microvascular endothelium alters barrier function after ischemia. Am. J. Physiol. Physiol. 2003, 285, F191-F198. [CrossRef]

86. Molitoris, B.A. Actin cytoskeleton in ischemic acute renal failure. Kidney Int. 2004, 66, 871-883. [CrossRef] [PubMed]

87. Lee, H.T.; Park, S.W.; Kim, M.; D'Agati, V.D. Acute kidney injury after hepatic ischemia and reperfusion injury in mice. Lab. Investig. 2009, 89, 196-208. [CrossRef] [PubMed]

88. Kadkhodaee, M.; Mikaeili, S.; Zahmatkesh, M.; Golab, F.; Seifi, B.; Arab, H.-A.; Shams, S.; Mahdavi-Mazdeh, M. Alteration of renal functional, oxidative stress and inflammatory indices following hepatic ischemia-reperfusion. Gen. Physiol. Biophys. 2012, 31, 195-202. [CrossRef] 
89. Polat, C.; Tokyol, C.; Kahraman, A.; Sabuncuoğlu, B.; Yilmaz, S. The effects of desferrioxamine and quercetin on hepatic ischemia-reperfusion induced renal disturbance. Prostaglandins Leukot. Essent. Fat. Acids 2006, 74, 379-383. [CrossRef]

90. Park, S.W.; Chen, S.W.; Kim, M.; D'Agati, V.D.; Lee, H.T. Human activated protein C attenuates both hepatic and renal injury caused by hepatic ischemia and reperfusion injury in mice. Kidney Int. 2009, 76, 739-750. [CrossRef]

91. Suzuki, S.; Serizawa, A.; Sakaguchi, T.; Tsuchiya, Y.; Kojima, Y.; Okamoto, K.; Kurachi, K.; Konno, H.; Fujise, Y.; Baba, S.; et al. The roles of platelet-activating factor and endothelin-1 in renal damage after total hepatic ischemia and reperfusion. Transplantation 2000, 69, 2267-2273. [CrossRef]

92. Tucker, D.; Lu, Y.; Zhang, Q. From Mitochondrial Function to Neuroprotection-an Emerging Role for Methylene Blue. Mol. Neurobiol. 2018, 55, 5137-5153. [CrossRef] [PubMed]

93. Dziedzic, T. Systemic inflammation as a therapeutic target in acute ischemic stroke. Expert Rev. Neurother. 2015, 15, 523-531. [CrossRef] [PubMed]

94. Jin, R.; Liu, L.; Zhang, S.; Nanda, A.; Li, G. Role of inflammation and its mediators in acute ischemic stroke. J. Cardiovasc. Transl. Res. 2013, 6, 834-851. [CrossRef] [PubMed]

95. Licata, G.; Tuttolomondo, A.; Corrao, S.; Di Raimondo, D.; Fernandez, P.; Caruso, C.; Avellone, G.; Pinto, A. Immunoinflammatory Activation during the Acute Phase of Lacunar and Non-Lacunar Ischemic Stroke: Association with Time of Onset and Diabetic State. Int. J. Immunopathol. Pharmacol. 2006, 19, 639-646. [CrossRef] [PubMed]

96. Schauer, R.J.; Kalmuk, S.; Gerbes, A.L.; Leiderer, R.; Meissner, H.; Schildberg, F.W.; Messmer, K.; Bilzer, M. Intravenous administration of glutathione protects parenchymal and non-parenchymal liver cells against reperfusion injury following rat liver transplantation. World J. Gastroenterol. 2004, 10, 864-870. [CrossRef] [PubMed]

97. Zhou, H.; Ma, Q.; Zhu, P.; Ren, J.; Reiter, R.J.; Chen, Y. Protective role of melatonin in cardiac ischemiareperfusion injury: From pathogenesis to targeted therapy. J. Pineal Res. 2018, 64, e12471. [CrossRef] [PubMed]

98. Kerksick, C.; Willoughby, D. The Antioxidant Role of Glutathione and N-Acetyl-Cysteine Supplements and Exercise-Induced Oxidative Stress. J. Int. Soc. Sports Nutr. 2005, 2, 38-44. [CrossRef] [PubMed]

99. Kantor, P.F.; Lucien, A.; Kozak, R.; Lopaschuk, G.D. The Antianginal Drug Trimetazidine Shifts Cardiac Energy Metabolism from Fatty Acid Oxidation to Glucose Oxidation by Inhibiting Mitochondrial Long-Chain 3-Ketoacyl Coenzyme a Thiolase. Circ. Res. 2000, 86, 580-588. [CrossRef] [PubMed]

100. Lopaschuk, G.D. Metabolic Modulators in Heart Disease: Past, Present, and Future. Can. J. Cardiol. 2017, 33, 838-849. [CrossRef] [PubMed]

101. Liu, Z.; Chen, J.M.; Huang, H.; Kuznicki, M.; Zheng, S.; Sun, W.; Quan, N.; Wang, L.; Yang, H.; Guo, H.M.; et al. The protective effect of trimetazidine on myocardial ischemia/reperfusion injury through activating AMPK and ERK signaling pathway. Metabolism 2016, 65, 122-130. [CrossRef] [PubMed]

102. Rossello, X.; Yellon, D.M. The RISK pathway and beyond. Basic Res. Cardiol. 2018, 113, 2. [CrossRef] [PubMed]

103. Eltzschig, H.K.; Eckle, T. Ischemia and reperfusion-from mechanism to translation. Nat. Med. 2011, 17, $1391-1401$. [CrossRef] [PubMed]

104. Burley, D.S.; Ferdinandy, P.; Baxter, G.F. Cyclic GMP and protein kinase-G in myocardial ischaemia-reperfusion: Opportunities and obstacles for survival signaling. Br. J. Pharmacol. 2007, 152, 855-869. [CrossRef] [PubMed]

105. Cadenas, S. ROS and redox signaling in myocardial ischemia-reperfusion injury and cardioprotection. Free Radic. Boil. Med. 2018, 117, 76-89. [CrossRef] [PubMed]

106. Jiang, S.; Li, T.; Ji, T.; Yi, W.; Yang, Z.; Wang, S.; Yang, Y.; Gu, C. AMPK: Potential Therapeutic Target for Ischemic Stroke. Theranostics 2018, 8, 4535-4551. [CrossRef] [PubMed]

107. Wu, M.-Y.; Yiang, G.-T.; Liao, W.-T.; Tsai, A.P.-Y.; Cheng, Y.-L.; Cheng, P.-W.; Li, C.-Y.; Li, C.-J. Current Mechanistic Concepts in Ischemia and Reperfusion Injury. Cell. Physiol. Biochem. 2018, 46, 1650-1667. [CrossRef] [PubMed]

108. Hausenloy, D.J.; Lecour, S.; Yellon, D.M. Reperfusion Injury Salvage Kinase and Survivor Activating Factor Enhancement Prosurvival Signaling Pathways in Ischemic Postconditioning: Two Sides of the Same Coin. Antioxid. Redox Signal. 2011, 14, 893-907. [CrossRef] 
109. Yellon, D.M.; Hausenloy, D.J. New directions for protecting the heart against ischaemia-reperfusion injury: Targeting the Reperfusion Injury Salvage Kinase (RISK)-pathway. Cardiovasc. Res. 2004, 61, 448-460.

110. Ghaboura, N.; Tamareille, S.; Ducluzeau, P.H.; Grimaud, L.; Loufrani, L.; Croue, A.; Tourmen, Y.; Henrion, D.; Furber, A.; Prunier, F. Diabetes mellitus abrogates erythropoietin-induced cardioprotection against ischemic-reperfusion injury by alteration of the RISK/GSK-3beta signaling. Basic Res. Cardiol. 2011, 106, 147-162. [CrossRef]

111. Schulman, D.; Latchman, D.S.; Yellon, D.M. Urocortin protects the heart from reperfusion injury via upregulation of p42/p44 MAPK signaling pathway. Am. J. Physiol. Circ. Physiol. 2002, 283, H1481-H1488. [CrossRef]

112. Yellon, D.M.; Hausenloy, D.J. Mechanisms of disease: Myocardial reperfusion injury. N. Engl. J. Med. 2007, 357, 1121-1135. [CrossRef]

113. Murphy, E.; Steenbergen, C. Mechanisms underlying acute protection from cardiac ischemia-reperfusion injury. Physiol. Rev. 2008, 88, 581-609. [CrossRef] [PubMed]

114. Walters, A.M.; Porter, G.A., Jr.; Brookes, P.S. Mitochondria as a drug target in ischemic heart disease and cardiomyopathy. Circ. Res. 2012, 111, 1222-1236. [CrossRef] [PubMed]

115. Zhang, Y.; Lv, F.; Jin, L.; Peng, W.; Song, R.; Ma, J.; Cao, C.-M.; Xiao, R.-P. MG53 participates in ischaemic postconditioning through the RISK signalling pathway. Cardiovasc. Res. 2011, 91, 108-115. [CrossRef] [PubMed]

116. Hausenloy, D.J.; Yellon, D.M. Reperfusion injury salvage kinase signalling: Taking a RISK for cardioprotection. Heart Fail. Rev. 2007, 12, 217-234. [CrossRef] [PubMed]

117. Lecour, S. Activation of the protective Survivor Activating Factor Enhancement (SAFE) pathway against reperfusion injury: Does it go beyond the RISK pathway? J. Mol. Cell. Cardiol. 2009, 47, 32-40. [CrossRef] [PubMed]

118. Tartaglia, L.A.; Weber, R.F.; Figari, I.S.; Reynolds, C.; Palladino, M.A.; Goeddel, D.V. The two different receptors for tumor necrosis factor mediate distinct cellular responses. Proc. Natl. Acad. Sci. USA 1991, 88, 9292-9296. [CrossRef] [PubMed]

119. Lecour, S.; James, R.W. When are pro-inflammatory cytokines SAFE in heart failure? Eur. Heart J. 2011, 32, 680-685. [CrossRef] [PubMed]

120. Amit-Vazina, M.; Shishodia, S.; Harris, D.; Van, Q.; Wang, M.; Weber, D.; Alexanian, R.; Talpaz, M.; Aggarwal, B.B.; Estrov, Z. Atiprimod blocks STAT3 phosphorylation and induces apoptosis in multiple myeloma cells. Br. J. Cancer 2005, 93, 70-80. [CrossRef]

121. Liu, H.; Huang, Q.; Shi, B.; Eksarko, P.; Temkin, V.; Pope, R.M. Regulation of Mcl-1 expression in rheumatoid arthritis synovial macrophages. Arthritis Rheum. 2006, 54, 3174-3181. [CrossRef]

122. Zhang, X.; Zhang, J.; Wei, H.; Tian, Z. STAT3-decoy oligodeoxynucleotide inhibits the growth of human lung cancer via down-regulating its target genes. Oncol. Rep. 2007, 17, 1377-1382. [CrossRef] [PubMed]

123. Torbenson, M.; Yang, S.Q.; Liu, H.Z.; Huang, J.; Gage, W.; Diehl, A.M. STAT-3 Overexpression and p21 Up-Regulation Accompany Impaired Regeneration of Fatty Livers. Am. J. Pathol. 2002, 161, 155-161. [CrossRef]

124. Ikezoe, T.; Saito, T.; Bandobashi, K.; Yang, Y.; Koeffler, H.P.; Taguchi, H. HIV-1 protease inhibitor induces growth arrest and apoptosis of human multiple myeloma cells via inactivation of signal transducer and activator of transcription 3 and extracellular signal-regulated kinase 1/2. Mol. Cancer Ther. 2004, 3, 473-479. [PubMed]

125. Marqués, J.M.; Belza, I.; Holtmann, B.; Pennica, D.; Prieto, J.; Bustos, M. Cardiotrophin-1 is an essential factor in the natural defense of the liver against apoptosis. Hepatology 2007, 45, 639-648. [CrossRef] [PubMed]

126. Pavo, N.; Lukovic, D.; Zlabinger, K.; Zimba, A.; Lorant, D.; Goliasch, G.; Winkler, J.; Pils, D.; Auer, K.; Ankersmit, H.J.; et al. Sequential activation of different pathway networks in ischemia-affected and non-affected myocardium, inducing intrinsic remote conditioning to prevent left ventricular remodeling. Sci. Rep. 2017, 7, 43958. [CrossRef] [PubMed]

127. Feyzizadeh, S.; Badalzadeh, R. Application of ischemic postconditioning's algorithms in tissues protection: Response to methodological gaps in preclinical and clinical studies. J. Cell. Mol. Med. 2017, 21, 2257-2267. [CrossRef] [PubMed] 
128. Xin, W.K.; Yang, X.L.; Rich, T.C.; Krieg, T.; Barrington, R.; Cohen, M.V.; Downey, J.M. All PreconditioningRelated G Protein-Coupled Receptors Can Be Demonstrated in the Rabbit Cardiomyocyte. J. Cardiovasc. Pharmacol. Ther. 2012, 17, 190-198. [CrossRef] [PubMed]

129. Costa, M.A.; Elesgaray, R.; Balaszczuk, A.M.; Arranz, C. Role of NPR-C natriuretic receptor in nitric oxide system activation induced by atrial natriuretic peptide. Regul. Pept. 2006, 135, 63-68. [CrossRef] [PubMed]

130. Shiva, S.; Sack, M.N.; Greer, J.J.; Duranski, M.; Ringwood, L.A.; Burwell, L.; Wang, X.; MacArthur, P.H.; Shoja, A.; Raghavachari, N.; et al. Nitrite augments tolerance to ischemia/reperfusion injury via the modulation of mitochondrial electron transfer. J. Exp. Med. 2007, 204, 2089-2102. [CrossRef] [PubMed]

131. Duranski, M.R.; Greer, J.J.; Dejam, A.; Jaganmohan, S.; Hogg, N.; Langston, W.; Patel, R.P.; Yet, S.-F.; Wang, X.; Kevil, C.G.; et al. Cytoprotective effects of nitrite during in vivo ischemia-reperfusion of the heart and liver. J. Clin. Investig. 2005, 115, 1232-1240. [CrossRef] [PubMed]

132. Cohen, M.V.; Yang, X.-M.; Liu, Y.; Solenkova, N.V.; Downey, J.M. Cardioprotective PKG-independent NO signaling at reperfusion. Am. J. Physiol. Circ. Physiol. 2010, 299, H2028-H2036. [CrossRef] [PubMed]

133. Inserte, J.; Garcia-Dorado, D. The cGMP/PKG pathway as a common mediator of cardioprotection: Translatability and mechanism. Br. J. Pharmacol. 2015, 172, 1996-2009. [CrossRef] [PubMed]

134. Lin, H.-B.; Cadete, V.J.; Sawicka, J.; Wozniak, M.; Sawicki, G. Effect of the myosin light chain kinase inhibitor ML-7 on the proteome of hearts subjected to ischemia-reperfusion injury. J. Proteom. 2012, 75, 5386-5395. [CrossRef] [PubMed]

135. Zhang, Y.S.; Liu, B.; Luo, X.J.; Zhang, J.J.; Li, N.S.; Ma, Q.L.; Jiang, J.L.; Li, Y.J.; Li, Q.; Peng, J. A novel function of nuclear nonmuscle myosin regulatory light chain in promotion of xanthine oxidase transcription after myocardial ischemia/reperfusion. Free Radic. Biol. Med. 2015, 83, 115-128. [CrossRef] [PubMed]

136. Evora, P.R.; Alves Junior, L.; Ferreira, C.A.; Menardi, A.C.; Bassetto, S.; Rodrigues, A.J.; Scorzoni Filho, A.; Vicente, W.V. Twenty years of vasoplegic syndrome treatment in heart surgery. Methylene blue revised. Rev. Bras. Cir. Cardiovasc. 2015, 30, 84-92. [CrossRef] [PubMed]

137. Rodrigues, J.M.; Filho, A.P.; Rodrigues, A.J.; Vicente, W.V.D.A.; Evora, P.R.B. Methylene blue for clinical anaphylaxis treatment: A case report. Sao Paulo Med. J. 2007, 125, 60-62. [CrossRef] [PubMed]

138. Rosique, R.G.; Rosique, M.; Rosique, I.; Tirapelli, L.; Silva, O.C.E.; Dos Santos, J.; Evora, P. Effect of Methylene Blue on the Hemodynamic Instability Resulting from Liver Ischemia and Reperfusion in Rabbits. Transplant. Proc. 2011, 43, 3643-3651. [CrossRef]

139. Tian, W.F.; Zeng, S.; Sheng, Q.; Chen, J.L.; Weng, P.; Zhang, X.T.; Yuan, J.J.; Pang, Q.F.; Wang, Z.Q. Methylene Blue Protects the Isolated Rat Lungs from Ischemia-Reperfusion Injury by Attenuating Mitochondrial Oxidative Damage. Lung 2018, 196, 73-82. [CrossRef]

140. Wang, L.; Chen, B.; Lin, B.; Ye, Y.; Bao, C.; Zhao, X.; Jin, L.; Xiong, X. Methylene Blue Attenuates Lung Injury Induced by Hindlimb Ischemia Reperfusion in Rats. Mediat. Inflamm. 2018, 2018, 1-8. [CrossRef]

141. Sarac, F.; Kilincaslan, H.; Kilic, E.; Koldaş, M.; Terzi, E.H.; Aydogdu, I.; Kılıncaslan, H.; K1lıc, E. Methylene blue attenuates renal ischemia-reperfusion injury in rats. J. Pediatr. Surg. 2015, 50, 1067-1071. [CrossRef]

142. Liu, P.-G.; He, S.-Q.; Zhang, Y.-H.; Wu, J. Protective effects of apocynin and allopurinol on ischemia/reperfusion-induced liver injury in mice. World J. Gastroenterol. 2008, 14, 2832-2837. [CrossRef] [PubMed]

143. Zhou, J.-Q.; Qiu, T.; Zhang, L.; Chen, Z.-B.; Wang, Z.-S.; Ma, X.-X.; Li, D. Allopurinol preconditioning attenuates renal ischemia/reperfusion injury by inhibiting HMGB1 expression in a rat model. Acta Cir. Bras. 2016, 31, 176-182. [CrossRef] [PubMed]

144. Jeong, J.; Kim, D.; Kim, K.; Ryu, S.; Han, S.; Shin, B.; Kim, G.; Gwak, M.; Ko, J. Ischemic Preconditioning Produces Comparable Protection Against Hepatic Ischemia/Reperfusion Injury Under Isoflurane and Sevoflurane Anesthesia in Rats. Transplant. Proc. 2017, 49, 2188-2193. [CrossRef] [PubMed]

145. Abu-Amara, M.; Gurusamy, K.; Hori, S.; Glantzounis, G.; Fuller, B.; Davidson, B.R. Systematic review of randomized controlled trials of pharmacological interventions to reduce ischaemia-reperfusion injury in elective liver resection with vascular occlusion. HPB 2010, 12, 4-14. [CrossRef] [PubMed]

146. Li, X.; Su, L.; Zhang, X.; Zhang, C.; Wang, L.; Li, Y.; Zhang, Y.; He, T.; Zhu, X.; Cui, L. Ulinastatin downregulates TLR4 and NF-kB expression and protects mouse brains against ischemia/reperfusion injury. Neurol. Res. 2017, 39, 1-7. [CrossRef] [PubMed]

147. Li, W.; Li, P.; Li, Z.; Liu, H.; Guan, L.; Zhang, L. Effects of Ulinastatin on Liver Warm Ischemia Reperfusion Injury in Mice. Transplantation 2018, 102, S705. [CrossRef] 
148. Xu, Z.; Yu, J.; Wu, J.; Qi, F.; Wang, H.; Wang, Z.; Wang, Z. The Effects of Two Anesthetics, Propofol and Sevoflurane, on Liver Ischemia/Reperfusion Injury. Cell. Physiol. Biochem. 2016, 38, 1631-1642. [CrossRef]

149. Yang, S.; Chou, W.-P.; Pei, L. Effects of propofol on renal ischemia/reperfusion injury in rats. Exp. Ther. Med. 2013, 6, 1177-1183. [CrossRef]

150. Malek, M.; Nematbakhsh, M. Renal ischemia/reperfusion injury; from pathophysiology to treatment. J. Ren. Inj. Prev. 2015, 4, 20-27.

151. Li, P.D.; Fu, P.Y.; Li, Z.N.; Ye, Y.S.; Wang, Z.P.; Liu, H.Y.; Li, W.; Guan, L.Y. Effects of Ulinastatin on liver warm ischemia reperfusion injury in mice. Transplantation 2016, 100, S705. [CrossRef]

152. Katayama, Y.; Inaba, T.; Nito, C.; Ueda, M.; Katsura, K. Neuroprotective effects of erythromycin on cerebral ischemia reperfusion-injury and cell viability after oxygen-glucose deprivation in cultured neuronal cells. Brain Res. 2014, 1588, 159-167. [CrossRef] [PubMed]

153. Soliman, S.; Ishrat, T.; Fouda, A.Y.; Patel, A.; Pillai, B.; Fagan, S.C. Sequential Therapy with Minocycline and Candesartan Improves Long-Term Recovery After Experimental Stroke. Transl. Stroke Res. 2015, 6, 309-322. [CrossRef] [PubMed]

154. Kozak, A.; Ergul, A.; El-Remessy, A.B.; Johnson, M.H.; Machado, L.S.; Elewa, H.F.; Abdelsaid, M.; Wiley, D.C.; Fagan, S.C. Candesartan augments ischemia-induced proangiogenic state and results in sustained improvement after stroke. Stroke 2009, 40, 1870-1876. [CrossRef] [PubMed]

155. Price, N.L.; Gomes, A.P.; Ling, A.J.; Duarte, F.V.; Martin-Montalvo, A.; North, B.J.; Agarwal, B.; Ye, L.; Ramadori, G.; Teodoro, J.S.; et al. SIRT1 is required for AMPK activation and the beneficial effects of resveratrol on mitochondrial function. Cell Metab. 2012, 15, 675-690. [CrossRef] [PubMed]

156. Athar, M.; Back, J.H.; Kopelovich, L.; Bickers, D.R.; Kim, A.L. Multiple molecular Targets of Resveratrol: Anti-carcinogenic Mechanisms. Arch. Biochem. Biophys. 2009, 486, 95-102. [CrossRef] [PubMed]

157. De Oliveira, M.R.; Nabavi, S.F.; Manayi, A.; Daglia, M.; Hajheydari, Z.; Nabavi, S.M. Resveratrol and the mitochondria: From triggering the intrinsic apoptotic pathway to inducing mitochondrial biogenesis, a mechanistic view. Biochim. Biophys. Acta BBA Gen. Subj. 2016, 1860, 727-745. [CrossRef] [PubMed]

158. Kulkarni, S.S.; Cantó, C. The molecular targets of resveratrol. Biochim. Biophys. Acta BBA Mol. Basis Dis. 2015, 1852, 1114-1123. [CrossRef] [PubMed]

159. Sweitzer, N.K.; Airhart, S. New Therapeutic Target in Heart Failure: Achieving and Maintaining Normokalemia. Circulation 2018, 137, 1331-1333. [CrossRef] [PubMed]

160. Cannavo, A.; Komici, K.; Bencivenga, L.; D'Amico, M.L.; Gambino, G.; Liccardo, D.; Ferrara, N.; Rengo, G. GRK2 as a therapeutic target for heart failure. Expert Opin. Ther. Targets 2018, 22, 75-83. [CrossRef] [PubMed]

161. Wang, Q.; Lin, P.; Li, P.; Feng, L.; Ren, Q.; Xie, X.; Xu, J. Ghrelin protects the heart against ischemia/reperfusion injury via inhibition of TLR4/NLRP3 inflammasome pathway. Life Sci. 2017, 186, 50-58. [CrossRef]

162. Bakker, P.J.; Butter, L.M.; Claessen, N.; Teske, G.J.; Sutterwala, F.S.; Florquin, S.; Leemans, J.C. A tissue-specific role for Nlrp3 in tubular epithelial repair after renal ischemia/reperfusion. Am. J. Pathol. 2014, 184, 2013-2022. [CrossRef] [PubMed]

163. Kojima, M.; Kangawa, K. Drug Insight: The functions of ghrelin and its potential as a multitherapeutic hormone. Nat. Clin. Pract. Endocrinol. Metab. 2006, 2, 80-88. [CrossRef] [PubMed]

164. Soeki, T.; Kishimoto, I.; Schwenke, D.O.; Tokudome, T.; Horio, T.; Yoshida, M.; Hosoda, H.; Kangawa, K. Ghrelin suppresses cardiac sympathetic activity and prevents early left ventricular remodeling in rats with myocardial infarction. Am. J. Physiol. Circ. Physiol. 2008, 294, H426-H432. [CrossRef] [PubMed]

165. Budas, G.R.; Disatnik, M.-H.; Mochly-Rosen, D. Aldehyde dehydrogenase 2 in cardiac protection: A new therapeutic target? Trends Cardiovasc. Med. 2009, 19, 158-164. [CrossRef] [PubMed]

166. Chen, C.-H.; Budas, G.R.; Churchill, E.N.; Disatnik, M.-H.; Hurley, T.D.; Mochly-Rosen, D. Activation of aldehyde dehydrogenase-2 reduces ischemic damage to the heart. Science 2008, 321, 1493-1495. [CrossRef] [PubMed]

167. Doser, T.A.; Turdi, S.; Thomas, D.P.; Epstein, P.N.; Li, S.-Y.; Ren, J. Transgenic overexpression of aldehyde dehydrogenase-2 rescues chronic alcohol intake-induced myocardial hypertrophy and contractile dysfunction. Circulation 2009, 119, 1941-1949. [CrossRef]

168. Ma, H.; Guo, R.; Yu, L.; Zhang, Y.; Ren, J. Aldehyde dehydrogenase 2 (ALDH2) rescues myocardial ischaemia/ reperfusion injury: Role of autophagy paradox and toxic aldehyde. Eur. Heart J. 2011, 32, 1025-1038. [CrossRef] 
169. Panisello-Roselló, A.; Lopez, A.; Folch-Puy, E.; Carbonell, T.; Rolo, A.; Palmeira, C.; Adam, R.; Net, M.; Roselló-Catafau, J. Role of aldehyde dehydrogenase 2 in ischemia reperfusion injury: An update. World J. Gastroenterol. 2018, 24, 2984-2994. [CrossRef]

170. Panisello-Rosello, A.; Alva, N.; Flores, M.; Lopez, A.; Castro Benitez, C.; Folch-Puy, E.; Rolo, A.; Palmeira, C.; Adam, R.; Carbonell, T.; et al. Aldehyde Dehydrogenase 2 (ALDH2) in Rat Fatty Liver Cold Ischemia Injury. Int. J. Mol. Sci. 2018, 19, 2479. [CrossRef]

171. Shimizu, M.; Wang, Q.-D.; Sjöquist, P.-O.; Rydén, L. Angiotensin II Type 1 Receptor Blockade with Candesartan Protects the Porcine Myocardium from Reperfusion-Induced Injury. J. Cardiovasc. Pharmacol. 1998, 32, 231-238. [CrossRef]

172. Venkat, P.; Shen, Y.; Chopp, M.; Chen, J. Cell-based and pharmacological neurorestorative therapies for ischemic stroke. Neuropharmacology 2018, 134, 310-322. [CrossRef] [PubMed]

173. Zhou, H.; Zhang, Y.; Hu, S.; Shi, C.; Zhu, P.; Ma, Q.; Jin, Q.; Cao, F.; Tian, F.; Chen, Y. Melatonin protects cardiac microvasculature against ischemia/reperfusion injury via suppression of mitochondrial fission-VDAC1-HK2-mPTP-mitophagy axis. J. Pineal Res. 2017, 63, e12413. [CrossRef] [PubMed]

174. Zhai, M.; Li, B.; Duan, W.; Jing, L.; Zhang, B.; Zhang, M.; Yu, L.; Liu, Z.; Yu, B.; Ren, K.; et al. Melatonin ameliorates myocardial ischemia reperfusion injury through SIRT3-dependent regulation of oxidative stress and apoptosis. J. Pineal Res. 2017, 63, e12419. [CrossRef] [PubMed]

175. Zhou, H.; Li, D.; Zhu, P.; Hu, S.; Hu, N.; Ma, S.; Zhang, Y.; Han, T.; Ren, J.; Cao, F.; et al. Melatonin suppresses platelet activation and function against cardiac ischemia/reperfusion injury via PPARgamma/ FUNDC1/mitophagy pathways. J. Pineal Res. 2017, 63. [CrossRef] [PubMed]

176. He, B.; Zhao, Y.; Xu, L.; Gao, L.; Su, Y.; Lin, N.; Pu, J. The nuclear melatonin receptor ROR $\alpha$ is a novel endogenous defender against myocardial ischemia/reperfusion injury. J. Pineal Res. 2016, 60, 313-326. [CrossRef] [PubMed]

177. Yu, L.M.; Gong, B.; Duan, W.X.; Fan, C.X.; Zhang, J.; Li, Z.; Xue, X.D.; Xu, Y.L.; Meng, D.D.; Li, B.Y.; et al. Melatonin ameliorates myocardial ischemia/reperfusion injury in type 1 diabetic rats by preserving mitochondrial function: Role of AMPK-PGC-1 alpha-SIRT3 signaling. Sci. Rep. 2017, 7, 41337. [CrossRef] [PubMed]

178. Ito, K.; Ozasa, H.; Horikawa, S. Edaravone protects against lung injury induced by intestinal ischemia/reperfusion in rat. Free Radic. Boil. Med. 2005, 38, 369-374. [CrossRef] [PubMed]

179. Taylor, J.M.; Flentjar, N.J.; De Haan, J.; Hertzog, P.; Kola, I.; Crack, P.J.; Iannello, R.C. Increased infarct size and exacerbated apoptosis in the glutathione peroxidase-1 (Gpx-1) knockout mouse brain in response to ischemia/reperfusion injury. J. Neurochem. 2001, 78, 1389-1399.

180. Suyavaran, A.; Ramamurthy, C.; Mareeswaran, R.; Subastri, A.; Lokeswara Rao, P.; Thirunavukkarasu, C. TNF-alpha suppression by glutathione preconditioning attenuates hepatic ischemia reperfusion injury in young and aged rats. Inflamm. Res. 2015, 64, 71-81. [CrossRef]

181. Whillier, S.; Raftos, J.E.; Chapman, B.; Kuchel, P.W. Role ofN-acetylcysteine and cystine in glutathione synthesis in human erythrocytes. Redox Rep. 2009, 14, 115-124. [CrossRef]

182. Kalimeris, K.; Briassoulis, P.; Ntzouvani, A.; Nomikos, T.; Papaparaskeva, K.; Politi, A.; Batistaki, C.; Kostopanagiotou, G. N-acetylcysteine ameliorates liver injury in a rat model of intestinal ischemia reperfusion. J. Surg. Res. 2016, 206, 263-272. [CrossRef]

183. Kim, H.Y.; Kim, S.J.; Lee, S.M. Activation of NLRP3 and AIM2 inflammasomes in Kupffer cells in hepatic ischemia/reperfusion. FEBS J. 2015, 282, 259-270. [CrossRef] [PubMed]

184. Weigand, M.A.; Plachky, J.; Thies, J.C.; Spies-Martin, D.; Otto, G.; Martin, E.; Bardenheuer, H.J. $\mathrm{N}$-acetylcysteine attenuates the increase in alpha-glutathione S-transferase and circulating ICAM-1 and VCAM-1 after reperfusion in humans undergoing liver transplantation. Transplantation 2001, 72, 694-698. [CrossRef] [PubMed]

185. Karlsson, J.O.G.; Ignarro, L.J.; Lundström, I.; Jynge, P.; Almén, T. Calmangafodipir $\left[\mathrm{Ca}_{4} \mathrm{Mn}(\mathrm{DPDP})_{5}\right]$, mangafodipir (MnDPDP) and MnPLED with special reference to their SOD mimetic and therapeutic properties. Drug Discov. Today 2015, 20, 411-421. [CrossRef] [PubMed]

186. Ben Mosbah, I.; Mouchel, Y.; Pajaud, J.; Ribault, C.; Lucas, C.; Laurent, A.; Boudjema, K.; Morel, F.; Corlu, A.; Compagnon, P. Pretreatment with Mangafodipir Improves Liver Graft Tolerance to Ischemia/Reperfusion Injury in Rat. PLoS ONE 2012, 7, e50235. [CrossRef] [PubMed] 
187. El-Saadi, W.; Puskar, W.; Skogvard, P.; Engvall, J.E.; Andersson, R.G.; Karlsson, J.-E.; Ali, M.; Maret, E.; Jynge, P. Mangafodipir as a cardioprotective adjunct to reperfusion therapy: A feasibility study in patients with ST-segment elevation myocardial infarction. Eur. Hear. J. Cardiovasc. Pharmacother. 2015, 1, $39-45$.

188. Beckman, J.S.; Koppenol, W.H. Nitric oxide, superoxide, and peroxynitrite: The good, the bad, and the ugly. Am. J. Physiol. Cell Physiol. 1996, 271, C1424-C1437. [CrossRef]

189. Marcelino, P.; Marinho, H.S.; Campos, M.C.; Neves, A.R.; Real, C.; Fontes, F.S.; Carvalho, A.; Feio, G.; Martins, M.B.F.; Corvo, M.L. Therapeutic activity of superoxide dismutase-containing enzymosomes on rat liver ischaemia-reperfusion injury followed by magnetic resonance microscopy. Eur. J. Pharm. Sci. 2017, 109, 464-471. [CrossRef]

190. Carillon, J.; Rouanet, J.-M.; Cristol, J.-P.; Brion, R. Superoxide Dismutase Administration, a Potential Therapy Against Oxidative Stress Related Diseases: Several Routes of Supplementation and Proposal of an Original Mechanism of Action. Pharm. Res. 2013, 30, 2718-2728. [CrossRef]

191. Chen, C.; Lu, W.; Wu, G.; Lv, L.; Chen, W.; Huang, L.; Wu, X.; Xu, N.; Wu, Y. Cardioprotective effects of combined therapy with diltiazem and superoxide dismutase on myocardial ischemia-reperfusion injury in rats. Life Sci. 2017, 183, 50-59. [CrossRef]

192. Pinto, A.; Immohr, M.B.; Jahn, A.; Jenke, A.; Boeken, U.; Lichtenberg, A.; Akhyari, P. The extracellular isoform of superoxide dismutase has a significant impact on cardiovascular ischaemia and reperfusion injury during cardiopulmonary bypass. Eur. J. Cardio-Thorac. Surg. 2016, 50, 1035-1044. [CrossRef]

193. Wieland, E.; Schütz, E.; Armstrong, V.W.; Küthe, F.; Heller, C.; Oellerich, M. Idebenone protects hepatic microsomes against oxygen radical-mediated damage in organ preservation solutions. Transplantation 1995, 60, 444-450. [CrossRef] [PubMed]

194. Yuan, H.P.; Lei, D.W.; Shao, Z.B.; Zhou, X.R. Synergistic neuroprotective effect of rasagiline and idebenone against retinal ischemia-reperfusion injury via the Lin28-let-7-Dicer pathway. Oncotarget 2018, 9, 12137-12153.

195. Obici, S.; Feng, Z.; Arduini, A.; Conti, R.; Rossetti, L. Inhibition of hypothalamic carnitine palmitoyltransferase-1 decreases food intake and glucose production. Nat. Med. 2003, 9, 756-761. [CrossRef] [PubMed]

196. Bremer, J. The Effect of Fasting on the Activity of Liver Carnitine Palmitoyltransferase and Its Inhibition by Malonyl-Coa. Biochim. Biophys. Acta 1981, 665, 628-631. [CrossRef]

197. Chavez, P.N.; Stanley, W.C.; McElfresh, T.A.; Huang, H.; Sterk, J.P.; Chandler, M.P. Effect of hyperglycemia and fatty acid oxidation inhibition during aerobic conditions and demand-induced ischemia. Am. J. Physiol. Circ. Physiol. 2003, 284, H1521-H1527. [CrossRef]

198. Linke, A.; Chandler, M.P.; Young, M.E.; Penn, M.S.; Gupte, S.; D'Agostino, C.; Hintze, T.H.; Lionetti, V.; Stanley, W.C.; Recchia, F.A. Carnitine palmitoyl transferase-I inhibition prevents ventricular remodeling and delays decompensation in pacing-induced heart failure. Cardiovasc. Res. 2005, 66, 454-461.

199. Chang, K.-C.; Liang, J.-T.; Wu, M.-S.; Chang, K.-C.; Tseng, C.-D.; Lu, S.-C.; Liang, J.-T.; Wu, M.-S.; Tsai, M.-S.; Hsu, K.-L.; et al. Effects of acetyl-L-carnitine and oxfenicine on aorta stiffness in diabetic rats. Eur. J. Clin. Investig. 2010, 40, 1002-1010. [CrossRef] [PubMed]

200. Maarman, G.; Marais, E.; Lochner, A.; Du Toit, E.F.; Toit, E.F. Effect of Chronic CPT-1 Inhibition on Myocardial Ischemia-Reperfusion Injury (I/R) in a Model of Diet-Induced Obesity. Cardiovasc. Drugs Ther. 2012, 26, 205-216. [CrossRef] [PubMed]

201. Lopaschuk, G.D.; Wall, S.R.; Olley, P.M.; Davies, N.J. Etomoxir, a carnitine palmitoyltransferase I inhibitor, protects hearts from fatty acid-induced ischemic injury independent of changes in long chain acylcarnitine. Circ. Res. 1988, 63, 1036-1043. [CrossRef]

202. O'Connor, R.S.; Guo, L.; Ghassemi, S.; Snyder, N.W.; Worth, A.J.; Weng, L.; Kam, Y.; Philipson, B.; Trefely, S.; Nunez-Cruz, S.; et al. The CPT1a inhibitor, etomoxir induces severe oxidative stress at commonly used concentrations. Sci. Rep. 2018, 8, 6289. [CrossRef] [PubMed]

203. Lee, L.; Campbell, R.; Scheuermann-Freestone, M.; Taylor, R.; Gunaruwan, P.; Williams, L.; Ashrafian, H.; Horowitz, J.; Fraser, A.G.; Clarke, K.; et al. Metabolic modulation with perhexiline in chronic heart failureA randomized, controlled trial of short-term use of a novel treatment. Circulation 2005, 112, 3280-3288. [CrossRef] [PubMed]

204. Holubarsch, C.J.F.; Rohrbach, M.; Karrasch, M.; Boehm, E.; Polonski, L.; Ponikowski, P.; Rhein, S. A double-blind randomized multicentre clinical trial to evaluate the efficacy and safety of two doses of etomoxir in comparison with placebo in patients with moderate congestive heart failure: The ERGO (etomoxir for the recovery of glucose oxidation) study. Clin. Sci. 2007, 113, 205-212. [CrossRef] [PubMed] 
205. Abozguia, K.; Elliott, P.; McKenna, W.J.; Phan, T.T.; Nallur-Shivu, G.; Ahmed, I.; Maher, A.R.; Kaur, K.; Taylor, J.; Henning, A.; et al. Metabolic Modulator Perhexiline Corrects Energy Deficiency and Improves Exercise Capacity in Symptomatic Hypertrophic Cardiomyopathy. Circulation 2010, 122, 1562-1569. [CrossRef] [PubMed]

206. Boros, D.; Thompson, J.; Larson, D.F. Adenosine regulation of the immune response initiated by ischemia reperfusion injury. Perfusion 2016, 31, 103-110. [CrossRef] [PubMed]

207. Borea, P.A.; Varani, K.; Vincenzi, F.; Baraldi, P.G.; Tabrizi, M.A.; Merighi, S.; Gessi, S. The A3 adenosine receptor: History and perspectives. Pharmacol. Rev. 2015, 67, 74-102. [CrossRef] [PubMed]

208. Paez, D.T.; Garces, M.; Calabró, V.; Bin, E.P.; D’annunzio, V.; Del Mauro, J.; Marchini, T.; Höcht, C.; Evelson, P.; Gelpi, R.J.; et al. Adenosine A1 receptors and mitochondria: Targets of remote ischemic preconditioning. Am. J. Physiol. Circ. Physiol. 2019, 316, H743-H750. [CrossRef]

209. Ahmad, A.; Ahmad, S.; Glover, L.; Miller, S.M.; Shannon, J.M.; Guo, X.; Franklin, W.A.; Bridges, J.P.; Schaack, J.B.; Colgan, S.P.; et al. Adenosine A2A receptor is a unique angiogenic target of HIF-2alpha in pulmonary endothelial cells. Proc. Natl. Acad. Sci. USA 2009, 106, 10684-10689. [CrossRef]

210. Cao, J.; Lin, H.; Li, W.; Dong, Z.; Shi, Y.; Zhang, X.; Xiao, R. Ischemia postconditioning protects dermal microvascular endothelial cells of rabbit epigastric skin flaps against apoptosis via adenosine A2a receptors. J. Plast. Surg. Hand Surg. 2019, 53, 76-82. [CrossRef]

211. Mehaffey, J.H.; Money, D.; Charles, E.J.; Schubert, S.; Piñeros, A.F.; Wu, D.; Bontha, S.V.; Hawkins, R.; Teman, N.R.; Laubach, V.E.; et al. Adenosine 2A Receptor Activation Attenuates Ischemia Reperfusion Injury During Extracorporeal Cardiopulmonary Resuscitation. Ann. Surg. 2019, 269, 1176-1183. [CrossRef]

212. Chen, J.F.; Huang, Z.; Ma, J.; Zhu, J.; Moratalla, R.; Standaert, D.; Moskowitz, M.A.; Fink, J.S.; Schwarzschild, M.A. A(2A) adenosine receptor deficiency attenuates brain injury induced by transient focal ischemia in mice. J. Neurosci. 1999, 19, 9192-9200. [CrossRef] [PubMed]

213. Gui, L.; Duan, W.; Tian, H.; Li, C.; Zhu, J.; Chen, J.-F.; Zheng, J. Adenosine A2A receptor deficiency reduces striatal glutamate outflow and attenuates brain injury induced by transient focal cerebral ischemia in mice. Brain Res. 2009, 1297, 185-193. [CrossRef] [PubMed]

214. Atef, R.M.; Agha, A.M.; Abdel-Rhaman, A.A.; Nassar, N.N. The Ying and Yang of Adenosine A1 and A2A Receptors on ERK1/2 Activation in a Rat Model of Global Cerebral Ischemia Reperfusion Injury. Mol. Neurobiol. 2018, 55, 1284-1298. [CrossRef] [PubMed]

215. Mohamed, R.A.; Agha, A.M.; Nassar, N.N. SCH58261 the selective adenosine A(2A) receptor blocker modulates ischemia reperfusion injury following bilateral carotid occlusion: Role of inflammatory mediators. Neurochem. Res. 2012, 37, 538-547. [CrossRef] [PubMed]

216. Mohamed, R.; Agha, A.; Abdel-Rahman, A.; Nassar, N. Role of adenosine A2A receptor in cerebral ischemia reperfusion injury: Signaling to phosphorylated extracellular signal-regulated protein kinase (pERK1/2). Neuroscience 2016, 314, 145-159. [CrossRef]

217. Huerter, M.E.; Sharma, A.K.; Zhao, Y.; Charles, E.J.; Kron, I.L.; Laubach, V.E. Attenuation of Pulmonary Ischemia-Reperfusion Injury by Adenosine A2B Receptor Antagonism. Ann. Thorac. Surg. 2016, 102, 385-393. [CrossRef] [PubMed]

218. Wan, T.C.; Tampo, A.; Kwok, W.-M.; Auchampach, J.A. Ability of CP-532,903 to protect mouse hearts from ischemia/reperfusion injury is dependent on expression of A3 adenosine receptors in cardiomyoyctes. Biochem. Pharmacol. 2019, 163, 21-31. [CrossRef]

219. Ohana, G.; Cohen, S.; Rath-Wolfson, L.; Fishman, P. A3 adenosine receptor agonist, CF102, protects against hepatic ischemia/reperfusion injury following partial hepatectomy. Mol. Med. Rep. 2016, 14, 4335-4341. [CrossRef]

220. Montaner, J.; Ramiro, L.; Simats, A.; Hernández-Guillamon, M.; Delgado, P.; Bustamante, A.; Rosell, A. Matrix metalloproteinases and ADAMs in stroke. Cell. Mol. Life Sci. 2019, 76, 3117-3140. [CrossRef]

221. Bell, R.M.; Kunuthur, S.P.; Hendry, C.; Bruce-Hickman, D.; Davidson, S.; Yellon, D.M. Matrix metalloproteinase inhibition protects CyPD knockout mice independently of RISK/mPTP signalling: A parallel pathway to protection. Basic Res. Cardiol. 2013, 108, 331. [CrossRef]

222. Daly, M.C.; Atkinson, S.J.; Varisco, B.M.; Klingbeil, L.; Hake, P.; Lahni, P.; Piraino, G.; Wu, D.; Hogan, S.P.; Zingarelli, B.; et al. Role of matrix metalloproteinase- 8 as a mediator of injury in intestinal ischemia and reperfusion. FASEB J. 2016, 30, 3453-3460. [CrossRef] [PubMed] 
223. Wang, X.D.; Maretti-Mira, A.C.; Wang, L.; DeLeve, L.D. Liver-Selective MMP-9 Inhibition in the Rat Eliminates Ischemia-Reperfusion Injury and Accelerates Liver Regeneration. Hepatology 2019, 69, 314-328. [CrossRef] [PubMed]

224. Baghirova, S.; Hughes, B.G.; Poirier, M.; Kondo, M.Y.; Schulz, R. Nuclear matrix metalloproteinase-2 in the cardiomyocyte and the ischemic-reperfused heart. J. Mol. Cell. Cardiol. 2016, 94, 153-161. [CrossRef] [PubMed]

225. Sarkar, S.; Mukherjee, A.; Das, N.; Swarnakar, S. Protective roles of nanomelatonin in cerebral ischemiareperfusion of aged brain: Matrixmetalloproteinases as regulators. Exp. Gerontol. 2017, 92, 13-22. [CrossRef] [PubMed]

226. Cortes, A.L.; Gonsalez, S.R.; Rioja, L.S.; Oliveira, S.S.C.; Santos, A.L.S.; Prieto, M.C.; Melo, P.A.; Lara, L.S. Protective outcomes of low-dose doxycycline on renal function of Wistar rats subjected to acute ischemia/ reperfusion injury. Biochim. Biophys. Acta Mol. Basis Dis. 2018, 1864, 102-114. [CrossRef] [PubMed]

227. Naoumov, N.V. Cyclophilin inhibition as potential therapy for liver diseases. J. Hepatol. 2014, 61, 1166-1174. [CrossRef] [PubMed]

228. Bernardi, P.; Di Lisa, F. The mitochondrial permeability transition pore: Molecular nature and role as a target in cardioprotection. J. Mol. Cell. Cardiol. 2015, 78, 100-106. [CrossRef] [PubMed]

229. Ikeda, G.; Matoba, T.; Nakano, Y.; Nagaoka, K.; Ishikita, A.; Nakano, K.; Funamoto, D.; Sunagawa, K.; Egashira, K. Nanoparticle-Mediated Targeting of Cyclosporine A Enhances Cardioprotection Against Ischemia-Reperfusion Injury Through Inhibition of Mitochondrial Permeability Transition Pore Opening. Sci. Rep. 2016, 6, 20467. [CrossRef] [PubMed]

230. Piot, C.; Croisille, P.; Staat, P.; Thibault, H.; Rioufol, G.; Mewton, N.; Elbelghiti, R.; Cung, T.T.; Bonnefoy, E.; Angoulvant, D.; et al. Effect of cyclosporine on reperfusion injury in acute myocardial infarction. N. Engl. J. Med. 2008, 359, 473-481. [CrossRef] [PubMed]

231. Brown, D.A.; Perry, J.B.; Allen, M.E.; Sabbah, H.N.; Stauffer, B.L.; Shaikh, S.R.; Cleland, J.G.; Colucci, W.S.; Butler, J.; Voors, A.A.; et al. Expert consensus document: Mitochondrial function as a therapeutic target in heart failure. Nat. Rev. Cardiol. 2017, 14, 238-250. [CrossRef] [PubMed]

232. Ottani, F.; Latini, R.; Staszewsky, L.; La Vecchia, L.; Locuratolo, N.; Sicuro, M.; Masson, S.; Barlera, S.; Milani, V.; Lombardi, M.; et al. Cyclosporine A in Reperfused Myocardial Infarction: The Multicenter, Controlled, Open-Label CYCLE Trial. J. Am. Coll. Cardiol. 2016, 67, 365-374. [CrossRef] [PubMed]

233. Fakharnia, F.; Khodagholi, F.; Dargahi, L.; Ahmadiani, A. Prevention of Cyclophilin D-Mediated mPTP Opening Using Cyclosporine-A Alleviates the Elevation of Necroptosis, Autophagy and Apoptosis-Related Markers Following Global Cerebral Ischemia-Reperfusion. J. Mol. Neurosci. 2017, 61, 52-60. [CrossRef] [PubMed]

234. Hausenloy, D.J.; Duchen, M.R.; Yellon, D.M. Inhibiting mitochondrial permeability transition pore opening at reperfusion protects against ischaemia-reperfusion injury. Cardiovasc. Res. 2003, 60, 617-625. [CrossRef] [PubMed]

235. Paeshuyse, J.; Kaul, A.; De Clercq, E.; Rosenwirth, B.; Dumont, J.M.; Scalfaro, P.; Bartenschlager, R.; Neyts, J. The non-immunosuppressive cyclosporin DEBIO-025 is a potent inhibitor of hepatitis $\mathrm{C}$ virus replication in vitro. Hepatology 2006, 43, 761-770. [CrossRef] [PubMed]

236. Coelmont, L.; Kaptein, S.; Paeshuyse, J.; Vliegen, I.; Dumont, J.M.; Vuagniaux, G.; Neyts, J. Debio 025, a Cyclophilin Binding Molecule, Is Highly Efficient in Clearing Hepatitis C Virus (HCV) Replicon-Containing Cells When Used Alone or in Combination with Specifically Targeted Antiviral Therapy for HCV (STAT-C) Inhibitors. Antimicrob. Agents Chemother. 2009, 53, 967-976. [CrossRef] [PubMed]

237. Reutenauer, J.; Dorchies, O.M.; Patthey-Vuadens, O.; Vuagniaux, G.; Ruegg, U.T. Investigation of Debio 025, a cyclophilin inhibitor, in the dystrophic mdx mouse, a model for Duchenne muscular dystrophy. Br. J. Pharmacol. 2008, 155, 574-584. [CrossRef]

238. Gomez, L.; Thibault, H.; Gharib, A.; Dumont, J.-M.; Vuagniaux, G.; Scalfaro, P.; Derumeaux, G.; Ovize, M. Inhibition of mitochondrial permeability transition improves functional recovery and reduces mortality following acute myocardial infarction in mice. Am. J. Physiol. Circ. Physiol. 2007, 293, H1654-H1661. [CrossRef]

239. Rosenwirth, B.; Billich, A.; Datema, R.; Donatsch, P.; Hammerschmid, F.; Harrison, R.; Hiestand, P.; Jaksche, H.; Mayer, P.; Peichl, P. Inhibition of human immunodeficiency virus type 1 replication by SDZ NIM 811, a nonimmunosuppressive cyclosporine analog. Antimicrob. Agents Chemother. 1994, 38, 1763-1772. [CrossRef] 
240. Argaud, L.; Gateauroesch, O.; Muntean, D.; Chalabreysse, L.; Loufouat, J.; Robert, D.; Ovize, M. Specific inhibition of the mitochondrial permeability transition prevents lethal reperfusion injury. J. Mol. Cell. Cardiol. 2005, 38, 367-374. [CrossRef]

241. Readnower, R.D.; Pandya, J.D.; McEwen, M.L.; Pauly, J.R.; Springer, J.E.; Sullivan, P.G. Post-Injury Administration of the Mitochondrial Permeability Transition Pore Inhibitor, NIM811, Is Neuroprotective and Improves Cognition after Traumatic Brain Injury in Rats. J. Neurotrauma 2011, 28, 1845-1853. [CrossRef]

242. Theruvath, T.P.; Zhong, Z.; Pediaditakis, P.; Ramshesh, V.K.; Currin, R.T.; Tikunov, A.; Holmuhamedov, E.; Lemasters, J.J. Minocycline and N-methyl-4-isoleucine cyclosporin (NIM811) mitigate storage/reperfusion injury after rat liver transplantation through suppression of the mitochondrial permeability transition. Hepatology 2008, 47, 236-246. [CrossRef] [PubMed]

243. Shimizu, S.; Saito, M.; Kinoshita, Y.; Ohmasa, F.; Dimitriadis, F.; Shomori, K.; Hayashi, A.; Satoh, K. Nicorandil ameliorates ischaemia-reperfusion injury in the rat kidney. Br. J. Pharmacol. 2011, 163, 272-282. [CrossRef]

244. Pithadia, A.B.; Panchal, S.S.; Patel, D.J. Neuroprotective effects of potassium channel openers on cerebral ischemia-reperfusion injury in diabetic rats. Bull. Fac. Pharm. Cairo Univ. 2017, 55, 95-100. [CrossRef]

245. Coetzee, W.A. Multiplicity of effectors of the cardioprotective agent, diazoxide. Pharmacol. Ther. 2013, 140, 167-175. [CrossRef] [PubMed]

246. Yamanaka, K.; Eldeiry, M.; Aftab, M.; Ryan, T.J.; Roda, G.; Meng, X.; Weyant, M.J.; Cleveland, J.C.; Fullerton, D.A.; Reece, T.B. Pretreatment with Diazoxide Attenuates Spinal Cord Ischemia-Reperfusion Injury Through Signaling Transducer and Activator of Transcription 3 Pathway. Ann. Thorac. Surg. 2019, 107, 733-739. [CrossRef] [PubMed]

247. Yamanaka, K.; Eldeiry, M.; Aftab, M.; Mares, J.; Ryan, T.J.; Meng, X.; Weyant, M.J.; Cleveland, J.C.; Fullerton, D.A.; Reece, T.B. Optimized induction of beta common receptor enhances the neuroprotective function of erythropoietin in spinal cord ischemic injury. J. Thorac. Cardiovasc. Surg. 2018, 155, 2505-2516. [CrossRef]

248. Dourado, S.F.D.M.; Barbeiro, D.F.; Koike, M.K.; Barbeiro, H.V.; Da Silva, F.P.; Machado, M.C.C. Diazoxide reduces local and remote organ damage in a rat model of intestinal ischemia reperfusion. J. Surg. Res. 2018, 225, 118-124. [CrossRef]

249. Lesnefsky, E.J.; Chen, Q.; Moghaddas, S.; Hassan, M.O.; Tandler, B.; Hoppel, C.L. Blockade of Electron Transport during Ischemia Protects Cardiac Mitochondria. J. Boil. Chem. 2004, 279, 47961-47967. [CrossRef]

250. Chen, Q.; Hoppel, C.L.; Lesnefsky, E.J. Blockade of electron transport before cardiac ischemia with the reversible inhibitor amobarbital protects rat heart mitochondria. J. Pharmacol. Exp. Ther. 2006, 316, 200-207. [CrossRef]

251. Chance, B.; Williams, G.R.; Hollunger, G. Inhibition of electron and energy transfer in mitochondria. I. Effects of Amytal, thiopental, rotenone, progesterone, and methylene glycol. J. Boil. Chem. 1963, 238, 418-431.

252. Zhang, W.; Sha, Y.; Wei, K.; Wu, C.; Ding, D.; Yang, Y.; Zhu, C.; Zhang, Y.; Ding, G.; Zhang, A.; et al. Rotenone ameliorates chronic renal injury caused by acute ischemia/reperfusion. Oncotarget 2018, 9, 24199-24208. [CrossRef] [PubMed]

253. Boylston, J.A.; Sun, J.; Chen, Y.; Gucek, M.; Sack, M.N.; Murphy, E. Characterization of the cardiac succinylome and its role in ischemia-reperfusion injury. J. Mol. Cell. Cardiol. 2015, 88, 73-81. [CrossRef] [PubMed]

254. Chandrika, B.B.; Yang, C.; Ou, Y.; Feng, X.K.; Muhoza, D.; Holmes, A.F.; Theus, S.; Deshmukh, S.; Haun, R.S.; Kaushal, G.P. Endoplasmic Reticulum Stress-Induced Autophagy Provides Cytoprotection from Chemical Hypoxia and Oxidant Injury and Ameliorates Renal Ischemia-Reperfusion Injury. PLoS ONE 2015, 10, e0140025. [CrossRef] [PubMed]

255. Kimura, H.; Shibuya, N.; Kimura, Y. Hydrogen Sulfide Is a Signaling Molecule and a Cytoprotectant. Antioxid. Redox Signal. 2012, 17, 45-57. [CrossRef] [PubMed]

256. Karwi, Q.G.; Bice, J.S.; Baxter, G.F. Pre- and postconditioning the heart with hydrogen sulfide (H2S) against ischemia/reperfusion injury in vivo: A systematic review and meta-analysis. Basic Res. Cardiol. 2018, 113, 6. [CrossRef] [PubMed]

257. Zhao, Y.; Biggs, T.D.; Xian, M. Hydrogen sulfide (H2S) releasing agents: Chemistry and biological applications. Chem. Commun. 2014, 50, 11788-11805. [CrossRef] [PubMed]

258. Li, L.; Whiteman, M.; Guan, Y.Y.; Neo, K.L.; Cheng, Y.; Lee, S.W.; Zhao, Y.; Baskar, R.; Tan, C.-H.; Moore, P.K. Characterization of a Novel, Water-Soluble Hydrogen Sulfide-Releasing Molecule (GYY4137): New Insights Into the Biology of Hydrogen Sulfide. Circulation 2008, 117, 2351-2360. [CrossRef] [PubMed] 
259. Donnarumma, E.; Ali, M.J.; Rushing, A.M.; Scarborough, A.L.; Bradley, J.M.; Organ, C.L.; Islam, K.N.; Polhemus, D.J.; Evangelista, S.; Cirino, G.; et al. Zofenopril Protects Against Myocardial Ischemia-Reperfusion Injury by Increasing Nitric Oxide and Hydrogen Sulfide Bioavailability. J. Am. Heart Assoc. 2016, 5, 7. [CrossRef] [PubMed]

260. Kang, J.; Li, Z.; Organ, C.L.; Park, C.-M.; Yang, C.-T.; Pacheco, A.; Wang, D.; Lefer, D.J.; Xian, M. pH-Controlled Hydrogen Sulfide Release for Myocardial Ischemia-Reperfusion Injury. J. Am. Chem. Soc. 2016, 138, 6336-6339. [CrossRef]

261. Karwi, Q.G.; Bornbaum, J.; Boengler, K.; Torregrossa, R.; Whiteman, M.; Wood, M.E.; Schulz, R.; Baxter, G.F. AP39, a mitochondria-targeting hydrogen sulfide (H2S) donor, protects against myocardial reperfusion injury independently of salvage kinase signalling. Br. J. Pharmacol. 2017, 174, 287-301. [CrossRef]

262. Ikeda, K.; Marutani, E.; Hirai, S.; Wood, M.E.; Whiteman, M.; Ichinose, F. Mitochondria-targeted hydrogen sulfide donor AP39 improves neurological outcomes after cardiac arrest in mice. Nitric Oxide 2015, 49, 90-96. [CrossRef] [PubMed]

263. Ahmad, A.; Oláh, G.; Szczesny, B.; Wood, M.E.; Whiteman, M.; Szabó, C. AP39, A Mitochondrially Targeted Hydrogen Sulfide Donor, Exerts Protective Effects in Renal Epithelial Cells Subjected to Oxidative Stress in Vitro and in Acute Renal Injury in Vivo. Shock 2016, 45, 88-97. [CrossRef] [PubMed]

264. Narayanan, B.A.; Narayanan, N.K.; Re, G.G.; Nixon, D.W. Differential expression of genes induced by resveratrol in LNCaP cells: P53-mediated molecular targets. Int. J. Cancer 2003, 104, 204-212. [CrossRef] [PubMed]

265. Gross, E.R. Ligand triggers of classical preconditioning and postconditioning. Cardiovasc. Res. 2006, 70, $212-221$. [CrossRef] [PubMed]

266. Zhao, L.; Donaldson, C.J.; Smith, G.W.; Vale, W.W. The Structures of the Mouse and Human Urocortin Genes (Ucn and UCN). Genomics 1998, 50, 23-33. [CrossRef] [PubMed]

267. Baxter, G.F.; Mocanu, M.M.; Brar, B.K.; Latchman, D.S.; Yellon, D.M. Cardioprotective effects of transforming growth factor-beta1 during early reoxygenation or reperfusion are mediated by p42/p44 MAPK. J. Cardiovasc. Pharmacol. 2001, 38, 930-939. [CrossRef] [PubMed]

268. Malhotra, R.; Valuckaite, V.; Staron, M.L.; Theccanat, T.; D'Souza, K.M.; Alverdy, J.C.; Akhter, S.A. High-molecular-weight polyethylene glycol protects cardiac myocytes from hypoxia- and reoxygenation-induced cell death and preserves ventricular function. Am. J. Physiol. Circ. Physiol. 2011, 300, H1733-H1742. [CrossRef] [PubMed]

269. Pasut, G.; Panisello, A.; Folch-Puy, E.; Lopez, A.; Castro-Benítez, C.; Calvo, M.; Carbonell, T.; García-Gil, A.; Adam, R.; Roselló-Catafau, J. Polyethylene glycols: An effective strategy for limiting liver ischemia reperfusion injury. World J. Gastroenterol. 2016, 22, 6501-6508. [CrossRef] [PubMed]

270. Bejaoui, M.; Pantazi, E.; Folch-Puy, E.; Panisello, A.; Calvo, M.; Pasut, G.; Rimola, A.; Navasa, M.; Adam, R.; Rosello-Catafau, J. Protective Effect of Intravenous High Molecular Weight Polyethylene Glycol on Fatty Liver Preservation. Biomed. Res. Int. 2015, 2015, 794287. [CrossRef]

271. Abuchowski, A.; Van Es, T.; Palczuk, N.C.; Davis, F.F. Alteration of immunological properties of bovine serum albumin by covalent attachment of polyethylene glycol. J. Boil. Chem. 1977, 252, 3578-3581.

272. Lopez, A.; Panisello-Rosello, A.; Castro-Benitez, C.; Adam, R. Glycocalyx Preservation and NO Production in Fatty Livers-The Protective Role of High Molecular Polyethylene Glycol in Cold Ischemia Injury. Int. J. Mol. Sci. 2018, 19, 2375. [CrossRef] [PubMed]

273. Skyschally, A.; Gres, P.; Hoffmann, S.; Haude, M.; Erbel, R.; Schulz, R.; Heusch, G. Bidirectional role of tumor necrosis factor-alpha in coronary microembolization-Progressive contractile dysfunction versus delayed protection against infarction. Circ. Res. 2007, 100, 140-146. [CrossRef] [PubMed]

274. Schulz, R.; Heusch, G. Tumor necrosis factor-alpha and its receptors 1 and 2: Yin and Yang in myocardial infarction? Circulation 2009, 119, 1355-1357. [CrossRef] [PubMed]

275. Ward-Kavanagh, L.K.; Lin, W.W.; Šedý, J.R.; Ware, C.F.; Šedý, J.S. The TNF Receptor Superfamily in Co-stimulating and Co-inhibitory Responses. Immunity 2016, 44, 1005-1019. [CrossRef] [PubMed]

276. Shohami, E. Dual role of tumor necrosis factor alpha in brain injury. Cytokine Growth Factor Rev. 1999, 10, 119-130. [CrossRef]

277. Flaherty, M.P.; Guo, Y.; Tiwari, S.; Rezazadeh, A.; Hunt, G.; Sanganalmath, S.K.; Tang, X.-L.; Bolli, R.; Dawn, B. The role of TNF-alpha receptors p55 and p75 in acute myocardial ischemia/reperfusion injury and late preconditioning. J. Mol. Cell. Cardiol. 2008, 45, 735-741. [CrossRef] [PubMed] 
278. Shibata, R.; Sato, K.; Pimentel, D.R.; Takemura, Y.; Kihara, S.; Ohashi, K.; Funahashi, T.; Ouchi, N.; Walsh, K. Adiponectin protects against myocardial ischemia-reperfusion injury through AMPK- and COX-2-dependent mechanisms. Nat. Med. 2005, 11, 1096-1103. [CrossRef]

279. Bauche, I.B.; El Mkadem, S.A.; Pottier, A.-M.; Senou, M.; Many, M.-C.; Rezsöhazy, R.; Penicaud, L.; Maeda, N.; Funahashi, T.; Brichard, S.M. Overexpression of Adiponectin Targeted to Adipose Tissue in Transgenic Mice: Impaired Adipocyte Differentiation. Endocrinology 2007, 148, 1539-1549. [CrossRef]

280. Gao, C.; Liu, Y.; Yu, Q.; Yang, Q.; Li, B.; Sun, L.; Yan, W.; Cai, X.; Gao, E.; Xiong, L.; et al. TNF-alpha antagonism ameliorates myocardial ischemia-reperfusion injury in mice by upregulating adiponectin. Am. J. Physiol. Heart Circ. Physiol. 2015, 308, H1583-H1591. [CrossRef]

281. Tasdemir, C.; Tasdemir, S.; Vardi, N.; Ates, B.; Parlakpinar, H.; Kati, B.; Karaaslan, M.G.; Acet, A. Protective Effect of Infliximab on Ischemia/Reperfusion-Induced Damage in Rat Kidney. Ren. Fail. 2012, 34, 1144-1149. [CrossRef]

282. Nagata, Y.; Fujimoto, M.; Nakamura, K.; Isoyama, N.; Matsumura, M.; Fujikawa, K.; Uchiyama, K.; Takaki, E.; Takii, R.; Nakai, A.; et al. Anti-TNF-alpha Agent Infliximab and Splenectomy Are Protective Against Renal Ischemia-Reperfusion Injury. Transplantation 2016, 100, 1675-1682. [CrossRef] [PubMed]

283. Hiroyoshi, T.; Tsuchida, M.; Uchiyama, K.; Fujikawa, K.; Komatsu, T.; Kanaoka, Y.; Matsuyama, H. Splenectomy protects the kidneys against ischemic reperfusion injury in the rat. Transpl. Immunol. 2012, 27, 8-11. [CrossRef] [PubMed]

284. Agarwal, B.; Dash, R.K.; Stowe, D.F.; Bosnjak, Z.J.; Camara, A.K.S. Isoflurane modulates cardiac mitochondrial bioenergetics by selectively attenuating respiratory complexes. Biochim. Biophys. Acta BBA Bioenerg. 2014, 1837, 354-365. [CrossRef] [PubMed]

285. Zhang, M.; Kass, D.A. Phosphodiesterases and cardiac cGMP: Evolving roles and controversies. Trends Pharmacol. Sci. 2011, 32, 360-365. [CrossRef] [PubMed]

286. Salloum, F.N.; Takenoshita, Y.; Ockaili, R.A.; Daoud, V.P.; Chou, E.; Yoshida, K.; Kukreja, R.C. Sildenafil and vardenafil but not nitroglycerin limit myocardial infarction through opening of mitochondrial K(ATP) channels when administered at reperfusion following ischemia in rabbits. J. Mol. Cell. Cardiol. 2007, 42, 453-458. [CrossRef] [PubMed]

287. Ebner, B.; Ebner, A.; Reetz, A.; Böhme, S.; Schauer, A.; Strasser, R.H.; Weinbrenner, C. Pharmacological postconditioning by bolus injection of phosphodiesterase- 5 inhibitors vardenafil and sildenafil. Mol. Cell. Biochem. 2013, 379, 43-49. [CrossRef] [PubMed]

288. Azevedo, I.M.; da Silva, G.V.; de Medeiros, A.S.V.C.; de Medeiros Dumaresq de Souza, A.S.V.C.; de Macêdo, R.K.A.; Medeiros, A.C. Tadalafil combined with remote ischemic preconditioning in the prevention of renal ischemia/reperfusion injury. J. Surg. Clin. Res. 2018, 9, 11-23.

289. Khatib, S.Y. The Protective Effects of Phosphodiesterase 5 Inhibitors "Sildenafil \& Ordonafil" on Ischemia-Reperfusion Injury. FASEB J. 2019, 33, 833.

290. Lee, K.H.; Lee, S.-R.; Cho, H.; Woo, J.S.; Kang, J.H.; Jeong, Y.-M.; Cheng, X.W.; Kim, W.-S.; Kim, W. Cardioprotective effects of PKG activation by soluble GC activator, BAY 60-2770, in ischemia-reperfusioninjured rat hearts. PLoS ONE 2017, 12, e0180207. [CrossRef]

291. Peralta, C.; Hotter, G.; Closa, D.; Gelpi, E.; Bulbena, O.; Roselló-Catafau, J. Protective effect of preconditioning on the injury associated to hepatic ischemia-reperfusion in the rat: Role of nitric oxide and adenosine. Hepatology 1997, 25, 934-937. [CrossRef]

292. Jakobsen, Ø.; Næsheim, T.; Aas, K.N.; Sørlie, D.; Steensrud, T. Adenosine instead of supranormal potassium in cardioplegia: It is safe, efficient, and reduces the incidence of postoperative atrial fibrillation. A randomized clinical trial. J. Thorac. Cardiovasc. Surg. 2013, 145, 812-818. [CrossRef] [PubMed]

293. Fredholm, B.B. Adenosine, an endogenous distress signal, modulates tissue damage and repair. Cell Death Differ. 2007, 14, 1315-1323. [CrossRef] [PubMed]

294. Thiel, M.; Chambers, J.D.; Chouker, A.; Fischer, S.; Zourelidis, C.; Bardenheuer, H.J.; Arfors, K.E.; Peter, K. Effect of adenosine on the expression of beta(2) integrins and L-selectin of human polymorphonuclear leukocytes in vitro. J. Leukoc. Boil. 1996, 59, 671-682. [CrossRef] [PubMed]

295. Fredholm, B.B.; IJzerman, A.P.; Jacobson, K.A.; Klotz, K.N.; Linden, J. International Union of Pharmacology. XXV. Nomenclature and classification of adenosine receptors. Pharmacol. Rev. 2001, 53, 527-552. [PubMed]

296. Evora, P.R.; Roselino, C.H.; Schiaveto, P.M. Methylene blue in anaphylactic shock. Ann. Emerg. Med. 1997, 30, 240. 
297. Evora, P.R.; Rodrigues, A.J. Methylene blue revised. J. Thorac. Cardiovasc. Surg. 2006, 131, 250-251. [CrossRef] [PubMed]

298. Evora, P.R.B.; Ribeiro, P.J.D.F.; Vicente, W.V.D.A.; Dos Reis, C.L.; Rodrigues, A.J.; Menardi, A.C.; Junior, L.A.; Évora, P.M.; Bassetto, S. Methylene blue for vasoplegic syndrome treatment in heart surgery: Fifteen years of questions, answers, doubts and certainties. Braz. J. Cardiovasc. Surg. 2009, 24, 279-288. [CrossRef]

299. Evora, P.R.B. Methylene Blue Is a Guanylate Cyclase Inhibitor That Does Not Interfere with Nitric Oxide Synthesis. Tex. Heart Inst. J. 2016, 43, 103. [CrossRef]

300. Castro-E-Silva, O.; D’Albuquerque, L.A.C.; Silveira, M.R.G.; Zorzi, P.; Liu, J.B.; Campos, D.T.Q.; Victorino, J.P.; Jordani, M.C.; Mendes, K.D.S.; Évora, P.R.B. Evaluation of the therapeutic effect of methylene blue on the liver of rats submitted to ischemia and reperfusion. Acta Cir. Bras. 2018, 33, 1043-1051. [CrossRef]

301. Albuquerque, F.P.; Laureano, E.; Jordani-Gomes, M.C.; Fina, C.F.; Vanni, C.; Mente, E.D.; Vollet Filho, J.D.; Bagnato, V.S.; Dalbuquerque, L.A.C.; Evora, P.R.B.; et al. Prophylactic Use of Laser Light and Methylene Blue on Ischemia and Liver Reperfusion Injury. Transplant. Proc. 2019, 51, 1549-1554. [CrossRef]

302. Nantais, J.; Dumbarton, T.C.; Farah, N.; Maxan, A.; Zhou, J.; Minor, S.; Lehmann, C. Impact of methylene blue in addition to norepinephrine on the intestinal microcirculation in experimental septic shock. Clin. Hemorheol. Microcirc. 2014, 58, 97-105. [PubMed]

303. Lévy, B.; Fritz, C.; Tahon, E.; Jacquot, A.; Auchet, T.; Kimmoun, A. Vasoplegia treatments: The past, the present, and the future. Crit. Care 2018, 22, 52. [CrossRef] [PubMed]

304. Barbosa Evora, P.R. Blocking soluble guanylate cyclase could be the present and future of NO/cGMP inhibition for vasoplegia treatment. Crit. Care 2018, 22, 104. [CrossRef] [PubMed]

305. Schinzel, A.C.; Takeuchi, O.; Huang, Z.; Fisher, J.K.; Zhou, Z.; Rubens, J.; Hetz, C.; Danial, N.N.; Moskowitz, M.A.; Korsmeyer, S.J. Cyclophilin D is a component of mitochondrial permeability transition and mediates neuronal cell death after focal cerebral ischemia. Proc. Natl. Acad. Sci. USA 2005, 102, 12005-12010. [CrossRef] [PubMed]

306. Kurokawa, T.; Kobayashi, H.; Nonami, T.; Harada, A.; Nakao, A.; Sugiyama, S.; Ozawa, T.; Takagi, H. Beneficial effects of cyclosporine on postischemic liver injury in rats. Transplantation 1992, 53, 308-311. [CrossRef]

307. Zhang, C.-X.; Cheng, Y.; Liu, D.-Z.; Liu, M.; Cui, H.; Zhang, B.-L.; Mei, Q.-B.; Zhou, S.-Y. Mitochondria-targeted cyclosporin a delivery system to treat myocardial ischemia reperfusion injury of rats. J. Nanobiotechnol. 2019, 17, 18. [CrossRef] [PubMed]

308. Ghaffari, S.; Kazemi, B.; Toluey, M.; Sepehrvand, N. The Effect of Prethrombolytic Cyclosporine-A Injection on Clinical Outcome of Acute Anterior ST-Elevation Myocardial Infarction. Cardiovasc. Ther. 2013, 31, E34-E39. [CrossRef]

309. Haddad, E.; McAlister, V.; Renouf, E.; Malthaner, R.; Kjaer, M.S.; Gluud, L.L. Cyclosporin versus tacrolimus for liver transplanted patients. Cochrane Database Syst. Rev. 2006. [CrossRef]

310. Webster, A.C.; Taylor, R.R.; Chapman, J.R.; Craig, J.C. Tacrolimus versus cyclosporin as primary immunosuppression for kidney transplant recipients. Cochrane Database Syst. Rev. 2005. [CrossRef]

311. Penninga, L.; Penninga, E.I.; Møller, C.H.; Iversen, M.; Steinbrüchel, D.A.; Gluud, C. Tacrolimus versus cyclosporin as primary immunosuppression for lung transplant recipients. Cochrane Database Syst. Rev. 2013. [CrossRef]

312. Parodi-Rullan, R.M.; Soto-Prado, J.; Diaz-Cordero, S.I.; Vega-Lugo, J.; Chapa-Dubocq, X.; Javadov, S. Sanglifehrin A Has No Protective Effects in Non-reperfused Myocardial Infarction: The Role of Mitochondria. FASEB J. 2018, 32, 618.

313. Sloan, R.C.; Moukdar, F.; Frasier, C.R.; Patel, H.D.; Bostian, P.A.; Lust, R.M.; Brown, D.A. Mitochondrial permeability transition in the diabetic heart: Contributions of thiol redox state and mitochondrial calcium to augmented reperfusion injury. J. Mol. Cell. Cardiol. 2012, 52, 1009-1018. [CrossRef] [PubMed]

314. Bibli, S.I.; Papapetropoulos, A.; Iliodromitis, E.K.; Daiber, A.; Randriamboavonjy, V.; Steven, S.; Brouckaert, P.; Chatzianastasiou, A.; Kypreos, K.E.; Hausenloy, D.J.; et al. Nitroglycerine limits infarct size through S-nitrosation of cyclophilin D: A novel mechanism for an old drug. Cardiovasc. Res. 2019, 115, 625-636. [CrossRef] [PubMed]

315. Roy, S.; Sileikyte, J.; Neuenswander, B.; Hedrick, M.P.; Chung, T.D.Y.; Aube, J.; Schoenen, F.J.; Forte, M.A.; Bernardi, P. N-Phenylbenzamides as Potent Inhibitors of the Mitochondrial Permeability Transition Pore. ChemMedChem 2016, 11, 283-288. [CrossRef] [PubMed] 
316. Fancelli, D.; Abate, A.; Amici, R.; Bernardi, P.; Ballarini, M.; Cappa, A.; Carenzi, G.; Colombo, A.; Contursi, C.; Di Lisa, F.; et al. Cinnamic Anilides as New Mitochondrial Permeability Transition Pore Inhibitors Endowed with Ischemia-Reperfusion Injury Protective Effect in Vivo. J. Med. Chem. 2014, 57, 5333-5347. [CrossRef] [PubMed]

317. Martin, L.J.; Fancelli, D.; Wong, M.; Niedzwiecki, M.; Ballarini, M.; Plyte, S.; Chang, Q. GNX-4728, a novel small molecule drug inhibitor of mitochondrial permeability transition, is therapeutic in a mouse model of amyotrophic lateral sclerosis. Front. Cell. Neurosci. 2014, 8, 433. [CrossRef] [PubMed]

318. Richardson, A.P.; Halestrap, A.P. Quantification of active mitochondrial permeability transition pores using GNX-4975 inhibitor titrations provides insights into molecular identity. Biochem. J. 2016, 473, 1129-1140. [CrossRef] [PubMed]

319. Roy, S.; Šileikytè, J.; Schiavone, M.; Neuenswander, B.; Argenton, F.; Aube, J.; Hedrick, M.P.; Chung, T.D.Y.; Forte, M.A.; Bernardi, P.; et al. Discovery, Synthesis, and Optimization of Diarylisoxazole-3-carboxamides as Potent Inhibitors of the Mitochondrial Permeability Transition Pore. ChemMedChem 2015, 10, 1655-1671. [CrossRef] [PubMed]

320. Schaller, S.; Paradis, S.; Ngoh, G.A.; Assaly, R.; Buisson, B.; Drouot, C.; Ostuni, M.A.; Lacapere, J.-J.; Bassissi, F.; Bordet, T.; et al. TRO40303, a New Cardioprotective Compound, Inhibits Mitochondrial Permeability Transition. J. Pharmacol. Exp. Ther. 2010, 333, 696-706. [CrossRef] [PubMed]

321. Atar, D.; Arheden, H.; Berdeaux, A.; Bonnet, J.L.; Carlsson, M.; Clemmensen, P.; Cuvier, V.; Danchin, N.; Dubois-Rande, J.L.; Engblom, H.; et al. Effect of intravenous TRO40303 as an adjunct to primary percutaneous coronary intervention for acute ST-elevation myocardial infarction: MITOCARE study results. Eur. Heart J. 2015, 36, 112-119. [CrossRef] [PubMed]

322. Butt, N.; Bache-Mathiesen, L.K.; Nordrehaug, J.E.; Tuseth, V.; Munk, P.S.; Bonarjee, V.; Hall, T.S.; Jensen, S.E.; Halvorsen, S.; Firat, H.; et al. Administration of the Mitochondrial Permeability Transition Pore Inhibitor, TRO40303, prior to Primary Percutaneous Coronary Intervention, Does Not Affect the Levels of Pro-Inflammatory Cytokines or Acute-Phase Proteins. Cardiology 2017, 138, 122-132. [CrossRef] [PubMed]

323. Miao, J.X.; Huang, Z.J.; Liu, S.; Li, X.Y.; Jia, P.Y.; Guo, Y.X.; Wu, N.; Jia, D.L. Hydroxytyrosol protects against myocardial ischemia reperfusion injury by inhibiting mitochondrial permeability transition pore opening. Exp. Ther. Med. 2019, 17, 671-678. [CrossRef] [PubMed]

324. Wojtovich, A.P.; Brookes, P.S. The endogenous mitochondrial complex II inhibitor malonate regulates mitochondrial ATP-sensitive potassium channels: Implications for ischemic preconditioning. Biochim. Biophys. Acta BBA Bioenergy 2008, 1777, 882-889. [CrossRef] [PubMed]

325. Wojtovich, A.P.; Brookes, P.S. The complex II inhibitor atpenin A5 protects against cardiac ischemia-reperfusion injury via activation of mitochondrial KATP channels. Basic Res. Cardiol. 2009, 104, 121-129. [CrossRef] [PubMed]

326. Liu, B.; Zhu, X.; Chen, C.L.; Hu, K.; Swartz, H.M.; Chen, Y.R.; He, G. Opening of the mitoKATP channel and decoupling of mitochondrial complex II and III contribute to the suppression of myocardial reperfusion hyperoxygenation. Mol. Cell. Biochem. 2010, 337, 25-38. [CrossRef] [PubMed]

327. St-Pierre, J.; Buckingham, J.A.; Roebuck, S.J.; Brand, M.D. Topology of Superoxide Production from Different Sites in the Mitochondrial Electron Transport Chain. J. Boil. Chem. 2002, 277, 44784-44790. [CrossRef] [PubMed]

328. Orr, A.L.; Vargas, L.; Turk, C.N.; Baaten, J.E.; Matzen, J.T.; Dardov, V.J.; Attle, S.J.; Li, J.; Quackenbush, D.C.; Goncalves, R.L.S.; et al. Suppressors of superoxide production from mitochondrial complex III. Nat. Methods 2015, 11, 834-836. [CrossRef]

329. Scialo, F.; Sriram, A.; Fernandez-Ayala, D.; Gubina, N.; Lohmus, M.; Nelson, G.; Logan, A.; Cooper, H.M.; Navas, P.; Enriquez, J.A.; et al. Mitochondrial ROS Produced via Reverse Electron Transport Extend Animal Lifespan. Cell Metab. 2016, 23, 725-734. [CrossRef] [PubMed]

330. Schmeisser, S.; Priebe, S.; Groth, M.; Monajembashi, S.; Hemmerich, P.; Guthke, R.; Platzer, M.; Ristow, M. Neuronal ROS signaling rather than AMPK/sirtuin-mediated energy sensing links dietary restriction to lifespan extension. Mol. Metab. 2013, 2, 92-102. [CrossRef] [PubMed]

331. De Haes, W.; Frooninckx, L.; Van Assche, R.; Smolders, A.; Depuydt, G.; Billen, J.; Braeckman, B.P.; Schoofs, L.; Temmerman, L. Metformin promotes lifespan through mitohormesis via the peroxiredoxin PRDX-2. Proc. Natl. Acad. Sci. USA 2014, 111, E2501-E2509. [CrossRef] [PubMed] 
332. Dröse, S.; Hanley, P.J.; Brandt, U. Ambivalent effects of diazoxide on mitochondrial ROS production at respiratory chain complexes I and III. Biochim. Biophys. Acta BBA Gen. Subj. 2009, 1790, 558-565. [CrossRef] [PubMed]

333. Scialò, F.; Fernández-Ayala, D.J.; Sanz, A. Role of Mitochondrial Reverse Electron Transport in ROS Signaling: Potential Roles in Health and Disease. Front. Physiol. 2017, 8, 428. [CrossRef] [PubMed]

334. Fato, R.; Bergamini, C.; Bortolus, M.; Maniero, A.L.; Leoni, S.; Ohnishi, T.; Lenaz, G. Differential effects of mitochondrial Complex I inhibitors on production of reactive oxygen species. Biochim. Biophys. Acta 2009, 1787, 384-392. [CrossRef] [PubMed]

335. Korge, P.; Calmettes, G.; Weiss, J.N. Reactive oxygen species production in cardiac mitochondria after complex I inhibition: Modulation by substrate-dependent regulation of the NADH/NAD(+) ratio. Free Radic. Biol. Med. 2016, 96, 22-33. [CrossRef] [PubMed]

336. Detaille, D.; Pasdois, P.; Sémont, A.; Dos Santos, P.; Diolez, P. An old medicine as a new drug to prevent mitochondrial complex I from producing oxygen radicals. PLoS ONE 2019, 14, e0216385. [CrossRef] [PubMed]

337. Lambert, A.J.; Brand, M.D. Inhibitors of the Quinone-binding Site Allow Rapid Superoxide Production from Mitochondrial NADH:Ubiquinone Oxidoreductase (Complex I). J. Boil. Chem. 2004, 279, 39414-39420. [CrossRef] [PubMed]

338. Lambert, A.J.; Brand, M.D. Superoxide production by NADH:ubiquinone oxidoreductase (complex I) depends on the $\mathrm{pH}$ gradient across the mitochondrial inner membrane. Biochem. J. 2004, 382, 511-517. [CrossRef]

339. Hirst, J.; King, M.S.; Pryde, K.R. The production of reactive oxygen species by complex I. Biochem. Soc. Trans. 2008, 36, 976-980. [CrossRef] [PubMed]

340. Pryde, K.R.; Hirst, J. Superoxide Is Produced by the Reduced Flavin in Mitochondrial Complex I a Single, Unified Mechanism That Applies during both Forward and Reverse Electron Transfer. J. Biol. Chem. 2011, 286, 18056-18065. [CrossRef] [PubMed]

341. Ichikawa, H.; Takagi, T.; Uchiyama, K.; Higashihara, H.; Katada, K.; Isozaki, Y.; Naito, Y.; Yoshida, N.; Yoshikawa, T. Rotenone, a mitochondrial electron transport inhibitor, ameliorates ischemia-reperfusioninduced intestinal mucosal damage in rats. Redox Rep. 2004, 9, 313-316. [CrossRef] [PubMed]

342. Sun, Y.; Zhang, Y.; Zhao, D.; Ding, G.; Huang, S.; Zhang, A.; Jia, Z. Rotenone Remarkably Attenuates Oxidative Stress, Inflammation, and Fibrosis in Chronic Obstructive Uropathy. Mediat. Inflamm. 2014, 2014, 670106. [CrossRef] [PubMed]

343. Tanaka-Esposito, C.; Chen, Q.; Lesnefsky, E.J. Blockade of electron transport before ischemia protects mitochondria and decreases myocardial injury during reperfusion in aged rat hearts. Transl. Res. 2012, 160, 207-216. [CrossRef] [PubMed]

344. Nadtochiy, S.M.; Burwell, L.S.; Ingraham, C.A.; Spencer, C.M.; Friedman, A.E.; Pinkert, C.A.; Brookes, P.S. In vivo cardioprotection by S-nitroso-2-mercaptopropionyl glycine. J. Mol. Cell. Cardiol. 2009, 46, 960-968. [CrossRef] [PubMed]

345. Chouchani, E.T.; Methner, C.; Nadtochiy, S.M.; Logan, A.; Pell, V.R.; Ding, S.; James, A.M.; Cocheme, H.M.; Reinhold, J.; Lilley, K.S.; et al. Cardioprotection by S-nitrosation of a cysteine switch on mitochondrial complex I. Nat. Med. 2013, 19, 753-759. [CrossRef] [PubMed]

346. Mohsin, A.A.; Chen, Q.; Quan, N.; Rousselle, T.; Maceyka, M.W.; Samidurai, A.; Thompson, J.; Hu, Y.; Li, J.; Lesnefsky, E.J. Mitochondrial Complex I Inhibition by Metformin Limits Reperfusion Injury. J. Pharmacol. Exp. Ther. 2019, 369, 282-290. [CrossRef] [PubMed]

347. Gadicherla, A.K.; Stowe, D.F.; Antholine, W.E.; Yang, M.; Camara, A.K. Damage to mitochondrial complex I during cardiac ischemia reperfusion injury is reduced indirectly by anti-anginal drug ranolazine. Biochim. Biophys. Acta 2012, 1817, 419-429. [CrossRef] [PubMed]

348. Brand, M.D.; Goncalves, R.L.; Orr, A.L.; Vargas, L.; Gerencser, A.A.; Borch Jensen, M.; Wang, Y.T.; Melov, S.; Turk, C.N.; Matzen, J.T.; et al. Suppressors of Superoxide- $\mathrm{H}_{2} \mathrm{O}_{2}$ Production at Site IQ of Mitochondrial Complex I Protect against Stem Cell Hyperplasia and Ischemia-Reperfusion Injury. Cell Metab. 2016, 24, 582-592. [CrossRef]

349. Dröse, S.; Bleier, L.; Brandt, U. A Common Mechanism Links Differently Acting Complex II Inhibitors to Cardioprotection: Modulation of Mitochondrial Reactive Oxygen Species Production. Mol. Pharmacol. 2011, 79, 814-822. [CrossRef] 
350. Gutman, M.; Silamn, N. The steady state activity of succinate dehydrogenase in the presence of opposing effectors. 1. The effect of L malate and CoQH2 on the enzymic activity. Mol. Cell. Biochem. 1975, 7, 51-58. [CrossRef]

351. Zeylemaker, W.; Slater, E. The inhibition of succinate dehydrogenase by oxaloacetate. Biochim. Biophys. Acta BBA Enzym. 1967, 132, 210-212. [CrossRef]

352. Valls-Lacalle, L.; Barba, I.; Miro-Casas, E.; Alburquerque-Bejar, J.J.; Ruiz-Meana, M.; Fuertes-Agudo, M.; Rodriguez-Sinovas, A.; Garcia-Dorado, D. Succinate dehydrogenase inhibition with malonate during reperfusion reduces infarct size by preventing mitochondrial permeability transition. Cardiovasc. Res. 2016, 109, 374-384. [CrossRef] [PubMed]

353. Valls-Lacalle, L.; Barba, I.; Miró-Casas, E.; Ruiz-Meana, M.; Rodríguez-Sinovas, A.; Garcia-Dorado, D. Selective Inhibition of Succinate Dehydrogenase in Reperfused Myocardium with Intracoronary Malonate Reduces Infarct Size. Sci. Rep. 2018, 8, 2442. [CrossRef] [PubMed]

354. Merlen, G.; Raymond, V.A.; Cassim, S.; Lapierre, P.; Bilodeau, M. Oxaloacetate Protects Rat Liver from Experimental Warm Ischemia/Reperfusion Injury by Improving Cellular Energy Metabolism. Liver Transplant. 2019, 25, 627-639. [CrossRef] [PubMed]

355. Marosi, M.; Fuzik, J.; Nagy, D.; Rákos, G.; Kis, Z.; Vécsei, L.; Toldi, J.; Ruban-Matuzani, A.; Teichberg, V.I.; Farkas, T. Oxaloacetate restores the long-term potentiation impaired in rat hippocampus CA1 region by 2-vessel occlusion. Eur. J. Pharmacol. 2009, 604, 51-57. [CrossRef] [PubMed]

356. Guo, L.L.; Shestov, A.A.; Worth, A.J.; Nath, K.; Nelson, D.S.; Leeper, D.B.; Glickson, J.D.; Blair, I.A. Inhibition of Mitochondrial Complex II by the Anticancer Agent Lonidamine. J. Biol. Chem. 2016, 291, 42-57. [CrossRef]

357. Rudolph, V.; Rudolph, T.K.; Schopfer, F.J.; Bonacci, G.; Woodcock, S.R.; Cole, M.P.; Baker, P.R.; Ramani, R.; Freeman, B.A. Endogenous generation and protective effects of nitro-fatty acids in a murine model of focal cardiac ischaemia and reperfusion. Cardiovasc. Res. 2010, 85, 155-166. [CrossRef]

358. Koenitzer, J.R.; Bonacci, G.; Woodcock, S.R.; Chen, C.S.; Cantu-Medellin, N.; Kelley, E.E.; Schopfer, F.J. Fatty acid nitroalkenes induce resistance to ischemic cardiac injury by modulating mitochondrial respiration at complex II. Redox Biol. 2016, 8, 1-10. [CrossRef]

359. Khoo, N.K.H.; Li, L.; Salvatore, S.R.; Schopfer, F.J.; Freeman, B.A. Electrophilic fatty acid nitroalkenes regulate Nrf2 and NF-kappaB signaling: A medicinal chemistry investigation of structure-function relationships. Sci. Rep. 2018, 8, 2295. [CrossRef]

360. Nadtochiy, S.M.; Zhu, Q.M.; Urciuoli, W.; Rafikov, R.; Black, S.M.; Brookes, P.S. Nitroalkenes confer acute cardioprotection via adenine nucleotide translocase 1. J. Biol. Chem. 2012, 287, 3573-3580. [CrossRef]

361. Nadtochiy, S.M.; Baker, P.R.; Freeman, B.A.; Brookes, P.S. Mitochondrial nitroalkene formation and mild uncoupling in ischaemic preconditioning: Implications for cardioprotection. Cardiovasc. Res. 2009, 82, 333-340. [CrossRef]

362. Nadtochiy, S.M.; Madukwe, J.; Hagen, F.K.; Brookes, P.S. Mitochondrially targeted nitro-linoleate: A new tool for the study of cardioprotection. Br. J. Pharmacol. 2014, 171, 2091-2098. [CrossRef] [PubMed]

363. Hoek, T.L.V.; Becker, L.B.; Shao, Z.; Li, C.; Schumacker, P.T. Reactive Oxygen Species Released from Mitochondria during Brief Hypoxia Induce Preconditioning in Cardiomyocytes. J. Boil. Chem. 1998, 273, 18092-18098. [CrossRef] [PubMed]

364. Oldenburg, O.; Cohen, M.V.; Downey, J.M. Mitochondrial K(ATP) channels in preconditioning. J. Mol. Cell. Cardiol. 2003, 35, 569-575. [CrossRef]

365. Bleier, L.; Drose, S. Superoxide generation by complex III: From mechanistic rationales to functional consequences. Biochim. Biophys. Acta 2013, 1827, 1320-1331. [CrossRef]

366. Halestrap, A.P.; Clarke, S.J.; Khaliulin, I. The role of mitochondria in protection of the heart by preconditioning. Biochim. Biophys. Acta BBA Bioenergy 2007, 1767, 1007-1031. [CrossRef] [PubMed]

367. Guzy, R.D.; Mack, M.M.; Schumacker, P.T. Mitochondrial Complex III is Required for Hypoxia-Induced ROS Production and Gene Transcription in Yeast. Antioxid. Redox Signal. 2007, 9, 1317-1328. [CrossRef]

368. Klimova, T.; Chandel, N.S. Mitochondrial complex III regulates hypoxic activation of HIF. Cell Death Differ. 2008, 15, 660-666. [CrossRef] [PubMed]

369. Chandel, N.S.; McClintock, D.S.; Feliciano, C.E.; Wood, T.M.; Melendez, J.A.; Rodriguez, A.M.; Schumacker, P.T. Reactive oxygen species generated at mitochondrial complex III stabilize hypoxia-inducible factor-1 alpha during hypoxia-A mechanism of O-2 sensing. J. Biol. Chem. 2000, 275, 25130-25138. [CrossRef] 
370. Stepanova, A.; Konrad, C.; Manfredi, G.; Springett, R.; Ten, V.; Galkin, A. The dependence of brain mitochondria reactive oxygen species production on oxygen level is linear, except when inhibited by antimycin A. J. Neurochem. 2019, 148, 731-745. [CrossRef]

371. Baur, J.A.; Chen, D.; Chini, E.N.; Chua, K.; Cohen, H.Y.; de Cabo, R.; Deng, C.; Dimmeler, S.; Gius, D.; Guarente, L.P.; et al. Dietary restriction: Standing up for sirtuins. Science 2010, 329, 1012-1013. [CrossRef]

372. Braidy, N.; Guillemin, G.J.; Mansour, H.; Chan-Ling, T.; Poljak, A.; Grant, R. Age related changes in NAD+ metabolism oxidative stress and Sirt1 activity in wistar rats. PLoS ONE 2011, 6, e19194. [CrossRef] [PubMed]

373. Porter, G.A.; Urciuoli, W.R.; Brookes, P.S.; Nadtochiy, S.M. SIRT3 deficiency exacerbates ischemia-reperfusion injury: Implication for aged hearts. Am. J. Physiol. Circ. Physiol. 2014, 306, H1602-H1609. [CrossRef] [PubMed]

374. Banks, A.S.; Kon, N.; Knight, C.; Matsumoto, M.; Gutierrez-Juarez, R.; Rossetti, L.; Gu, W.; Accili, D. SirT1 gain of function increases energy efficiency and prevents diabetes in mice. Cell Metab. 2008, 8, 333-341. [CrossRef] [PubMed]

375. Wang, Y.-H.; Li, S.-A.; Huang, C.-H.; Su, H.-H.; Chen, Y.-H.; Chang, J.T.; Huang, S.-S. Sirt1 Activation by Post-ischemic Treatment with Lumbrokinase Protects Against Myocardial Ischemia-Reperfusion Injury. Front. Pharmacol. 2018, 9, 636. [CrossRef]

376. Li, R.; Ma, X.; Song, Y.; Zhang, Y.; Xiong, W.; Li, L.; Zhou, L. Anti-colorectal cancer targets of resveratrol and biological molecular mechanism: Analyses of network pharmacology, human and experimental data. J. Cell. Biochem. 2019, 120, 11265-11273. [CrossRef] [PubMed]

377. Wu, H.; Tang, C.; Tai, L.W.; Yao, W.; Guo, P.; Hong, J.; Yang, X.; Li, X.; Jin, Z.; Ke, J.; et al. Flurbiprofen axetil attenuates cerebral ischemia/reperfusion injury by reducing inflammation in a rat model of transient global cerebral ischemia/reperfusion. Biosci. Rep. 2018, 38, 4. [CrossRef] [PubMed]

378. Weng, X.-F.; Li, S.-T.; Song, Q.; Zhu, Q.; Song, D.-D.; Qin, Z.-H.; Xie, Y. Protective Effect of Nicotinamide Adenine Dinucleotide Phosphate on Renal Ischemia-Reperfusion Injury. Kidney Blood Press. Res. 2018, 43, 651-663. [CrossRef] [PubMed]

379. Weisbrot-Lefkowitz, M.; Reuhl, K.; Perry, B.; Chan, P.H.; Inouye, M.; Mirochnitchenko, O. Overexpression of human glutathione peroxidase protects transgenic mice against focal cerebral ischemia/reperfusion damage. Mol. Brain Res. 1998, 53, 333-338. [CrossRef]

380. Beadle, R.M.; Williams, L.K.; Kuehl, M.; Bowater, S.; Abozguia, K.; Leyva, F.; Yousef, Z.; Wagenmakers, A.J.; Thies, F.; Horowitz, J.; et al. Improvement in Cardiac Energetics by Perhexiline in Heart Failure due to Dilated Cardiomyopathy. JACC Heart Fail. 2015, 3, 202-211. [CrossRef]

381. Nadtochiy, S.M.; Wang, Y.T.; Nehrke, K.; Munger, J.; Brookes, P.S. Cardioprotection by nicotinamide mononucleotide (NMN): Involvement of glycolysis and acidic pH. J. Mol. Cell. Cardiol. 2018, 121, 155-162. [CrossRef]

382. Mc Rosano, G.; Vitale, C. Metabolic Modulation of Cardiac Metabolism in Heart Failure. Card. Fail. Rev. 2018, 4, 99-103. [CrossRef] [PubMed]

383. Chong, C.-R.; Ong, G.J.; Horowitz, J.D. Emerging drugs for the treatment of angina pectoris. Expert Opin. Emerg. Drugs 2016, 21, 1-12. [CrossRef]

384. Bonora, M.; Wieckowski, M.R.; Sinclair, D.A.; Kroemer, G.; Pinton, P.; Galluzzi, L. Targeting mitochondria for cardiovascular disorders: Therapeutic potential and obstacles. Nat. Rev. Cardiol. 2019, 16, 33-55. [CrossRef] [PubMed]

385. Chen, X.; Patra, A.; Sadowska, G.B.; Stonestreet, B.S. Ischemic-Reperfusion Injury Increases Matrix Metalloproteinases and Tissue Metalloproteinase Inhibitors in Fetal Sheep Brain. Dev. Neurosci. 2018, 40, $234-245$. [CrossRef]

386. Duarte, S.; Baber, J.; Fujii, T.; Coito, A.J. Matrix metalloproteinases in liver injury, repair and fibrosis. Matrix Boil. 2015, 44, 147-156. [CrossRef] [PubMed]

387. Cerofolini, L.; Fragai, M.; Luchinat, C. Mechanism and Inhibition of Matrix Metalloproteinases. Curr. Med. Chem. 2018, 26, 2609-2633. [CrossRef] [PubMed]

388. Bao, D.-S.; Wu, Y.-K.; Wang, G.-Y.; Yang, S.-J.; Liang, G.-B.; Xie, Z.-H.; Rong, S.; Fu, S.-J. Hyperbaric Oxygenation Protects Against Ischemia-Reperfusion Injury in Transplanted Rat Kidneys by Triggering Autophagy and Inhibiting Inflammatory Response. Ann. Transplant. 2017, 22, 75-82. [CrossRef] 
389. Huchim, O.; Rivas-Sosa, F.; Rivera-Canul, N.; Mendez-Dominguez, N. 350 años de la medicina hiperbárica: Aspectos históricos, fisiopatogénicos y terapéuticos. Gac. Med. Mex. 2017, 153, 938-945. [CrossRef]

390. Fife, C.E.; Eckert, K.A.; Carter, M.J. An Update on the Appropriate Role for Hyperbaric Oxygen: Indications and Evidence. Plast. Reconstr. Surg. 2016, 138, 107S-116S. [CrossRef]

391. Tezcan, O.; Caliskan, A.; Demirtas, S.; Yavuz, C.; Kuyumcu, M.; Nergiz, Y.; Guzel, A.; Karahan, O.; Ari, S.; Soker, S.; et al. Effects of Hyperbaric Oxygen Treatment on Renal System. Iran. J. Kidney Dis. 2017, 11, 18-22.

(C) 2019 by the authors. Licensee MDPI, Basel, Switzerland. This article is an open access article distributed under the terms and conditions of the Creative Commons Attribution (CC BY) license (http://creativecommons.org/licenses/by/4.0/). 